\title{
Megaspores and Ostracods from the Rhaeto-Liassic Section in the Boring Rødby No. 1, Southern Denmark
}

\author{
By \\ Finn Bertelsen and Olaf Michelsen
}

\author{
Dansk sammendrag: \\ Megasporer og ostracoder fra Rhæt-Lias \\ afsnittet $\mathrm{i}$ boringen Rødby No. 1, Syd-Danmark
}

With 17 plates

I kommission hos

C. A. REITZELS FORLAG

KØBENHAVN 1970 
DANMARKS GEOLOGISKE UNDERSØGELSE

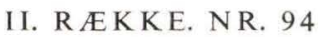

Geological Survey of Denmark. II Series. No. 94

\title{
Megaspores and Ostracods from the Rhaeto-Liassic Section in the Boring Rødby No. 1, Southern Denmark
}

\author{
By \\ Finn Bertelsen and Olaf Michelsen
}

Dansk sammendrag:

Megasporer og ostracoder fra Rhæt-Lias

afsnittet i boringen Rødby No. 1, Syd-Danmark.

With 17 plates

I kommission hos

C. A. REITZELS FORLAG

KøBENHAVN 1970 
ISBN $87 \quad 421 \quad 0605 \quad 2$ 


\section{CONTENTS}

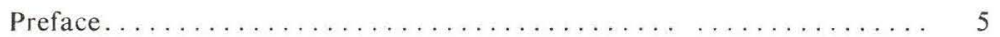

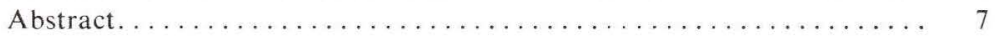

Introduction................................ 9

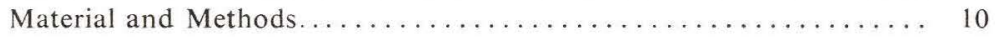

Stratigraphical investigation. . . . . . . . . . . . . . . 10

Composition of the megaspore flora ................ 10

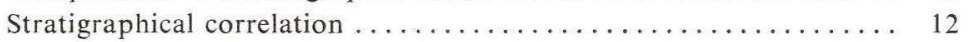

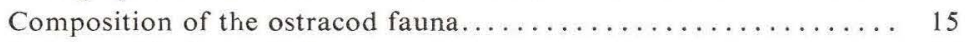

Stratigraphical correlation . . . . . . . . . . . . 16

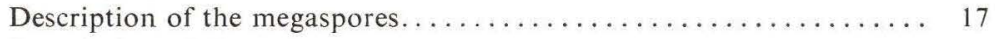

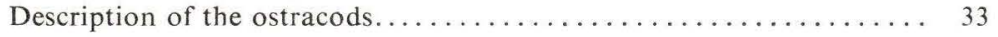

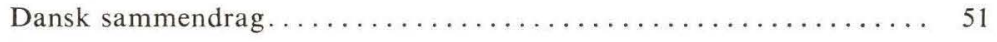

References............................ 58 


\section{PREFACE}

The present work contains a palaeontological study and a stratigraphical revision of the Rhaeto-Liassic section in the boring Rødby No. 1 based on megaspores and ostracods. FINN BERTELSEN describes the megaspores from the entire section, and OLAF MICHELSEN describes the ostracods from the Liassic part of the section. The ostracods from the Rhaetic part of the section have been registered but not described.

Mr. O. NeergaArd Rasmussen, Geol. Surv. of Denmark, was in charge of the photographic work, while Miss A. NørGAARD JENSEN, Institute of Historical Geology and Palaeontology, Copenhagen, has madethe scanning electronic micrographs. The drawings are made by Mrs. K. SørENSEN and Mrs. H. M. JørGensen in the Geol. Surv. of Denmark. The manuscript was translated into English by geophysicist S. E. HENRIKSEN and typed by Mrs. K. Sperling, both of the Geol. Survey of Denmark.

Finn Bertelsen wishes to direct a special thanks to Dr. T. MarcinKIEWICZ, Warszawa, for the opportunity to study her collection of megaspores and for the material she has sent him. The journey to Poland and the stay there was paid by CARLSEN-LANGes LegatstifTelse, Gammel Kjøgegaard, Køge.

To all of the above-mentioned helpers and to our colleagues who through discussions and comments have supported this work, we offer our most cordial thanks. 


\begin{abstract}
Megaspores and ostracods from the Rhaeto-Liassic section of the boring Rødby No. 1 are studied.

15 species of megaspores are described, of which two are new: Bacutriletes reticuliferus n. sp. and Horstisporites sp. (Type No. 5). Another one, Macrosporites cf. brasserti (STACH \& ZERNDT) is a derived carboniferous form. Two assemblage zones are defined, namely the $T$. pinguis Assemblage Zone (below, Rhaetic) and the N. hopliticus Assemblage Zone (above, Lower Lias).

10 species of ostracods from the Lias section are described, of which two are new: Procytheridea medioreticulata n. sp. and Stenestroemia ? roedbyensis n. sp., and five have open nomenclature. The ostracods from the Rhaetic are registered but not described. The O. aspinata Assemblage Zone (Lower Lias) is defined.

The Rhacto-Liassic section is divided chronostratigraphically in Middle Rhaetic, Upper Rhaetic, Lower Hettangian, Upper Hettangian, and ? Lower Sinemurian.
\end{abstract}




\section{INTRODUCTION}

The boring of Rødby No. 1 was made during the early months of 1952 . The geographical location of the borehole on the island of Lolland in the southern part of Denmark is shown in Sorgenfrei \& Buch (1964, pl. 17).

The Lias section was first time published by Nørvang (1957). In this work the contact Albian-Lias is given at 1549', while the lower boundary of the Lias is placed at $1839^{\prime}$, partly on the basis of a lithological break at that depth. In an attempt to subdivide the section, NøRVANG gives an abstract of an internal report by P. H. BAADSGAARD, who has examined the megafossils from the cores. This subdivision is here given in a shortened version:

$\begin{aligned} 1630^{\prime}-1690^{\prime} & \text { Lias, correlation unknown. } \\ 1755^{\prime} & \text { Lias Bone Bed, not correlated. } \\ 1798^{\prime}-1807^{\prime} & \text { Lias Gamma, jamesoni-ibex Zone. } \\ 1810^{\prime}-1816^{\prime} & \text { Lias Alpha. } \\ 1825^{\prime}-1827^{\prime} & \text { Lias Alpha, planorbis Zone. } \\ 1835.5^{\prime}-1837.5^{\prime} & \text { Lias, Pre-planorbis Zone. }\end{aligned}$

NøRVANG $(1957$, p. 323) has analysed the foraminifera fauna and has characterized it as extremely poor. It indicates Lias but does not form a basis for further subdivision.

In Sorgenfrei \& Buch (1964) a lithological outline of the Rhaeto-Liassic section is given. This lithological description is shown in pl. XVII. SORGENFreI \& BUCH subdivides the Lias section in accordance with P. H. BAADSGAARD's subdivision. The Rhaetic section seems to be separated on the basis of lithological features and the occurrence of megaspores "with circular fold".

The lithological profile shown in pl. XVII is drawn after LARSEN (1966, pl. XV). In his work the sedimentational development in the Danish Embayment is studied, and he has made a division of the sequence into formations. Chronostratigraphically the Fjerritslev Formation belongs to the Lias and the Ullerslev Formation to the Rhaetic.

In Rødby No. 1 the uppermost part of the profile is made up of a $1 \mathrm{~m}$ thick layer of a red-yellow-green variegated silt, which differs from the typical appearance of the Fjerritslev Formation. LARSEN assumes that this layer is a weathering horizon, presumably of post-Liassic origin.

A few pieces of cores from the Rhaeto-Liassic section of Rødby No. 1 are figured in LARSEN (1966, text-figs. 4, 5, 7, 8 and 11). 


\section{MATERIALS AND METHODS}

The interval examined is cored in its entirety. When the samples were taken they were numbered consecutively as samples $M_{1}-M_{113}$. The position of the samples in the profile is shown in pl. XVII. For the evaluation of the ostracod fauna, Mrs. I. BANG (D.G.U.) has been so kind to make available the samples I $\left(1802.3^{\prime}\right)$ and II $\left(1803.3^{\prime}\right)$. All depths given in feet in this paper are measured from the Kelly Bushing (pl. XVII).

The samples, which were 100-200 $\mathrm{g}$ in size, were after drying dispersed with gasoline and boiling water. The size fraction less than $0.1 \mathrm{~mm}$ was washed away on a sieve, whereafter possible fossils were picked out from the residue.

Very sandy samples with but small content of organic material were gravityseparated by means of $\mathrm{CCl}_{4}$, thereby facilitating the process of sorting.

Before the authors of this paper sorted out the megaspores and the ostracods, certain other fossils, such as e.g. foraminifera, were in some cases sorted out. An absolute measure of the quantitative distribution of the microfossils in the profile is therefore not given in pl. XVII. Instead the distribution in the samples of a given species must be looked for in the respective description.

Representative megaspores were first cleaned with a $40 \%$ hydrofluoric acid and then given a short ultrasonic treatment (duration $\frac{1}{2}$ minute), whereupon they were mounted on double-coated tape on 12-mm specimen holders. They were then coated with gold and thereby made ready for examination in the scanning electronic microscope. Some of the other megaspores were after the first steps in the treatment cleared in Schulzes solution and then given a short treatment in a $5 \%$ solution of $\mathrm{KOH}$, whereupon they were mounted in glycerine jelly for examination in transmitted light. The exine of one of the megaspore species was studied in thin section, which was produced by a method normally used for foraminifera tests. As grinding material was used a glass slide which by means of silicon carbide powder was given a rough surface. The megaspore was fastened to another glass slide by means of Lakeside (an artificial resin) and was then ground by means of the frosted glass with water as lubricating agent. The progress of the grinding is followed in the binocular microscope. The method seems to be usable only for spores with a thick, relatively hard exine.

\section{STRATIGRAPHICAL INVESTIGATION}

\section{Composition of the megaspore flora.}

The megaspore flora in the interval of the boring Rødby No. 1 studied comprises 15 species in all. Out of these, 12 species have been previously described from Rhaetic and Liassic deposits, while two species are new. One of these two 
is defined as a new species while the other one is only described and discussed, as the material was too scanty for erection of a new species. Finally, one megaspore, probably of carboniferous origin, has been found in the uppermost part of the interval.

The vertical distribution of the individual megaspore species in the interval examined is shown in plate XVII. The number of the spores in the individual samples is not given in this plate but in the respective descriptions.

The flora is, as plate XVII shows, grouped in two spore assemblages, which overlap in a relatively short interval corresponding to the samples $\mathrm{M}_{50}-\mathrm{M}_{52}$. The overlap in this short interval presumably indicates a corresponding, short period of transition in the spore-producing plant societies, during which time one flora was replaced by another one. A mixing of the two assemblages as a result of the conditions of sedimentation is excluded, since no corresponding mixing of the ostracod faunas is observed (cf. pl. XVII). The older one of the two megaspore assemblages comprises the following 8 previously described species:

Calamospora rhaetica (JunG) POTONIÉ

Trileites cf. pedinacron (HARRIS) POTONIÉ

Trileites pinguis (HARRIS) POTONIÉ

Maexisporites cf. misellus MARCINKIEWICZ

Verrutriletes utilis (MARCINKIEWICZ) MARC.

Bacutriletes tylotus (HARRIS) POTONIÉ

Horstisporites rexargenteus (HARRIS) POTONIÉ

Minerisporites ales (HARris) POTONIÉ

and two new ones:

Bacutriletes reticuliferus $\mathrm{n}$. $\mathrm{sp}$.

Horstisporites sp., megaspore type No. 5

Trileites pinguis (HARRIS) РОT. is the dominating and characterizing species in this assemblage, which is found in the sample interval $M_{50}-M_{103}$. In the lowermost of these samples it is, however, scantily represented. These samples are dominated by Minerisporites ales (Harris) Pot., which shows a tendency to decrease in number upward at the same time as Trileites pinguis increases in number.

Trileites cf. pedinacron (Harris) POT., Verrutriletes utilis MARCINKIEWICZ and Bacutriletes tylotus (HARRIS) POT. occur commonly in the upper samples, while the other 5 species are rare.

The megaspore-bearing samples are not evenly distributed in the abovementioned interval but group themselves in sections that are alternatingly fairly rich and poor in specimens. The following sections may be separated as spore-bearing: $\mathrm{M}_{50}-\mathrm{M}_{53}, \mathrm{M}_{61}-\mathrm{M}_{71}, \mathrm{M}_{75}, \mathrm{M}_{95}$, and $\mathrm{M}_{100}-\mathrm{M}_{103}$, whereas the other sections contain very few or no megaspores. 
The megaspore assemblage is in the following called the $T$. pinguis assemblage, a name which already earlier has been used in the literature (WILL, 1969).

The younger one of the two spore assemblages comprises 4 species, all of which are known from previous descriptions:

Verrutriletes franconicus JUNG

Horstisporites areolatus (HARRIS) POTONIÉ

Horstisporites harrisi (MurRaY) POTONIÉ

Nathorstisporites hopliticus JUNG

This assemblage is in the following called the $N$. hopliticus assemblage after the dominating species. It has a vertical extent corresponding to the sample interval $\mathrm{M}_{4}-\mathrm{M}_{52}$. Nathorstisporites hopliticus JUNG is by far the most common species in all of the megaspore-bearing samples, while the specimens of the other species occur only infrequently with the exception of Verrutriletes franconicus JUNG, which occurs fairly commonly in the uppermost samples.

The sample interval $\mathbf{M}_{4}-\mathbf{M}_{49}$ contains two sections that are fairly rich in spores, namely $\mathbf{M}_{4}-\mathbf{M}_{7}$ and $\mathbf{M}_{19}-\mathbf{M}_{33}$. They are inhomogeneous as far as the frequency of specimens is concerned, in that certain of the samples are rich in spores $\left(\mathrm{M}_{4}\right.$ and $\left.\mathrm{M}_{25}\right)$ while some others contain no spores $\left(\mathrm{M}_{21}, \mathrm{M}_{24}, \mathrm{M}_{26}\right.$, $\mathrm{M}_{28}$ and $\mathrm{M}_{29}$ ). The samples outside of the two intervals named contain a few or no megaspores. In the interval $\mathrm{M}_{50}-\mathrm{M}_{52}$, which in the above discussion is included in the sections rich in spores, only a few specimens from the $N$. hopliticus assemblage were found.

It is possible, on the basis of the subdivision of the megaspore flora into two assemblages, to divide the interval studied into two assemblage zones, namely (below) the $T$. pinguis Assemblage Zone $\left(1858^{\prime}-2320^{\prime}\right)$ and (above) the $N$. hopliticus Assemblage Zone (1561'-1858'). The lower boundary of the $T$. pinguis Assemblage Zone is placed at the point where megaspores of this assemblage make their first appearance (in sample $\mathbf{M}_{103}$ ), while the upper boundary of the $N$. hopliticus Assemblage Zone is placed at the uppermost occurrence of megaspores of this assemblage (in sample $\mathrm{M}_{4}$ ).

The boundary between the two assemblage zones is placed just beneath the oldest sample containing species of the $N$. hopliticus assemblage $\left(\mathrm{M}_{52}\right)$, at a depth of $1858^{\prime}$. Thus the lower part of the N. hopliticus Assemblage Zone contain species from the $T$. pinguis assemblage ( $T$. cf. pedinacron, $T$. pinguis, $V$. utilis, B. reticuliferus and B. tylotus).

\section{Stratigraphical correlation.}

The $T$. pinguis Assemblage Zone: Those megaspore species which occur in this assemblage zone and which have been previously described in the literature have, except for Bacutriletes tylotus (HARRIS) POTONIÉ, a vertical distribution which is limited to the Lepidopteris ottonis Zone (Rhaetic) or parts of this. Some of the species, however, extend their occurrence to the basal part of the 
Thaumatopteris schenki Zone (which is considered to be equivalent to the Hettangian) or to a transition zone to this. (See descriptions, figures etc. from Greenland (Harris, 1926, 1935, 1937), Sweden (Brotzen, 1950; Lundblad, 1950, 1959), Poland (MARCinKIEWICZ, 1962, 1969), Northern Germany (ReiNHARdT, 1963; WiCher, 1942, 1951, 1957; Will, 1969), Southern Germany (Jung, 1960), Holland (Ten Dam, 1947) and England (Lewarne \& Pallot, 1957)). B. tylotus (HARRIS) PotoniÉ has in Southern Germany (Franken) been found only in the Thaumatopteris schenki Zone, while it in North Europe and in Greenland is limited to the Lepidopteris ottonis Zone and the basal part of the Thaumatopteris schenki Zone.

It may therefore be supposed that the interval of the $T$. pinguis Assemblage Zone belongs to the Rhaetic. This supposition is supported by a find of Lepidopteris ottonis (Goepr.) Schimp. in the sample $\mathrm{M}_{87}$ (see pl. X, figs. 4, 5).

The $T$. pinguis Assemblage Zone may, on the basis of the vertical distribution of the megaspore species and the lithological composition of the profile (as given in Sorgenfrei \& BUCH (1964) and LARSEN (1966)), be correlated with Rhätkeuper in Northwest Germany, which comprises the Contorta Schichten overlain by the Triletes Schichten (see WILL, 1969). It should here be noted that WILL's terms Rhätkeuper plus the Präplanorbis Schichten correspond to the Middle to Upper Rhaetic in WicheR's subdivision of 1951 (WILL, fig. 40).

In the SP-curve for Rødby No. 1 (LARSEN, 1966, pl. XV) the interval 1858'$2103^{\prime}$ corresponds to WILL's Triletes-Anomalie, while the interval 2170'-2260' correlates with the Haupt-Anomalie ("Mittelrhät Hauptsandstein") (see WILL, 1969, pl. 4). Hence it may be assumed that the T. pinguis Assemblage Zone in Rødby No. 1 comprises an interval which corresponds to the Contorta Schichten and the Triletes Schichten in Northwest Germany.

This assumption is supported by a comparison between the Northwest-German and the Danish megaspore flora, which shows that the pattern of distribution of species in Rødby No. 1 is similar to that of Northwest Germany, where the Triletes Schichten contain an assemblage rich in species (20 species in all), while the Contorta Schichten are characterized by an assemblage poor in species ( 6 species in all). The dominating species in WILL's pinguis assemblage, namely $T$. pinguis (Harris) Potonié, $V$. utilis MarcinkIEWICZ $(=T$. wicheri Will), $T$. pedinacron (Harris) Potonié, B. tylotus (Harris) Potonié, and $V$. litchi (Harris) PotoniÉ, are all found, with the exception of $V$. litchi, in the $T$. pinguis Assemblage Zone, in which they all are frequent.

While it is thus demonstrated that the $T$. pinguis Assemblage Zone correlates with the Rhätkeuper in Northwest Germany, a subdivision of the zone in two intervals corresponding to the Contorta Schichten and the Triletes Schichten is problematical, since the samples from the boundary interval in question, $\mathrm{M}_{76}-\mathrm{M}_{85}$, are non-fossiliferous. The author suggest that the boundary may be placed at the base of the upper sandy series, corresponding to a depth of $2115^{\prime}$ (= about $641 \mathrm{~m}$ below ground level). 
The correlation with the Rhaetic in Northwest Germany has in part confirmed the earlier stratigraphical interpretation of the boring Rødby No. 1 (SoRGENFREI \& BUCH, 1964; LARSEN, 1966), in which the interval 1837.5'-2350' was referred to the Rhaetic (the interval 2320'-2350', situated above the calcareous Middle Keuper beds, is lithologically similar to the beds of the lower part of the T. pinguis Assemblage Zone). However, SORGENFreI \& BUCH's upper boundary of the Rhaetic must be considered to be doubtful, since it seems to be established only on the occurrence of "megaspores with circular fold" in the samples below 1837.5'. The analysis of the megaspore flora and the ostracod fauna (p. 16) makes probable the placing of the upper boundary of the Rhaetic at 1858' (between the samples $\mathrm{M}_{52}$ and $\mathrm{M}_{53}$ ), so that the boundary corresponds to the upper boundary of the $T$. pinguis Assemblage Zone.

The N. hopliticus Assemblage Zone: The characteristical species in this zone, Nathorstisporites hopliticus JUNG and Verrutriletes franconicus JUNG, have in the type area of Franken in Southern Germany a vertical distribution corresponding to the Thaumatopteris schenki Zone. At Sassendorf are found beds which contain plant remains (but which at that location contain no megaspores) of the younger flora that corresponds to the Thaumatopteris flora. These beds are overlain by marine beds with Schlotheimia angulata (Lias Alpha 2). By reason of this the younger flora, and with it the $N$. hopliticus assemblage, in Franken is assumed not to be younger than the Hettangian (see JUNG, 1960; Harris, 1937; LundBlad, 1959). While $V$. franconicus hitherto has been described from only one locality outside of the type area, namely in Bornholm, together with $N$. hopliticus, (GRY, 1969), N. hopliticus has been found to have a large geographical distribution (Greenland, North and Central Europe, South Australia), and it is generally considered to be a useful index fossil for the Thaumatopteris schenki Zone (see discussion in LundBLAD, 1956). The other two species in the $N$. hopliticus assemblage, namely Horstisporites areolatus (Harris) Potonié and Horstisporites harrisi (Murray) Potonié (= H. semireticulatus JUNG $=$ Erlansonisporites reticulatus (ZERNDT) MARCINKIEWICZ), have a relatively large vertical distribution (Lower to Middle Jurassic) and are therefore of limited stratigraphical importance (see JUNG, 1960; MARCINKIEwiCZ, 1960, 1962; HARris, 1961; and others). Consequently the dominating occurrence of $N$. hopliticus together with the occurrence of $V$. franconicus in the uppermost samples indicate the dating of the $N$. hopliticus Assemblage Zone to Hettangian.

WILL (1969) sets the boundary between the Präplanorbis Schichten and the Psiloten Schichten equal to the upper boundary of the occurrence of the $T$. pinguis assemblage, as this assemblage continues in a somewhat weakened form up into the basal part of the Lias where it is suddenly replaced by a $N$. hopliticus assemblage without any overlap (see WiLL 1969, p. 133 and p. 23-33). Since $N$. hopliticus occurs only in small number in the "interval of overlap" $\left(\mathrm{M}_{50}-\mathrm{M}_{52}\right)$, it may be assumed that this interval correlates with the Präplanorbis 
Schichten in Northwest Germany. This is to a certain degree confirmed in SORGENFREI \& BUCH (1964), in which the interval 1835'-1837.5' (which lies between the samples $\mathbf{M}_{49}$ and $\mathbf{M}_{50}$ ) is referred to "Lias (pre-planorbis zone)".

If the results of the interpretation of the megaspore analysis are combined, it is possible to establish the following chronostratigraphical division of the Rhaeto-Liassic section in the boring Rødby No. 1, in that an evaluation of SORGENFREI \& BUCH's interpretation of the interval $1549^{\prime}-1835^{\prime}$ is not included (this interval is discussed in the section dealing with the ostracods):

$$
\begin{array}{ll}
469 \mathrm{~m}-556 \mathrm{~m}\left(1549^{\prime}-1835^{\prime}\right) & \text { Lias Alpha 1-2 } \\
556 \mathrm{~m}-563 \mathrm{~m}\left(1835^{\prime}-1858^{\prime}\right) & \text { Lias, Pre-planorbis Zone } \\
563 \mathrm{~m}-641 \mathrm{~m}\left(1858^{\prime}-2115^{\prime}\right) & \text { Upper Rhaetic } \\
641 \mathrm{~m}-713 \mathrm{~m}\left(2115^{\prime}-2350^{\prime}\right) & \text { Middle Rhaetic }
\end{array}
$$

The depths are given in meters below the ground and feet below the Kelly Bushing (cp. pl. XVII and SORgenfrei \& BuCH, 1964).

\section{Composition of the ostracod fauna.}

The interval studied may, on the basis of the ostracod fauna, be divided in two sections, namely the interval with Upper Triassic ostracods (lower) and the interval with Lower Jurassic ostracods (upper). The boundary between these two sections falls between the samples $\mathrm{M}_{52}$ and $\mathrm{M}_{53}$ and is placed at the depth of $1858^{\prime}$.

In the samples $\mathbf{M}_{53}, \mathbf{M}_{105}$, and $\mathbf{M}_{107}$ have been found a few unbroken valves and a large number of fragments of a thin-valved form which shows affinity with the genera Darwinula Brady \& RoBertson (1885) and Darwinuloides Mandelstam (1956). This form will be described by Bruun Christensen \& MICHELSEN in a work in preparation on ostracod faunas from the Keuper and Rhaetic of the Danish deposits.

Lower Jurassic ostracods have been found in the samples $\mathbf{M}_{8}, \mathbf{M}_{10}-\mathbf{M}_{15}$, $\mathrm{M}_{18}, \mathrm{M}_{20}, \mathrm{M}_{21}, \mathrm{M}_{27}, \mathrm{M}_{34}, \mathrm{M}_{35}, \mathrm{M}_{41}-\mathrm{M}_{43}, \mathrm{M}_{45}, \mathrm{M}_{47}, \mathrm{M}_{49}, \mathrm{M}_{51}$ og $\mathrm{M}_{52}$. In most of these samples the ostracod fauna is characterized by the occurrence of Ogmoconchella aspinata (DREXLER). The interval covered by the above-mentioned samples, 1588'-1858', is named after this species the $O$. aspinata Assemblage Zone. The accessory species of this zone are the following:

Procytheridea medioreticulata n. sp.

Lophocythere elegans DREXLER

Macrocypris No. 4023

Polycope No. 4065

Paradoxostoma? cf. P. ? fusiformis DREXLER

Stenestroemia? roedbyensis n. sp.

Lophocythere No. 4061

Lophocythere sp. (4076)

Procytheridea sp. (4081) 
O. aspinata is the absolutely dominating form in the lower part of the profile, except for the samples $\mathrm{M}_{51}$ and $\mathrm{M}_{52}$, which are completely characterized by fairly fragmentary larval valves referred to the species $P$. medioreticulata. The upper part of the interval, samples $\mathrm{M}_{8}, \mathrm{M}_{10}-\mathrm{M}_{13}$, and $\mathrm{M}_{15}$, is likewise dominated by this species, while $O$. aspinata is decreasing in number. In sample $\mathrm{M}_{8}$, L. elegans is common. The samples $\mathrm{M}_{20}$ and $\mathrm{M}_{21}$ differ from all the others in being rich in both species and specimens. In these two samples $O$. aspinata dominates, making up about $70 \%$ of the total number. They are also characterized by the maximum occurrence of $S$. ? roedbyensis and by the occurrence of Macrocypris No. 4023.

\section{Stratigraphical correlation:}

In the mainly sandy section below $1858^{\prime}$ ostracods are only sparsely represented. The fauna in the three samples $\mathbf{M}_{53}, \mathbf{M}_{105}$, and $\mathbf{M}_{107}$ must be considered to be of Upper Triassic age. In the North European basins of sedimentation, species of the genus Darwinula are characteristic of certain parts of the Rhaetic and Keuper (see BruUn Christensen, 1962, Urlichs, 1966, and Wicher, 1957).

Most of the species in the $O$. aspinata Assemblage Zone are known from deposits referred to Lias Alpha. In Germany $O$. aspinata is frequent in the $S$. angulata Zone (Lias Alpha 2) and is also known in both the P. planorbis Zone (Lias Alpha 1) and the A. bucklandia Zone (Lias Alpha 3). In the Danish boring Gassum No. 1 O. aspinata occurs throughout that interval which on the basis of the ammonite fauna is referred to Lias Alpha. Among the accessory species in the $O$. aspinata Assemblage Zone, L. elegans, $P$. medioreticulata (= Ostracod No. 108 KLINGLer) and $P$. ? fusiformis have stratigraphic significance. In Germany they are known from the $S$. angulata Zone and the lower part of the A. bucklandia Zone. P. medioreticulata is in the boring Gassum No. 1 known from the entire Lias Alpha. In the same boring L. elegans is found only in the upper part of those beds which with some uncertainty have been referred to the Lower Sinemurian (see NøRvang, 1957, p. 313). In the Øresund borings the latter species is, together with $P$. ? cf. $P$. ? fusiformis and Polycope No. 4065 known from that part of the Döshult beds which have been referred to Lias Alpha (BruUn Christensen, 1968). Macrocypris No. 4023 is in the boring Gassum No. 1 common in those beds which have been referred to Lower Sinemurian and uppermost Hettangian.

The pronounced difference between the faunas in the samples $\mathrm{M}_{52}$ and $\mathrm{M}_{53}$ marks the boundary between the interval with Upper Triassic ostracods and the $O$. aspinata Assemblage Zone. On the basis of this faunal shift the RhaeticLias boundary is in the boring Rødby No. 1 placed at the depth of 1858' (see pl. XVII). The quantitative distribution of $O$. aspinata, showing a maximum in the middle of the interval, correlates with German deposits with faunas from Lias Alpha 1, 2 and 3. The occurrence of P. medioreticulata in the lowermost part of the section (samples $\mathrm{M}_{51}$ and $\mathrm{M}_{52}$ ) contrasts with its normal 
distribution in other localities. These two samples must, nevertheless, in the author's opinion belong to the lowermost part of Lias Alpha in this boring. The decreasing tendency of $O$. aspinata in the upper part of the $O$. aspinata Assemblage Zone taken together with the presence of such species as $P$. medioreticulata and $L$. elegans makes possible a correlation with Lias Alpha 2 and 3 lower. It seems thus possible to correlate indirectly with the Hettangian and the lower part of the Lower Sinemurian.

On the basis of the macrofossils the interval $1835^{\prime}-1837.5^{\prime}$ has previously been referred to the Pre-planorbis Zone (see Sorgenfrei \& Buch, 1964). This interval is situated immediately above the samples $\mathrm{M}_{51}$ and $\mathrm{M}_{52}$, which contain the deviating ostracod fauna. It is therefore likely that the Pre-planorbis Zone should include the entire interval 1835'-1858'. The occurrence of Psiloceras planorbis (SOWERBY) in the interval 1825'-1827' (see SORGENFREI \& BUCH, 1964) supports the above tentative conclusion, which is based on the ostracod faunas. On the basis of the ostracod fauna, the $P$. planorbis Zone is supposed to include the samples $\mathrm{M}_{44}-\mathrm{M}_{49}$. According to SorgenfreI \& BuCH (1964) the interval $1798^{\prime}-1807^{\prime}$ is referred to the Lias Gamma on the basis of the macrofossils. Of these fossils only one species, namely Beaniceras cf. centaurus (D'OrBIGNY) is known from the Pliensbachian. The specimen of this species found is determined with uncertainty, according to Sorgenfrei \& BUCH. Another species, Paleoneilo galatea (D'ORBIGNY), is in Northwest Germany and England known from Lias Alpha-Epsilon, and the other species of macrofossils are in Scania and Bornholm known from deposits referred to Lias Gamma. O. aspinata is dominating in the samples I, $\mathrm{M}_{43}$ and II, which fall within this interval (1798'$\left.1807^{\prime}\right)$. From this it is apparent that the deposits referred to Lias Gamma in Sorgenfrei \& BUCH (1964) contain ostracods from Lias Alpha.

On the basis of this the Lias section in the boring Rødby No. 1 may be divided chronostratigraphically in the following way:

Sample $\mathrm{M}_{8}-\mathrm{M}_{11}(480-485 \mathrm{~m})$ : Upper Hettangian or Lower Sinemurian.

Sample $\mathrm{M}_{12}-\mathrm{M}_{43}(485-547 \mathrm{~m})$ : Upper Hettangian.

Sample $\mathrm{M}_{44}-\mathrm{M}_{52}(547-563 \mathrm{~m})$ : Lower Hettangian.

The depths are given in meters below the ground surface (cp. pl. XVII and Sorgenfrei \& BuCH, 1964).

\section{DESCRIPTION OF THE MEGASPORES}

Notes: The systematic classification of the megaspores follows the artificial morphographic taxonomic system which is based on the form-genera established by РотоNIÉ (1956, 1958, 1960 and 1966).

The descriptive terminology corresponds in the main with the one given in PоTONiÉ \& KREMP (1955); however, instead of the terms "Dehiszensmarke", 


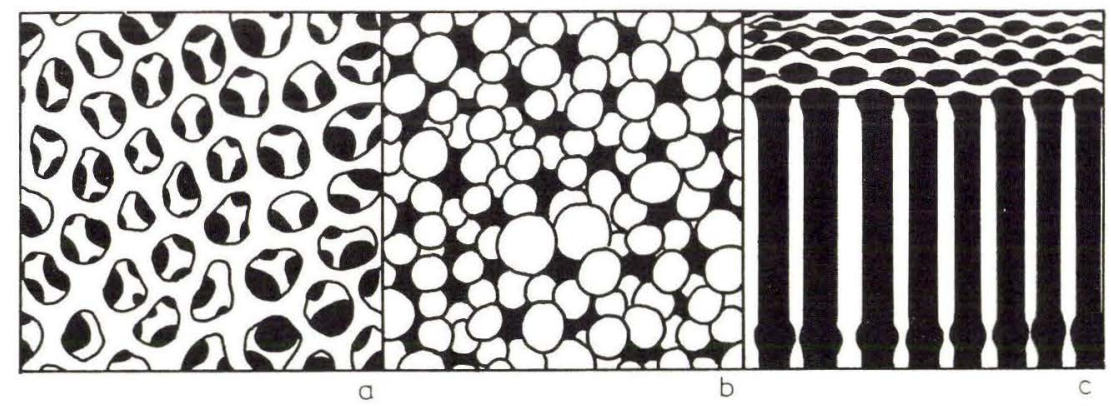

Text-fig. 1. The structure types of the outer part of the ektexine.

"Y-marke" etc. the term laesura is used (ERdTMAn, 1969). In the description of the individual layers of the spore wall the terms ektexine, endexine and mesospore is used in the sense given in PEтTiтT (1966).

In the descriptions of the ektexine structure the following terms are used (cf. text-fig. 1): a) Spongy, microreticulate structure (cp. pl. VIII, figs. 2, 4, 6). This is a structure in which the ektexine is made up of a three-dimensional network in which the shape of the connections may vary from cylindrical to hourglass-shaped. Thus the cavities become rounded in section. b) Spongy, microgranular structure (cp. pl. III, figs. 2, 4, 6). In this structure the ektexine is made up of more or less sphaerical bodies connected so as to form a spongy tissue. The cavities are here polygonal with concave sides, in section. c) Radial, tubular structure (cp. pl. II, figs. 3, 5). In this case the ektexine is perforated by radial, closely spaced tubes. This structure is possibly equal to the so-called "prismatische Struktur" of Potonié \& Kremp (1955, p.17).

The study of the exine structure is based mainly on examination in the scanning electronic microscope on account of the large degree of resolution possible in this instrument, but is also based on observations of macerated spores and, in the case of one of the species, on thin sections of the exine. The structure of the ektexine may, at least as far as the outer layers is concerned, relatively easily be studied in the scanning electronic microscope and in slides with macerated spores. The endexine, if it is present, may, on the contrary, only be described in thin sections. A study of the structure of the endexine is therefore not included in this work. The presence of a mesospore is, however, easier to observe in fragments and in macerated spores, and consequently the exine descriptions in this work also include possibly present mesospores.

Dimensions of the megaspores are given as the maximal diameter of the spore body, so that the height of possibly present sculpture elements is not included in this measure. Since the megaspores in many cases were somewhat deformed, the measures given must be used with caution.

The number of specimens in a sample is given in brackets following the sample number. An (x) means that the species occurs only as fragment(s). 
Anteturma Sporites H. PotoniÉ 1893

Turma Triletes REINSCH 1881

Subturma Azonotriletes LUBER 1935

Infraturma Laevigati (BenNie \& Kidston 1886) R. PotoniÉ 1956

Genus Calamospora Schopf, Wilson \& Bentall 1944

Calamospora rhaetica (JuNG 1960) PoTONIÉ 1966

Pl. I, figs. 1, 2.

1960. Leptotriletes rhaeticus JuNG, pl. 26, figs. 2-4.

Holotypus: JuNG 1960, pl. 36, fig. 3; slide $\mathbf{M}_{96}$.

Locus typicus: Germany, Oberfranken, Öslau bei Coburg, Alte Grube des Annawerkes bei Theissenstein; Rhät-Lias.

Material: Rødby No. 1 samples $M_{56}$ (1 ?), $M_{62}(7), M_{63}(2), M_{64}$ (1), $M_{67}$ (7), $M_{68}(1), M_{69}(2), M_{70}(2), M_{71}(17), M_{75}(4), M_{84}(2), M_{86}(1), M_{87}(1), M_{88}(1)$, $\mathrm{M}_{93}\left(1\right.$ ?), and $\mathrm{M}_{95}(2)$.

Description of specimens: Miospores trilete, sphaerical. Laesurae 0.5 radius of spore with poorly developed tecta difficult to observe in dry specimens. Tecta 6-8 $\mu$ high at the pole, $2-4 \mu$ broad, tapering in height toward the equator. Curvaturae and contact areas not distinguishable.

Exine smooth, $3 \mu$ thick as measured in optical section. Structure fine, spongy, micro-granular. Colour changing from straw yellow in dry specimens to amber coloured in wet spores.

All specimens are compressed and the recognition of the tecta is complicated by the presence of pronounced secondary folds.

Dimensions: Size range of dry specimens: $180-250 \mu$.

Comparison: The Danish specimens are considered to be identical with Calamospora rhaetica (JUNG) although their exines are a little stronger than the spore walls of the German specimens.

According to PotoniÉ (1966, p. 24), the genus name Leptotriletes is replaced by Calamospora.

\section{Genus Trileites (ERdtMan 1945, 1947) PotoniÉ 1956}

Trileites cf. pedinacron (HARris 1935) PoToniÉ 1956

Pl. I, figs. 5 and 6 ; pl. II, figs. 1-5.

1935. Triletes pedinacron Harris, pl. 27, fig. 6; text-figs. $52 \mathrm{~S}, \mathrm{~T}$.

1969. Triletes pedinacron WiLL, fig. 7.

Holotypus: Harris 1935, pl. 27, fig.6; slide 4191.

Locus typicus: Greenland, Scoresby Sound, Astarte R., Bed A; Lepidopteris Zone.

Material: Rødby No. 1 samples $\mathrm{M}_{50}(2), \mathrm{M}_{51}(1), \mathrm{M}_{53}(21), \mathrm{M}_{61}(7), \mathrm{M}_{62}(1)$.

Description of specimens: Megaspores trilete with circular to subtriangular equatorial outline. Nearly all specimens flattened in dorso-ventral direction and only few with the original rather flat tetrahedral form preserved. Laesurae straight, 
$0.6-0.9$ radius of spore, with very finely developed tecta, rounded, $2-3 \mu$ high and $2-3 \mu$ broad, not always visible. Sutures often distinguishable and yawning especially in larger specimens. The three terminal points of laesurae are frequently thrown into relief as three raised areas at the proximal sides of compressed spores. Contact areas may be depressed. There are no signs of curvaturae. The exine has a smooth surface and the colour is black with a shiny lustre. The thickness of the spore wall varies between $15 \mu$ and $25 \mu$. In a vertical cross section through the poles of a flattened specimen the thickness is measured to be $16-21 \mu$ on the proximal side and $23 \mu$ on the distal side.

The structure of the exine has been studied in thin sections prepared with a special technique normally used for foraminifera tests (cf. p. 10). The spore wall consists of a homogeneous transparent material perforated by closely spaced fine radiating tubes (pl.II, fig. 3, text-fig. 1c). These seem to have funnelshaped openings to the surface when observed in thin section, but this feature is hardly discernible even with the aid of scanning micrographs (cp. pl. I, fig. 6). Their inner terminations seem to be blind, but an inner layer corresponding to an endexine or to a mesospore is not seen. The tubes are circular in cross section and they seem to be evenly distributed without forming rows or other special patterns. The interval between the straight, not anastomosing tubes is approximately half the diameter of a tube, and in vertical cross section 14-16 tubes are counted for each $10 \mu$. The presence of minor bulges situated at the same position in each tube and symmetrically arranged around the midline of the exine give impression of zonation of the wall when studied at lower magnifications. Such fine details may be observed only with the use of oil immersion at large magnification (x 1000).

A mesospore has been found neither in the thin sections nor in broken specimens.

Dimensions: Max. equatorial diameter of 21 dry specimens $\left(\mathrm{M}_{53}\right): 216-318 \mu$. Mean $273 \mu$. One large specimen in $\mathrm{M}_{61}: 660 \mu$.

Remarks: All spores except the large one are well preserved. The large specimen is corroded and the pores are visible on both the outer and inner surface of the exine (pl. II, fig. 5).

Comparison: The Danish specimens are identical with specimens found in Germany (WiLl, 1969) and in Poland (MarcinkiEwicz, pers. communication). Some of the spores figured by Brotzen (1950, p. 31, fig. 8) and WiCHER (1942, pl. $27 \mathrm{~b}$ ) are also comparable with $T$. pedinacron. The large specimen compares well with the type material from Greenland concerning the outer morphology. The very special exine structure found in the German (WILL, 1969, p. 29: "? Pallisadenstruktur") and Danish specimens has not been noticed by HARRIS, who described the structure as "finely but fairly conspicuously granular" (1935, p. 166). A sure identification with the type specimens is therefore not possible, but there is on the other hand no basis for erection of a new species before the type material has been re-examined. 
The radiating tubular structure of the exine of $T$. cf. pedinacron may possibly be of diagnostic value, as this structure seems to be infrequent among fossil and recent megaspores. The "prismatische Struktur" of Potonié \& Kremp (1955), which is comparable to the tubular structure of $T$. cf. pedinacron, is infrequent in proportion to the "Mörtelstruktur" of those authors (cf. 1955, p. 18). Petritt has not described any similar structures from the fossil spores studied by him, but the exine structure of the recent Marsilea shows some resemblance although it is in many respects different (PetTitT, 1966).

The concentric zonation of the ektexine caused by variations in the structure, as seen in $T$. cf. pedinacron, is apparently not unusual in megaspore walls. This feature has been described by Реттітт (1966, p. 227, concerning the megaspores of Selaginella): "Sections of the megaspore wall examined by phase contrast illumination show that there are structural variation within the outer exine layer. These are evident as concentric zones in the ektexine that appear to result from variation in the amount of interstitial space between the elements composing this layer of the wall".

Trileites pinguis (HARris 1935) POTONIÉ 1956

Pl. I, figs. 3, 4 .

1935. Triletes pinguis HARRIS, pl. 25, fig. 3.

1935. Triletes persimilis HARRIS, pl. 25, fig. 4.

1950. Megaspores of Selaginella hallei-type, LundBLAD, pl. 2, figs. 1-4.

1951. Megaspore 793, 794, 795,796 of WiCHER, pl. 1, figs. 5-8.

1960. Trileites pinguis JUNG, pl. 36, figs. 6-8.

1961. Banksisporites pinguis Dettmann, pl. 1, figs. 1-8.

1962. Trileites pinguis MarcinkIEWICZ, pl. I, figs. 5-7.

1963. Banksisporites pinguis ReINHARDT, pl. II, figs. 9, 11.

1969. Triletes pinguis WILL, fig. 6.

Holotypus: HarRis 1935, pl. 25, fig. 3; slide 4171.

Locus typicus: Greenland, Scoresby Sound, Ryder R., Baiera Bed; Lepidopteris Zone.

Material: Rødby 1 sample: $M_{50}(17), M_{51}(2), M_{52}(4), M_{53}(2), M_{60}(x), M_{61}(10)$, $M_{62}(70), M_{63}(1), M_{65}(2), M_{66}(1), M_{67}(20), M_{68}(x), M_{69}(3), M_{70}(4), M_{71}(26)$, $\mathrm{M}_{75}(21), \mathrm{M}_{86}(1), \mathrm{M}_{87}(2), \mathrm{M}_{95}(1)$, and $\mathrm{M}_{101}(1)$.

Description of specimens: Megaspores trilete with circular to subtriangular equatorial outline. Mature spores are circular, immature spores are smaller and subtriangular. Laesurae $0.7-0.9$ radius of spore, with distinct tecta, about $40 \mu$ high, 15-20 $\mu$ broad, tapering gradually in height and width toward the equator. Curvaturae are not observed, but secondary "Randwulsten" may occur.

Exine smooth, $10-15 \mu$ thick, with a spongy, probably microreticulate struc- 
ture of the ektexine. Mesospore developed as a clear 2-3 $\mu$ thick membrane. Spore colour is normally light brown.

Dimensions: Maximum equatorial diameter of 44 specimens (sample $\mathrm{M}_{62}$ ): 205-420 $\mu$, mean $310 \mu$.

Remarks: The exine seems to be rather plastic, since many specimens show impressions or indentations after sediment grains. Fragments are also uncommon in the samples.

One abnormal spore has four instead of three tecta.

Comparison: The Danish specimens do not deviate from earlier described $T$. pinguis spores, although minor differences may exist. The structure of the ektexine is spongy, apparently microreticulate in the Danish specimens; however, Harris (1935), Jung (1960) and Dettmann (1961) have described the structure of the ektexine as granular. The generic name Banksisporites DETTMANN is not preferable, as pointed out by PoTONIÉ (1966, pp. 21-22).

\section{Infraturma Apiculati (Bennie \& Kidston 1886) Potonié 1956 \\ Genus Maexisporites PotoniÉ 1956}

Maexisporites ef. misellus MARCINKIEWICZ 1962

Pl. V, figs. 1-2.

1962. Maexisporites misellus MARCINKIEWICZ, pl. II, figs. 6-7.

Holotypus: MarcinKiewicz 1962, pl. II, figs. 6-7.

Locus typicus: Poland, bore-hole Mechowo; U. Rhaetic.

Material: Rødby 1 samples $\mathrm{M}_{61}(1), \mathrm{M}_{67}(1), \mathrm{M}_{69}(1)$ and $\mathrm{M}_{75}(1)$.

Description of specimens: Megaspores trilete, with circular equatorial outline. Exact lengths of laesurae unknown, but seem to be 0.5 radius of spore. Tecta $10-15 \mu$ broad. Labra more or less reflected, with winding rounded edges. Contact areas and curvaturae are not distinguishable.

Exine finely granulated with rounded grana partly grown together. Diameter of the grana is 3-4 $\mu$. Structure and thickness of the exine are unknown.

Dimensions: Equatorial diameter of 4 dry specimens: $230-315 \mu$.

Comparison and discussion: The Danish Maexisporites species has a close resemblance to $M$. soldanellus (Dijkstra) Pot. and $M$. obulus (Dijkstra) Pot., from which it can be distinguished by its shorter and indistinct tecta. It is probably identical with $M$. misellus MARCinKIEwicz, but as this species is ill-defined and poorly figured, this question is as yet unsolved.

It may be distinguished from Bacutriletes reticuliferus n. sp. by its granular sculpture, but this distinction is difficult to make in practice, especially when the spores are corroded or uncleaned. More material is needed to define this Maexisporites species. 
Genus Verrutriletes (van der Hammen 1954) Potonié 1956

Verrutriletes franconicus JUNG 1960

PI. IV, figs. 4-6.

1960. Verrutriletes franconicus JunG, pl. 36, figs. 12-20.

1969. Verrutriletes franconicus Gry, fig. 6, No. 4.

Holotypus: Jung 1960, pl. 36, fig. 18; slide $\mathrm{M}_{23}$.

Locus typicus: Germany, Mittelfranken, Gross-Bellhofen bei Lauf, Grosse Grube ? des Tonwerkes Wolfshöhe; Rhät-Lias.

Material: Rødby 1 samples $\mathrm{M}_{4}(57), \mathrm{M}_{5}(3), \mathrm{M}_{6}(4), \mathrm{M}_{7}(2)$.

Description of specimens: Megaspores trilete with convexly triangular to circular equatorial outline. Laesurae straight, $0.7-0.9$ radius of spore, with high $(40 \mu$ at apex), thin (about $6 \mu$ ) tecta. Tecta tapering in height toward the equator, where they terminate angularly, often with a small excrescence with rounded silhouette. The edges of the tecta are undulating because of their thin construction; they are not sharp but rounded and the sutures are often visible. Curvaturae present, blurred or developed as fine lines.

Some specimens are sculptured with $10-15 \mu$ broad, flat, blunt cones or verrucae, concentrated at the contact areas along the tecta and near the apex, whereas some few have the cones spread over the entire surface. Spores with no sculpture are also found.

The ektexine has a spongy, microreticulate structure with small grana $(2 \mu)$ distributed in the surface. Concentrations of grana are found on the verrucae, which are basically built up like the rest of the ektexine. Exine $7-8 \mu$ thick in optical section. Dry specimens have in most cases a light cinnamon-brown colour. Mesospore clear, membraneous, present.

Dimensions: Max. equatorial diameter of dry specimens: 330-550 $\mu$.

Remarks: Only a small number of the recovered spores could be measured, since the thin walls of the spores were easily folded or destroyed during sedimentation or during the preparation.

Comparison: The spores described and figured by JUNG are identical with the Danish specimens. The characteristic angular terminations of the tecta have not been noticed by the German writer, but they may exist (cf. JUNG, 1960, pl. 36, fig. 13).

Verrutriletes utilis (MARCINKIEWICZ 1962) MARCINKIEWICZ 1969

Pl. III, figs. 1-6; pl. IV, figs. 1-3.

1951. Megaspore 792 WICHER, pl. 1, figs. 3-4.

1962. Trileites utilis MARCINKIEWICZ, pl. I, figs. 1-4.

1969. Triletes wicheri WILL, pl. 1, fig. 1a, b.

Holotypus: Marcinkiewicz 1962, pl. I, fig. 1.

Locus typicus: Poland, bore-hole Mechowo; U. Rhaetic. 
Material: Rødby 1 samples $\mathrm{M}_{50}(1), \mathrm{M}_{51}(1), \mathrm{M}_{52}(\mathrm{x}), \mathrm{M}_{53}(1), \mathrm{M}_{61}(\mathrm{x}), \mathrm{M}_{62}(6)$, $\mathrm{M}_{65}(\mathrm{x}), \mathrm{M}_{67}(\mathrm{x})$ and $\mathrm{M}_{70}(1)$.

Description of specimens: More or less globular megaspores, trilete, with circular to subtriangular equatorial outline. Laesurae straight, 0.6-0.9 radius of spore, with conspicuous tecta, $20-30 \mu$ high and broad with rounded triangular profile. Curvaturae also distinct, more rounded than the tecta, but with the same dimensions. Contact areas nearly smooth, or covered with granula or smaller verrucae. Striations or smaller tangentially oriented folds in the contact areas are characteristic features of all the investigated specimens. As the folds are formed in part by changing concentrations of smaller and bigger grana in the surface layer of the exine, they are regarded as a true part of the sculpture although they may have been reinforced to some degree by collapse of the wall during compression of the spore. Distal sculpture may be smooth with scattered grana or the exine may be covered with semiglobular verrucae (less common). The verrucae increase in diameter toward the distal pole; they also cover the curvaturae. The average diameter of the verrucae is about $20 \mu$.

The exine is $12-15 \mu$ thick in the contact areas and $20-25 \mu$ thick in the distal hemisphere. The structure of the ektexine is spongy microgranular. Mesospore present. Colour brown to almost black.

Dimensions: Equatorial diameter of dry specimens: $395-575 \mu$. Fragments show that a great number of the originally imbedded spores must have had larger dimensions than the specimens measured.

Comparison: The Rødby specimens conform in most respects to the descriptions of MARCINKIEWICZ and WILL. No verrucate specimens have been described by MARCINKIEWICZ from the Mechowo boring, but as they later have been found in other borings (personal communication), she has changed the generic name (1969). I agree with the Polish writer in the similarity between V. utilis MARC. and the spores figured by WICHER (1951, pl. 1, figs. 3, 4, megaspore 792) and some of the specimens in fig. 8 by Brotzen (1950, p. 31). The majority of the specimens in WICHER's pl. 27a (1942) also belong to this species.

\section{Genus Bacutriletes (VAN DeR Hammen 1954) Potonié 1956 \\ Bacutriletes reticuliferus n. sp. BERTELSEN \\ Pl. V, fig. 6; pl. VI, figs. 1-4.}

Holotypus: Pl. V, fig. 6; slide Rødby No. $1 \mathrm{M}_{71-\mathrm{x}}, \mathrm{FB}$.

Locus typicus: Bore-hole Rødby No. 1, D.G.U. file No. 240.75.

Stratum typicum: Sand, fine grained, argillaceous, light grey. Bore-hole depth 2059 feet (sample $\mathbf{M}_{71}$ ); Rhaetic.

Material: Rødby 1 samples $\mathrm{M}_{50}(2), \mathrm{M}_{56}(2), \mathrm{M}_{61}(2), \mathrm{M}_{62}(6)$ and $\mathrm{M}_{71}(4)$.

Diagnosis: A Bacutriletes species, more or less globular, with laesura 0.5-0.6 radius of spore. Tecta obscured by the sculpture of rather closely spaced small 
blunt bacula, which cover the whole surface of the spore. Bacula irregularly spaced on sharp ridges forming a basal network with increasing mesh diameter toward the distal pole. No curvaturae.

Ektexine thin, spongy microreticulate. The presence of a mesospore cannot be confirmed with full certainty.

Description of specimens: Small megaspores trilete with circular to subtriangular equatorial outline. Distal side semiglobular, proximal side low pyramidal, often with concave faces. Laesurae $0.5-0.6$ radius of spore, only measurable in transmitted light. Tecta totally covered by exine sculptural elements. Blunt bacula, irregularly spaced on the relatively sharp-edged muri of a reticulum imperfectum, make up the exine sculpture. The flanks of the ridges and the edges connecting the bacula are concave, giving the lumina semicircular profiles. In the apical region the bacula are very closely spaced, especially in concave areas where the bacula may touch. A gradual dissolution and an increasing coarseness of the sculpture toward the distal pole are noticed in most of the specimens. The thickness of the bacula is $3-6 \mu$ and they are less than $10 \mu$ high. The sculpture is about $10-15 \mu$ high measured from the bottom of a lumina to the level of the extreme points of the bacula. As the reticulum is rather irregular no accurate information about the lumina diameters can be given. The distance between two adjacent bacula on the distal side is normally less than $20 \mu$.

The sculpture is destroyed or deformed in most specimens but it is often possible to detect the original configuration in concave areas of the exine. The attacked parts of an exine may look crusty or rough, and sedimentary material remaining in the interstices between the bacula may obscure the sculpture. The exine is about $8 \mu$ thick as measured in the central parts of the lumina. The sculpture and the outer layer of the ektexine have a spongy, microreticulate structure. The structure of the inner parts of the exine is unknown. Colour of spores is light to dark brown.

Dimensions: Observed size range (max. diam.): $190-300 \mu$. Diameter of the holotype: $290 \mu$.

Remarks: This species is difficult to distinguish from Maexisporites cf. misellus MARCINKIEWICZ, and it was necessary to take several micrographs of differently preserved spores with the scanning electronic microscope to reveal the true nature of the exine sculpture.

Comparison and discussion: The reticulate system of connections between the bacula clearly separates this species from the genotype Bacutriletes tylotus (Harris) Potonié as do the entirely sculptured tecta. B. reticuliferus n. sp. cannot be compared with the small Bacutriletes specimens of JUNG (1960, p. 140, cf. Bacutriletes tylotus), as these have the same type of sculpture as Bacutriletes tylotus. Bacutriletes nanus (DiJkstra) Potonié and Bacutriletes minimus (DiJKSTRA) Potonié both fall within the same size range, but they both have conspicuous tecta. Bacutriletes arnoldii (MINER) POTONIÉ and Bacutriletes greenlandicus (MINER) Potonié are much larger, have longer laesurae, and are not reti- 
culate. Bacutriletes gyrus Dettmann is larger, and has distinct tecta. It has also poorly developed bacula at the contact areas.

B. reticuliferus $\mathrm{n}$. sp. seems rather like certain specimens of Verrutriletes litchi (Harris) Potonié described by Will (1969, pp. 32-33), but is distinguished by its reticulate sculpture and its baculate non-verrucate processes.

\section{Bacutriletes tylotus (Harris 1935) POTONIÉ 1956 \\ Pl. V, figs. 3-5.}

1935. Triletes tylotus Harris, pl. 26, figs. 1, 12; text-figs. 53 F-I.

1957. Triletes tylotus Lewarne \& Pallot, figs. 3a-3d.

1960. Bacutriletes tylotus JUNG, pl. 37, figs. 21-27.

1962. Bacutriletes tylotus Marcinkiewicz, pl. III, figs. 1-3.

1963. Bacutriletes tylotus ReINHARDT, pl. II, fig. 12.

1969. Triletes tylotus WiLL, pp. 31-32.

Holotypus: HARRIS 1935, pl. 26, fig. 12; slide 4051.

Locus typicus: Greenland, Scoresby Sound, Astarte R., Lepidopteris Bed; Lepidopteris Zone.

Material: Rødby 1 samples $\mathrm{M}_{50}(3), \mathrm{M}_{51}(\mathrm{x}), \mathrm{M}_{52}(\mathrm{x}), \mathrm{M}_{53}(1), \mathrm{M}_{61}(6), \mathrm{M}_{62}(13)$, $\mathrm{M}_{63}(\mathrm{x}), \mathrm{M}_{64}(\mathrm{x}), \mathrm{M}_{65}(\mathrm{x}), \mathrm{M}_{67}(4), \mathrm{M}_{71}(2), \mathrm{M}_{75}(1), \mathrm{M}_{86}(1)$.

Description of specimens: Megaspores trilete, globular with circular equatorial outline. Laesurae $0.6-0.7$ radius of spore with irregular crest-shaped tecta, indistinct, about $20 \mu$ broad and $10-25 \mu$ high.

Exine evenly or unevenly covered with obliquely truncated or blunt, straight or curved bacula $10-40 \mu$ long and $5-10 \mu$ broad. A common feature is the groups of bacula joined in sculptural units formed like truncated cones with elongated bases. The distance between the groups may be rather large, up to $40 \mu$, whereas the distance between the simple bacula normally is smaller, from $5-10 \mu$. The sculpture is most pronouncedly developed at the distal face and decreases gradually in development toward the apex in the majority of the specimens. A smaller number of the spores has a more uniform sculpture.

The exine is smooth with a few unevenly scattered granules between the appendages. The structure of the ektexine is spongy microreticulate, and the minute cavities in the bacula are arranged in such a way as to give an appearance of fine transversal striations when the bacula are studied in transmitted light. Exine about $15 \mu$ thick. Mesospore present.

Remarks: This type of spore makes only slight resistance to compression, and consequently in some samples it is represented only by a large number of fragments.

Dimensions: Equatorial diameter of dry specimens : 300-490 $\mu$, typically 430 $450 \mu$.

Comparison: Only minor differences in the shape of the tecta separate the 
Danish spores from the specimens described by HARRIS. The general trend toward smaller appendages around the proximal pole is not mentioned in HARRIS' work, but this feature has been observed by JUNG and WILL. The development of the tecta in the Rødby spores compares well with WILL's specimens, which are also equipped with rather high tecta.

\section{Infraturma Murornati PotoniÉ \& KRemP 1954 \\ Genus Horstisporites Potonié 1956 \\ Horstisporites areolatus (HARRIS 1935) POTONIÉ 1956 \\ PI. VI, figs. 5, 6.}

1935. Triletes areolatus Harris, pl. 26, figs. 3, 10.

1960. Horstisporites areolatus JuNG, pl. 37, figs. 28-30.

1961. Triletes areolatus Harris, text-fig. $19 \mathrm{E}$.

1962. Horstisporites areolatus MARCINKIEWICZ, pl. IV, figs. 1-2.

1967. Horstisporites areolatus DREYER, pl. IX, fig. 12.

1969. Horstisporites areolatus GRY, fig. 6, No. 5.

Holotypus: HarRIS 1935, pl. 26, fig. 3; slide 4120.

Locus typicus: Eastgreenland, Scoresby Sound, Lejr. R., Czekanowskia Bed; Thaumatopteris Zone.

Material: Rødby 1 samples: $\mathrm{M}_{4}(7), \mathrm{M}_{7}(\mathrm{x}), \mathrm{M}_{25}(1), \mathrm{M}_{32}(\mathrm{x})$.

Description of specimens: Megaspores trilete with circular equatorial outline. Laesure normally $0.7-0.8$ radius of spore, with rather low to crestformed tecta about $30 \mu$ broad near the pole, but tapering toward the equator. Tecta are smooth and straight with visible sutures. Exine sculptured with a reticulum perfectum of slightly rounded polygonal meshes. Lumina are in average $25-35 \mu$, showing some variation from spore to spore. In the individual spore, there is only a small variation in the sculpture from the distal to the proximal hemisphaere. Curvaturae may sometimes be indistinctly seen in the sculpture. Muri about $5-10 \mu$ thick, broadest at their bases, and rounded. They are about $20 \mu$ high.

Exine, exclusive of the muri is $20 \mu$ thick and comprises an outer finely microreticulate, spongy layer $16 \mu$ thick and an inner homogeneous, transparent layer about $4 \mu$ thick (? mesospore). The colour is greyish brown.

Dimensions: Equatorial diameter of 7 dry specimens: $510 \mu-905 \mu$.

Comparison: The Danish specimens show no morphological divergences in comparison with formerly described specimens.

\section{Horstisporites harrisi (MURRAY 1939) POTONIÉ 1956 Pl. VII, figs. 3, 4.}

1939. Triletes harrisi Murray, text-figs. 1-2.

1960. Horstisporites semireticulatus JunG, pl. 38, figs. 31-38. 
1960. Erlansonisporites reticulatus (ZERNDT) MARCINKIEWICZ, pl. V, fig. 3.

1961. Triletes harrisi Harris, text-fig. 18 E, F.

1962. Erlansonisporites reticulatus (ZERNDT) MARCINKIEWICZ pl. V, figs. 8-10.

1967. Horstisporites semireticulatus DREYER, pl. IX, figs. $10 \mathrm{a}, \mathrm{b}$.

1967. Horstisporites afi. harrisi Stoermer \& Wienholz, pl. X, fig. 89 a, b.

1969. Horstisporites harrisi GRY, fig. 6, No. 8.

Holotypus: Murray, 1939, text-figs. 1-2.

Locus typicus: England, Little Bytham, Lincs.; Bed 18, Up. Deltaic

Series, M. Jurassic.

Material: Rødby 1 samples $\mathrm{M}_{4}(2), \mathrm{M}_{50}\left(1\right.$ ?), $\mathrm{M}_{52}(\mathrm{x}$ ?).

Description of specimens: Megaspores trilete with circular to oval equatorial outline. Laesurae $0.6-0.7$ radius of spore, with straight, strong tecta, $50 \mu$ high at apex, tapering in height toward the equator. The thickness is less than $20 \mu$, and the edges are rather sharp. Contact areas distinct, sculptured with loosely connected ridges and globular, knotty thickenings. Distal side covered by an irregular extra reticulum with low relief and with mesh diameter increasing toward the distal pole. Mesh diameter on distal side is $25-30 \mu$ in average. Muri are $5 \mu$ high and broad, and has an appearance as if polished. Curvaturae are marked only by the change in sculpture.

The exine is greyish brown and is about $20 \mu$ thick. The structure is unknown.

Dimensions: Equatorial diameter of two dry specimens: $480 \mu$ and $500 \mu$.

Comparison: The criteria of JUNG for a distinction between Horstisporites harrisi (MurRay) POT. and Horstisporites semireticulatus JUNG have lost their value with the appearance of the emended diagnosis for $H$. harrisi published by HARRIS in 1961, as already remarked by GRY (1969). The Rødby specimens compare well with the spores described by HARRIS and JUNG, and comparison with the Middle Jurassic specimens of $H$. harrisi found in Bornholm and figured by GRY (1969, fig. 6, No. 8) have not revealed any differences of importance.

The spores from Poland (Lias Beta-Aalenian) described as Erlansonisporites reticulatus (ZERNDT 1938) by MARCINKIEWICZ $(1960,1962)$ show close affinity to H. harrisi (compare e.g. with MARCINKIEwICZ, 1962, pl. V, fig. 8-10) and are therefore included in the list of synonyms for this species.

Triletes reticulatus ZERNDT 1938 from the Polish Mesozoic Blanowicer Kohle is uncertainly defined and may consequently not be considered as type for $H$. harrisi (Murray 1939) POT. even though it was described a year before $H$. harrisi. Fig. 5, pl. 155, 1938 (ZERNDT) shows two megaspores, the upper one of which may possibly be identified with $H$. harrisi, while the lower one probably belongs to the species $H$. areolatus (HARRIS) POT. The description, except for the small thickness of the exine, $8 \mu$, fits $H$. areolatus, in that it is stated that the contact areas are not distinguished by any special sculpture: "Die Bogenlinien sind kaum angedeutet, was, in Verbindung mit der Leistenskulptur der Gesamtoberfläche, bedingt, dass sich die Kontaktflächen nicht abheben" (1938, p. 1729). 
Horstisporites rexargenteus (HARRIS 1935) POTONIÉ 1956

Pl. VII, figs. 1, 2.

1926. Megaspore Type 3 Harris, text-fig. 1, C, D.

1935. Triletes rexargenteus HarRis, pl. 26, fig. 13; text-fig. G-J.

?1951. Megaspore 798 WiCHER, pl. 1, fig. 10.

Holotypus: Harris 1926, text-fig. 1, C.

Locus typicus: Greenland, Scoresby Sound, Wielandiella Shale; (Lepidopteris Zone).

Material: Only one large fragment in Rødby 1 sample $\mathbf{M}_{68}$.

Description of specimen: Megaspore dark brown with exine about $50 \mu$ thick. Estimated original diameter more than $450 \mu$. Tecta rounded, straight, $15 \mu$ high, 15-20 $\mu$ broad, ? longer than radius (one branch could be measured to $240 \mu$ ). Exine with a reticulum perfectum consisting of deep lumina, round to oval in shape, 10-20 $\mu$ across, separated by rounded muri with a thickness of about half the diameter of the surrounding lumina as measured at their central parts. The depth of the reticulum is approximately $3 / 4$ the thickness of the exine. No other sculpture is observed, except that curvaturae are marked by changes in the thickness of the muri.

Comparison: The fragment compares well with the specimens described by HARRIS. It also shows close affinity to Megaspore 798 of WICHER, but this spore has more irregular pits. It is not identical with Horstisporites cavernatus MARCINKIEWICZ, from which it differs in the thickness of the exine.

\section{Horstisporites sp. (Type No. 5)}

Pl. VII, figs. 5-6.

Material: Rødby 1 samples $\mathrm{M}_{95}(\mathrm{x}), \mathrm{M}_{102}(1), \mathrm{M}_{103}(1)$.

Description of specimens: Megaspores trilete with circular to subtriangular equatorial outline. Laesurae nearly as long as the spore radius with very conspicuous strong and board-formed tecta tapering gradually in height toward the equator. Tecta $100-150 \mu$ high and about $20 \mu$ thick, with straight or wavy, rounded edges. Contact areas distinct, nearly smooth, but having the same granular surface as the tecta. Distal side covered with a coarsely meshed, imperfect to perfect extra reticulum with polygonal to longish rectangular meshes. The muri are thin $(8-15 \mu)$ with jagged, sharp edges but may also be rounded and polished. The muri oriented parallel to the longitudes are often stronger and more perfect than those with latitudinal orientation. The ridges are normally about $20 \mu$ high, but peaks are usually formed where they unite. The curvaturae are formed by more or less winding ridges. The lumina are not caved in and their diameter is approximately $50-100 \mu$.

The exine is almost black, is relatively thin $(10-15 \mu)$ and brittle and has a spongy microgranular structure. Mesospore seems to be missing. 
Dimensions: The equatorial diameter of the two dry specimens is about $450 \mu$.

Comparison and discussion: This species is very similar to some variants of Erlansonisporites sparassis (MURRAY) PoTONIÉ and Horstisporites harrisi (MURRAY) POTONIÉ as regards the distal sculpture, but it is clearly distinguished from both of these species by its sculptureless contact areas. H. areolatus (Harris) Potonié, H. casses (Harris), H. cavernatus Marcinkiewicz, H. corticetenuis (Vangerow) Potonié, H. kendalli (Harris), H. microlumenus Dettmann and $H$. reticuliferus (DIJKsTRA) POTONIÉ may be left out of consideration since they all have uniformly reticulate sculptures which show no change from the proximal to the distal face of the spores.

\section{Turma Barbates MÄDLER 1954 \\ Genus Nathorstisporites JUNG 1958 \\ Nathorstisporites hopliticus JUNG 1958 \\ Pl. VIII, figs. 1-6.}

1908. Lycostrobus scotti megaspores NATHORST, pl. I, figs. 1-13.

1926. Lycostrobus scotti Harris, pl. X, fig. 1.

1935. Lycostrobus scotti Harris, pl. 26, figs. 6, 7, 11, 14, text-fig. $51 \mathrm{~K}-\mathrm{Q}$. 1946. Lycostrobus scotti HARRIS, pl. 1, fig. 5.

1951. Lycostrobus scotti WICHER, pl. 1, figs. 1, 2.

1956. Lycostrobus scotti LundBLAD, pl. 1, figs. 1-8.

1958. Nathorstisporites hopliticus Jung, pl. 3, figs. 1, 6, 9-11.

1960. Nathorstisporites hopliticus JunG, pl. 39, figs. 44-50.

1960. Lycostrobus scotti MARCinKiEWICZ a.o., pl. 1, figs. 1-4.

1961. Nathorstisporites hopliticus Dettmann, pl. 3, figs. 1-5, text-figs. 1c, 2.

1962. Nathorstisporites hopliticus MARCINKIEwICZ, pl. IV, figs. 3-6.

1967. Nathorstisporites hopliticus DreYER, pl. IX, figs. 11a, b.

Holotypus: Jung 1958, p. 121; pl. 3, fig. 10.

Locus typicus: Germany, Mittelfranken, Wolfshöhe; Thaumatopteris Zone.

Material: Rødby 1 samples: $\mathbf{M}_{4}(144), M_{5}(12), M_{6}(27), M_{7}(3), M_{15}(1), M_{16}(1)$, $M_{18}(15), M_{19}(6), M_{20}(7), M_{22}(10), M_{23}(19), M_{25}(94), M_{27}(1), M_{30}(14), M_{31}(5)$, $M_{32}(12), M_{33}(6), M_{35}(x), M_{40}(1), M_{44}(4), M_{45}(3), M_{48}(x), M_{49}(x), M_{51}(6)$ and $\mathrm{M}_{52}(1)$.

Description of specimens: Megaspores trilete with circular to subtriangular equatorial outline, depending on the degree of maturity. Laesurae about 0.8 radius of spore. Tecta straight, crestformed, wearing highly dentated, incised, clear membranes, which are up to $150 \mu$ high at the pole and which taper slightly in height toward the equator. Along the tecta long, band-shaped and often bifurcated capilli make up the sculpture. They decrease gradually in height and complexity toward the curvaturae. They are about $10 \mu$ broad. Exine covered with verrucae (pl. VIII, figs. 1, 2) or coni or capilli (pl.VIII, figs. 3, 4, 6). The 
basal parts of these three types of sculptural elements are always extensions of the spongy microreticulate ektexine, whereas their outer parts consist of the same clear material which forms the tecta membranes and the surrounding capilli. Small clear grana or coni are often distributed in the surface of the exine and may be concentrated at the tops of the larger cones or verrucae as shown by Jung (1958, p. 122, fig. 2). The basal diameter of the cones or verrucae is $25-40 \mu$ in average and their height is about $20-30 \mu$. The capilli are normally $40-60 \mu$ long. The cones are evenly distributed with a distance of $20-50 \mu$ being common. The forms, proportions and distribution of the sculptural elements do not vary in the individual spore, but among the specimens large variations occur.

Exine $10-15 \mu$ thick as measured between the coni. Colour brown. Mesospore present.

Dimensions: Equatorial diameter of 186 dry specimens: 305-610 $\mu$, mean value $450 \mu$ (specimens from $\mathrm{M}_{4}$ and $\mathrm{M}_{25}$ ).

Remarks: This megaspore is very common in the Rødby No. 1 material. It is generally well preserved, but a few weak specimens (specimens wearing capilli on the distal side) may be partly destroyed.

Comparison: During the preliminary study of the material it was attempted to divide the fairly large material of Nathorstisporites spores into two groups corresponding to JunG's two species $N$. hopliticus and $N$. peltasticus (JunG, 1958). This attempt was, however, given up, as a large unclassifiable residual group was formed. Another attempt at classification, namely on the basis of the distal sculpture being verrucate or capillate, was also given up, since the appearance of a number of intermediate stages made this solution impossible. Instead all the spores have been classified as N. hopliticus JUnG. The Danish specimens correspond in size to the dimensions given for the Middle European ones (see Jung, 1958, p. 120).

Turma Zonales (Bennie \& Kidston 1886) Рotonié 1956

Subturma Zonotriletes WALTZ 1935

Infraturma Zonati PotoniÉ \& KREMP 1954

Genus Macrosporites Renault 1899

Macrosporites cf. brasserti (STACH \& ZERndT 1931) Potonié 1956

Pl. X, fig. 3.

1957. Triletes brasserti DiJkstra \& PIÉRART, pl. 4, figs. 61-78; pl. 14, figs. 185 186; pl. 19, figs. 185-186.

Material: Rødby 1 sample $\mathrm{M}_{4}$ contains one fragmentary, corroded specimen.

Description of specimen: Megaspore trilete with circular equatorial outline. The spore is flattened in polar direction, and parts of the distal and proximal face are missing. The diameter is $900 \mu$. Tecta nearly invisible or destroyed, 
reaching the equator. The scanty remains of a presumed corona composed of a few rows of closely spaced radiating capilli have been preserved at the equator. Three groups of capilli are seen, situated near the terminal points of the tecta. The capilli have disc-shaped bases and are 5-12 $\mu$ thick and up to $130 \mu$ long. They have circular cross section, are often bifurcated and perhaps also anastomosing. The width of the three groups of capilli varies from $70 \mu$ to $300 \mu$. Since these groups are not symmetrically placed in relation to the terminations of the tecta and since a fine impression line is seen along those parts of the epuator where the capilli are absent, it is assumed that a complete corona of capillate appendages was originally present.

Exine otherwise sculptureless. It is about $20 \mu$ thick. The structure is unknown.

Remarks: The specimen was cleaned by means of ultra-sound, in which operation part of the distal face was lost.

Comparison: Although rather damaged, this specimen is comparable with Macrosporites brasserti (STACH \& ZERNDT) POT. from the Lower Carboniferous of the Moscow Basin, described and figured by Dijkstra \& Piérart (1957).

Macrosporites beutleri (REINHARDT, 1963) has a more membraneous corona with band-shaped, not round capilli and is also in other ways different. Some specimens of this species from the Keuper of Poland were kindly sent to me by Dr. Marcinkiewicz. M. insignis Renault 1899 has not been figured, but it seems to be closely related to $M$. brasserti (STACH \& ZERNDT) according to Potonié (1966, p. 94). Comparison with this species is impossible, as the description (cited in Potonié 1966) is insufficient.

\section{Genus Minerisporites Potonié 1956}

Minerisporites ales (Harris 1935) Potonié 1956

Pl. XI, figs. 1-6; pl. X, figs. 1-2.

1935. Triletes ales Harris, pl. 25, figs. 2, 8, 9, 11; text-figs. 53A-E.

1960. Minerisporites ales Jung, pl. 38, figs. 39-41; pl. 39, fig. 43.

1962. Minerisporites ales Marcinkiewicz, pl. III, figs. 6, 7.

Holotypus: HarRis 1935, pl. 25, fig. 11.

Locus typicus: Greenland, Scoresby Sound, Ammonite Mtn., Coal Bed;

? Transition Zone between Lepidopteris Zone and Thaumatopteris Zone.

Material: Rødby 1 samples $\mathrm{M}_{61}(6), \mathrm{M}_{62}(13), \mathrm{M}_{67}(1), \mathrm{M}_{68}(1), \mathrm{M}_{70}(1), \mathrm{M}_{75}(4)$, $M_{87}(1), M_{88}(2), M_{93}(8), M_{95}(58), M_{100}(21), M_{101}(27), M_{102}(33)$, and $M_{103}(8)$.

Description of specimens: Megaspores trilete, zonate with globular spore bodies. Spore body with circular to convexly triangular equatorial outline. Diameter 150-260 $\mu$ (dry specimens). Laesurae straight, reaching the equator. Tecta developed as $75-125 \mu$ high, very thin membranes not tapering in height toward the equator. The border of the membrane as a rule not incised but folded and wrinkled. Spore body surrounded by a membraneous zona forming auriculae 
where it is united with the tecta. Zona $15-20 \mu$ broad as measured between two auriculae. Auriculae broadly rounded, angular and as long as the radius of the spore body. Structure of tecta and zona finely reticulate with round lumina (? perforations).

The proximal hemisphere of the spore body is sculptured with round to flat, band-shaped capilli with more or less truncated ends, which are often bifurcated or split. They may be united with one another by means of thin membranes. They reach their highest degree of development near the tecta and the apex, where they are about $0.6-0.8$ times the height of the tecta.

The distal hemisphere has basically the same type of sculpture as the contact areas, but it is more differentiated. Some specimens (pl. IX, figs. 1-2) have round capilli evenly distributed at intervals of $15-20 \mu$, whereas others (pl. IX, fig. 3 ; pl. X, fig. 1) have more band-shaped capilli partly connected by thin membranes forming a reticulum. And finally the sculpture is in some cases developed as a coarsely meshed, irregular reticulum of thin, ragged membranes. The height of the sculpture is normally between $20 \mu$ and $40 \mu$.

The exine has a spongy microreticulate structure and is $3-5 \mu$ thick (as measured in optical section). A mesospore has not been observed. Colour yellow.

Remarks: The spores are generally well preserved, but in two samples $\left(\mathrm{M}_{100}\right)$ and $\left(\mathrm{M}_{93}\right)$ all specimens are destroyed by corrosion. The lower samples $\mathbf{M}_{95^{-}}$ $\mathbf{M}_{103}$, contain only reticulate specimens, whereas the upper samples include spores with capillate, capilli-reticulate and reticulate distal sculpture.

Comparison: Specimens with capillate sculpture are undoubtedly identical with the spores described from Greenland, Poland and Germany. Concerning the transition forms it is believed that the reticulate specimens must be included in Minerisporites ales (HARRIS) POT., although it is suspicious that no purely capillate spores are found in the lower samples. On the other hand, it is not unlikely that future supplementary material will call for a subdivision into two species.

\title{
DESCRIPTION OF THE OSTRACODS
}

\author{
Familia Macrocypridae MülLER 1912 \\ Genus Macrocypris BRADY 1867 \\ Macrocypris No. 4023 \\ Plate XII, figs. $1 \mathrm{a}-\mathrm{b}$; text-fig.2.
}

Material: Sample $\mathrm{M}_{11}$ : 9 carapaces and 2 valves. Sample $\mathrm{M}_{12}$ : 1 carapace, 7 valves and fragments. Sample $\mathrm{M}_{13}$ : (?) 3 valves. Sample $\mathrm{M}_{20}: 13$ carapaces, 7 valves and fragments. Sample $\mathrm{M}_{21}$ : 100 carapaces, 48 valves and fragments. The carapaces and the valves are generally fragmentary.

Description: The carapace is fairly small. In lateral view it is oblong with the 
anterior end more rounded than the posterior end, having its greatest height at a point a third part of the way from the anterior end. In dorsal view it is oblong with evenly curved sides and with a pointed anterior end and a slightly rounded posterior end. The greatest breadth of the shell is at a point posterior to the middle.

The dorsal edge is straight. The margin is slightly curved between the anterior cardinal angle and the well-rounded anterior end. The transition to the nearly straight ventral edge is sharply curved. The posterior margin is sharply curved and continues into the dorsal edge through a slightly convex margin. The larvae have a more pronouncedly angular outline of the shell. In dorsal view the larvae differ from the adults in having a pointed posterior end, so that the greatest breadth of the shell of the larvae is at a point in the anterior third part.

The line of contact is straight in the anterior and the posterior end, while it has a slight bend on the ventral side. Dorsally the hinge line has a characteristical break both at the anterior and the posterior angle. The right valve is larger than the left valve.

The hinge consists of five parts. In the left valve there is posteriorly and anteriorly a transversely crenulated ridge and in the middle a straight and smooth part. Between the ridges and the middle part are two grooves. In the right valve these grooves sit on the external sides of the ridges. Muscle scars have not been seen. The duplicature is more or less fragmentary, but both in the anterior and the posterior end the vestibule seems to be well-developed.

Remarks: This species is probably identical with Paracypris? sp. 854 BRUUN Christensen (1968, pl. 23, fig. 2). A thorough analysis of the latter and corresponding types from other Danish boreholes is in preparation. Macrocypris No. 4023 differs by the outline of its carapace from other known species such as M. terraefullonicae Jones \& SHERborn 1888 and M. horatiana Jones \& SHERborN

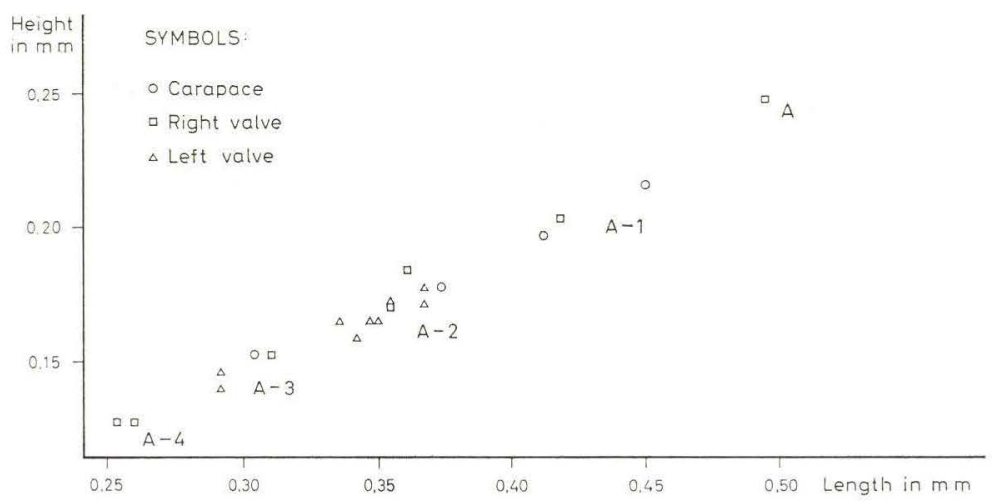

Text-fig. 2. Scattergram showing relations between numbers, lengths, and heights for valves and carapaces of Macrocypris No. 4023 from sample $\mathbf{M}_{21}$. 
1888. Ostracode 3 Us3eck (1952, p. 404, text-fig. 7) seems to have a more rounded dorsal edge and a more pointed anterior end.

Distribution: Paracypris? sp. 854 BRUUn CHRISTENSEN and a similar type from the boring Gassum No. 1 are known only in beds referred to Lias Alpha.

Familia Limnocytheridae KLIE 1938

Genus Stenestroemia BruUn Christensen 1968

Stenestroemia ? roedbyensis n. sp. MICHELSEN

Plate XI, figs. $1 \mathrm{a}-\mathrm{d}, 2 \mathrm{a}-\mathrm{c}, 3 \mathrm{a}-\mathrm{c}$; text-figs. 3-4.

Derivation of the name: From the name of the type locality.

Holotype: A right valve, D. G. U. Catalogue No. 1969-OM-10, pl. XI, figs. $1 \mathrm{a}-\mathrm{d}$, and text-fig. 3 .

Type locality: Borehole Rødby No. 1, D. G. U. file No. 240.75.

Type stratum: Clay, dark grey to greyish black with fine-grained sand. Borehole depth 1681 feet (sample $\mathrm{M}_{21}$ ). Lower Lias.

Material: Sample $\mathrm{M}_{15}$ : 3 fragments. Sample $\mathrm{M}_{20}$ : 11 valves. Sample $\mathrm{M}_{21}$ : 3 carapaces and 78 valves. Sample $\mathrm{M}_{27}: 2$ valves and 1 fragment. Sample $\mathrm{M}_{52}$ : 1 fragment.

Diagnosis: A species with hinge and muscle scar like in the genus Stenestroemia. The posterior end of the carapace is strongly developed and has its largest width posterodorsally. The radial pore canals seem to be narrow and closely spaced.

Description: The outline of the carapace of the female is elongated oval. The dorsal edge is straight with an indistinct anterior cardinal angle. The anterior edge is well-rounded. The ventral edge is straight to slightly rounded and has in the right valve a marked central concavity. The posterior end is slightly curved ventrally and more rounded dorsally, so that the carapace has its greatest length near the dorsal edge. The posterior cardinal angle is distinct, and behind this the right valve has a slight concavity. The two valves are almost equal in size. The right valve overlaps the left valve dorsally, while the opposite is the case ventrally. The outline of the carapace in the male differs from the above description in having posteroventrally a marked hump. Thereby the ventral edge becomes concave. The outline of the carapace of the larvae corresponds to that of the female, but is more smoothly rounded. The posterior end is only slightly unsymmetrical and is slightly narrower than the anterior end.

The greatest height of the carapace is in the adult at a point a third part of the way from the posterior end. Its largest breadth is in the female a little anterior to the median and in the male behind the middle. In both male and female the carapace is in dorsal view elongated oval with the anterior end more pointed than the posterior end. The vertical cross-section is in the female ovoid to subtriangular with the largest breadth ventrally. In the male the cross-section is evenly rounded with the largest breadth at the median. 
The hinge is slightly lophodont and has a groove in the right valve and a corresponding ridge in the left valve. There are four small muscle scars, which are closely spaced on a vertical line. Anterior to these, three small muscle scars may be seen. Dorsally and anterior to the muscle scars is a slightly developed sulcus. It appears more clearly in the male. The zone of concrescence is fairly wide and is perforated by a number of very narrow radial pore canals. These are very difficult to observe, but they seem to be more closely spaced than in the genotype. The duplicature is in all the specimens fragmentary, but it is clear that there must be well-developed vestibules along the anterior, posterior, anteroventral, and posteroventral margins.

The surface of the carapace is smooth. A very few carapaces show a tendency to a very fine striation ventrally, parallel to the edge.

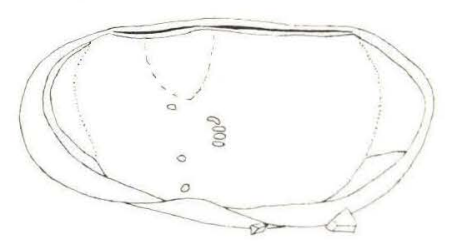

Text-fig. 3. Stenestroemia ? roedbyensis $\mathrm{n}$. sp. Right valve,, , internal view, holotype (plate XI, figs. 1 a-d) $80 \times$. Sample $M_{21}$.

Measurements (in mm): See the text-fig. 4. The figures given for height and length give only a slight indication of the presence of sexual dimorphism. The males are slightly smaller than the females.

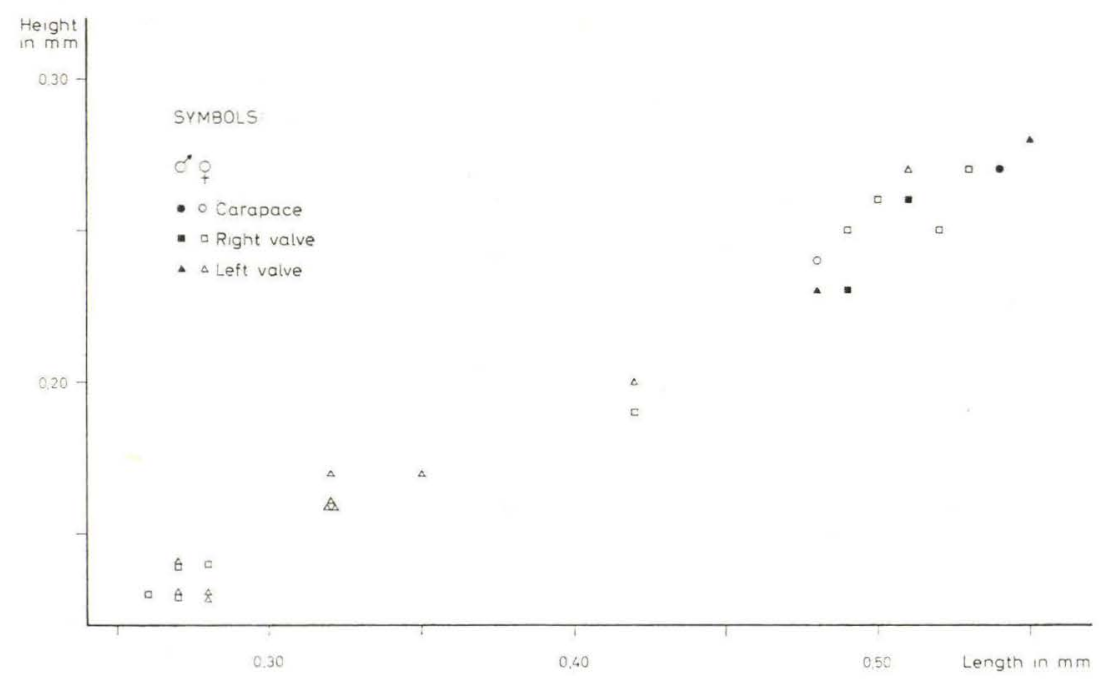

Text-fig. 4. Scattergram showing relations between numbers, lengths, and heights for valves and carapaces of Stenestroemia ? roedbyensis $\mathrm{n}$. $\mathrm{sp}$. from sample $\mathrm{M}_{21}$. 
Remarks: This form is not identical with any known species. In Darwinula sp. UrLichs (1966, p. 16, pl. 2, figs. $8 \mathrm{a}-\mathrm{b}$, 10, text-fig. $5 \mathrm{~b}$ ) the right and the left valves differ more from each other. The inner characteristics are not described. S. ? roedbyensis has affinities to the genus Stenestroemia by the character of the hinge and the muscle scars; however, the shape of the carapace and lack of knowledge concerning the radial pore canals make the reference to this genus uncertain.

$S$. ? roedbyensis may probably be considered to be a species from a mixohaline environment.

\section{Familia Paradoxostomatidae Brady \& Norman 1889 \\ Subfamilia Paradoxostomatinae Brady \& NORMAN 1889 \\ Genus Paradoxostoma FISCHER 1855}

Paradoxostoma ? cf. P. ? fusiformis DREXLER 1958

Plate XII, figs. 2 a-b.

1968. Paradoxostoma? ef. P.? fusiformis Drexler, Bruun Christensen, pl. 23, fig. 8 .

Material: Sample $\mathrm{M}_{12}: 6$ valves. Sample $\mathrm{M}_{13}: 1$ valve. Sample $\mathrm{M}_{15}: 1$ carapace and 7 valves. Sample $\mathbf{M}_{20}: 1$ carapace and 3 valves. Sample $\mathbf{M}_{21}: 2$ carapaces and 12 valves.

Remarks: The valves studied are poorly preserved. They are very thin and often seem to be deformed, so that they cannot be measured. The largest specimen, sample $\mathrm{M}_{21}$, has a length of $0.32 \mathrm{~mm}$ and a height of $0.15 \mathrm{~mm}$. These measures are to be used with some caution, but when compared with the dimensions given by DreXLer (1958, p. 526) they seem to confirm that the material from the boring Rødby No. 1 only contains larvae.

The external surface is completely smooth. Muscle scars and hinge are not observed. Thus this species is difficult to place, but it seems to be identical with Paradoxostoma? cf. P.? fusiformis in BruUn Christensen (1968). It differs from $P$. ? fusiformis DREXLER in having a wider posterior end and a broadly rounded anterior end.

Distribution: P. ? fusiformis is known from Lias Alpha 2 and lower Alpha 3 in Western Germany (DREXLER, 1958). In the Øresund boreholes it occurs in that part of the Döshult beds which are referred to Lias Alpha (BRUUN Christensen, 1968).

Familia Progonocytheridae Sylvester-Bradley 1948

Subfamilia Progonocytherinae SyLVESTER-BRADLEY 1948

Genus Lophocythere SyLveSTER-BRADLEY 1948

Lophocythere elegans DREXLER 1958

Plate XII, figs 3 a-b. 
1952. Ostracode 7 UsBeck, p. 405, pl. 18, figs. 64 a-b.

1958. Lophocythere elegans DreXler, p. 523, pl. 24, figs. 5 a-e, pl. 27, figs. 10-11.

Material: Sample $\mathrm{M}_{8}: 5$ valves.

Measurements (in $\mathrm{mm}$ ):

\begin{tabular}{|c|c|c|c|}
\hline Sample & Valve & Length & Height \\
\hline $\mathrm{M}_{8} \ldots \ldots \ldots \ldots \ldots \ldots \ldots \ldots$ & L. (Left) & 0.34 & 0.15 \\
\hline$-\ldots \ldots \ldots \ldots \ldots \ldots \ldots \ldots \ldots$ & R. (Right) & 0.32 & 0.18 \\
\hline 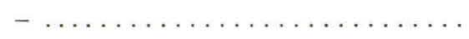 & R. & 0.33 & 0.16 \\
\hline$-\ldots \ldots \ldots \ldots \ldots \ldots \ldots \ldots \ldots \ldots \ldots \ldots$ & $\mathrm{R}$. & 0.30 & 0.15 \\
\hline
\end{tabular}

Remarks: The specimens studied are identical with L.elegans DrEXLER 1958. However, the hinge is difficult to interpret and muscle scars have not been observed in these valves.

L. elegans Drexler in BruUn Christensen (1968, pl. 23, fig. 12) is, in the present author's opinion, not identical with the holotype. The form shown by BRUUn CHRISTENSEN has fairly fine transversal ribs, while L elegans has coarse, diagonal ribs. A study of the material from the Øresund boreholes shows, however, that L. elegans also is present in the Döshult beds.

Distribution: L. elegans is in Germany known from Lias Alpha 2 and lower Alpha 3 (DreXler, 1958). Usbeck (1952) mentions it from the upper part of the $S$. angulata Zone (upper Alpha 2).

\section{Lophocythere sp. (4076)}

Plate XII, figs. 4 a-b.

Material: Sample $\mathrm{M}_{8}: 5$ valves.

Measurements (in $\mathrm{mm}$ ):

\begin{tabular}{|c|c|c|c|}
\hline Sample & Valve & Lenght & Height \\
\hline $\mathrm{M}_{8} \ldots \ldots \ldots \ldots \ldots \ldots \ldots \ldots$ & R. (Right) & 0.29 & 0.16 \\
\hline 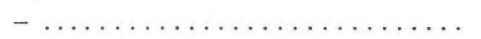 & R. & 0.29 & 0.14 \\
\hline$-\ldots \ldots \ldots \ldots \ldots \ldots \ldots \ldots \ldots \ldots$ & R. & 0.30 & 0.16 \\
\hline 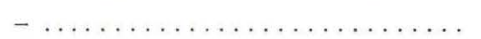 & L. (Left) & 0.25 & 0.13 \\
\hline
\end{tabular}

Remarks: This form has some resemblance to L. elegans DreXLER. However, it is a little smaller, and the sculpture is rounded with a concentric tendency. On the ventral side are thin ribs which run parallel to the ventral edge through the entire length of the valve. Anteriorly they bend upwards. Centrally on the lateral side there is a smoothly rounded rib which both anteriorly and posteriorly is surrounded by concentric ribs. A smaller area centrally located at the dorsal edge is without any sculpture. Between the ribs are fine transversal ribs. The hinge is difficult to interpret. Muscle scars have not been observed.

Distribution: This form is known only from the boring Rødby No. 1. 


\section{Lophocythere? No. 4061}

Plate XII, figs. 5 a-b.

Material: Sample $\mathrm{M}_{20}: 2$ valves. Sample $\mathrm{M}_{21}: 5$ valves.

Description: The carapace is small. In lateral view it is oviform with an evenly arched surface and with its greatest height anteriorly. In dorsal view the outline is evenly curved with the greatest breadth centrally.

The dorsal edge is almost straight. The anterior cardinal angle is obtuse. The rounded anterior edge has at the transition to the ventral edge a slight bend. The ventral edge is almost straight and has a small concavity centrally. The posterior edge forms with its semicircular appearance a smooth transition between the dorsal and the ventral edge. The shape of the carapace is characterized by the narrow posterior end and the obliquely rounded anterior end. The right valve is a little smaller than the left valve.

The external surface is characterized by a pitted reticulation. The pits are arranged in oblong, concentric figures conformal with the outline of the valves.

The hinge seems to be entomodont and has sockets in the left valve. The area with the muscle scars is small and round and is placed a little anterior to the middle of the valve. It is impossible to distinguish the individual muscle scars.

Remarks: This form does not resemble any known form. It has with some uncertainty been referred to the genus Lophocythere SYLVESTER-BRADLEY 1948. The hinge is difficult to observe. The muscle scar area is different, and the reticulation is of another type than what is normal for this genus. Because of the shape of the valve it is for the present referred to Lophocythere.

Distribution: Lophocythere? No. 4061 is known only from the two samples mentioned.

\section{Subfamilia Protocytherinae LyUBimova 1955 \\ Genus Procytheridea Peterson 1954}

Procytheridea medioreticulata n. sp. MICHELSEN

Plate XIII, figs. 1 a-d, 2 a-c; text-fig. 5.

? 1952. Ostracode 4 Usbeck, p. 404, pl. 18, figs. 61 a-d.

1962. Ostracod No. 108 Klingler, pp. 79-80, pl. 12, fig. 3.

Derivation of the name: Referring to the restriction of the sculpture to the middle part of the valve.

Holotype: A right valve, D.G.U. Catalogue No. 1969-OM-6, pl. XIII, figs. $1 \mathrm{a}-\mathrm{d}$.

Type locality: Borehole Rødby No. 1, D. G. U. file No. 240.75.

Type stratum: Clay, dark grey to greyish black with fine-grained sand. Borehole depth 1595 feet (sample $\mathrm{M}_{10}$ ). Lower Lias.

Material: Sample $\mathrm{M}_{8}$ : 1 carapace and 106 valves, mostly as fragments. Sam- 
ple $\mathbf{M}_{10}: 19$ valves. Sample $\mathbf{M}_{11}: 4$ valves. Sample $\mathbf{M}_{12}: 49$ valves. Sample $\mathrm{M}_{13}$ : 9 valves. Sample $\mathrm{M}_{15}$ : 40 valves, mostly as fragments. Sample $\mathrm{M}_{18}$ : ? fragments. Sample $M_{20}$ : 1 fragment. Sample $M_{51}: 3$ carapaces and 1 valve, larvae. Sample $\mathrm{M}_{52}$ : 48 carapaces and 98 valves, all fragmentary larvae.

Diagnosis: A species of the genus Procytheridea. Surface reticulate in the middle part, with a tendency to a triangular arrangement of the ridges in which one side of the triangle is parallel to and near the ventral margin. The posterodorsal margin of the right valve is distinctly concave.

Description: The anterior end of the left valve is well-rounded. The anterodorsal margin rises in a flat arch to the anterior cardinal angle, at which point the largest height can be measured. Between the anterior and the posterior hinge tooth area the dorsal edge is slightly concave. The posterior cardinal angle is pronounced. From it the margin goes in a flat arch down to the narrow and rounded posterior end. The ventral edge is almost straight and has a slight concavity in the foremost part. The right valve is smaller than the left valve. Its outline corresponds fairly closely to the above description, except that the dorsal edge between the two tooth regions is slightly convex. Immediately in front of the anterior cardinal angle is a slight concavity. Behind the posterior cardinal angle the margin is pronouncedly concave, so that the posterior end is narrow and lobe-shaped. The outline of the carapace in the larvae corresponds fairly closely to the above description; however, the posterodorsal concavity in the right valve is less pronounced.

In dorsal view the carapace is elongated oval with plane-parallel to slightly biconcave sides. The anterior and the posterior edges project clearly from the oval outline.

The hinge is antimerodont. The anterior tooth region has in the right valve 6-7 teeth and the posterior has 7-8 teeth. Between the two regions is a finely cross-corrugated groove. The left valve has corresponding socket areas with a ridge between them. The hinge flanges are in both valves fairly broad. The zone of concrescence is broad in the anterior end. It contains eight straight radial pore canals. The inner edge and the line of concrescence coincide. The normal pore canals are fairly broad. In the middle of the inner side of the valves is a vertical ridge which extends through almost the entire height of the valve. The muscle scar area is elongated and is located in front of and parallel to this ridge. It consists of four small muscle scars which sit closely together in a straight line. In a very few cases another muscle scar has been observed in front of these.

In this species the surface sculpture is developed in varying degree. Normally the sculpture is distinct in the central part of the valve. In some cases it is strongly developed and distinct in almost the entire valve, while in other cases it seems to be lacking. Along the ventral border each valve has three to four ribs which extend through almost the entire length of the valve. The lateral sides are divided by the ribs into fields, giving an impression of a triangular 
pattern in which one side is parallel to the ventral edge. The central part of this pattern is found opposite to the muscle scars. The zone along the anterior, posterior and dorsal margins lacks sculpture. A distinct concavity extends from the vicinity of the anterior tooth region obliquely forward.

Measurements: Measurements have been made in two of the samples, $\mathrm{M}_{8}$ and $\mathrm{M}_{10}$ (see text-fig. 5). In sample $\mathrm{M}_{10}$ the material is very scant, but it shows a distinct division into three instars. In sample $\mathrm{M}_{8}$ the number of measurable valves is larger. They are divided into the same three instars and a smaller larval stadium. Between the three larval stadia in this distribution there are two other groups. The valves in these two groups do not differ in any respect from those of the other groups, except for size. Consequently it is not possible to demonstrate any species dimorphism in the material. This difference in size is presumably caused by the environment, reflecting a mixture of individuals from two different environments. The size of recent ostracods seems in a few cases to depend upon variations in temperature and salinity (Neale 1964) and the amount of food (PURI 1966). Calculated on the basis of the interpretation of the subdivision shown in text-fig. 5, the growth factor varies about 1.26.

Remarks: Procytheridea medioreticulata is identical with Ostracod No. 108 KLINGLeR and is possibly identical with Ostracode 4 UsBeck. It differs from P. triebeli Klingler \& Neuweiler 1959 in having a more open and regular sculpture. P. multicostata KLINGLER \& Neuweiler 1959 has a larger heightto-length ratio and has a fan-shaped sculpture.

In most of the samples both adults and larvae occur, in a manner similar to that shown in text-fig. 5. Sample $M_{12}$ lacks adults, and samples $M_{51}$ and $\mathrm{M}_{52}$ have only the two smallest larval stadia (A-2 and $\mathrm{A}-3$ ).

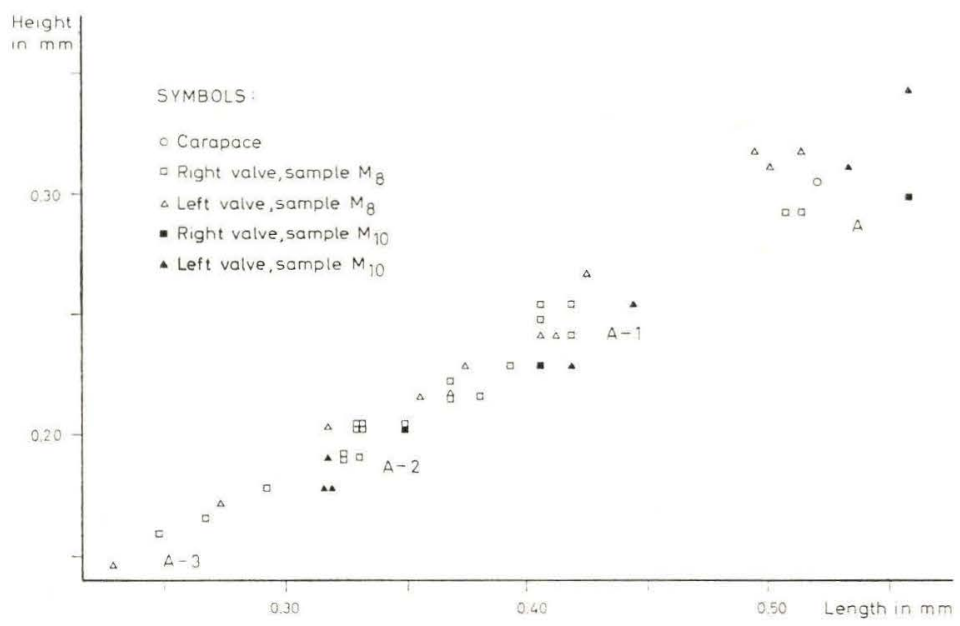

Text-fig. 5. Scattergram showing relations between numbers, lengths and heights for valves and carapaces of Procytheridea medioreticulata n. sp. from samples $\mathrm{M}_{8}$ and $\mathrm{M}_{10}$. 
Distribution: KuINGLeR (1962) notes about Ostracod No. 108: "Lias alpha 2-3 unten". UsBeck (1952) writes about Ostracode 4: "Im oberen Teil des Alpha 1 und im gesamten Alpha 2 häufig".

\section{Procytheridea sp. (4081) \\ Plate XIII, figs. 3 a-c.}

Material: Sample $\mathrm{M}_{18}: 1$ carapace and 3 valves.

Measurements (in $\mathrm{mm}$ ):

\begin{tabular}{|c|c|c|c|}
\hline Sample & Valve & Length & Height \\
\hline$\ldots \ldots \ldots \ldots \ldots$ & Carapace & 0.63 & 0.33 \\
\hline 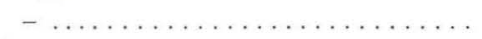 & Right & 0.52 & 0.26 \\
\hline - & Right & 0.48 & 0.26 \\
\hline
\end{tabular}

Remarks: These specimens differ from $P$. medioreticulata in having a more pronounced sculpture and a smaller height-to-lenght ratio. Their statistical distribution seems to exclude the possibility that they represent males belonging to $P$. medioreticulata.

In the same sample are a few fragments of $P$. medioreticulata.

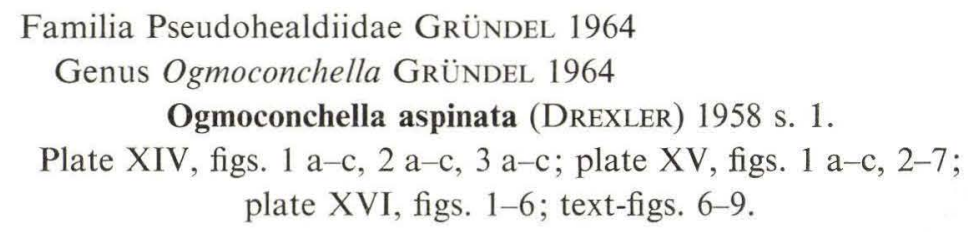

1938. Ostracode (521) WiCHER, pl. 27, fig. 1.

1952. Ogmoconcha sp. (1) UsBeck, p. 404, pl. 18, fig. 59 a-b.

1958. Healdia aspinata DreXler, p. 505, pl. 21, figs. 5 a-e, pl. 25, figs. 1-4. 1961. Healdia aspinata Drexler, Pietrzenuk, pl. 15, fig. A-4.

1962. Healdia aspinata DreXler, Klingler, p. 79, pl. 12, figs. 1-2.

1964. Ogmoconchella aspinata (DREXLER), GRÜNDEL, p. 470, figs. 5-7.

Material: Sample $\mathrm{M}_{8}: 1$ valve. Sample $\mathrm{M}_{10}: 3$ fragmentary carapaces. Sample $\mathrm{M}_{11}: 2$ carapaces and 7 valves. Sample $\mathrm{M}_{12}: 3$ carapaces and 99 valves. Sample $\mathrm{M}_{13}: 3$ valves. Sample $\mathrm{M}_{15}: 12$ carapaces and 53 valves. Sample $\mathrm{M}_{20}$ : 35 carapaces and 89 valves. Sample $\mathrm{M}_{21}$ : 319 carapaces and 756 valves. Sample $\mathrm{M}_{27}$ : 12 carapaces and 103 valves. Sample $\mathbf{M}_{41}$ : 10 carapaces and 3 valves. Sample $\mathrm{M}_{42}$ : 133 carapaces and 185 valves. Sample I: 11 carapaces and 37 valves. Sample $\mathrm{M}_{43}$ : 33 carapaces and 92 valves. Sample II: 16 carapaces and 62 valves. Sample $\mathrm{M}_{45}: 1$ valve. Sample $\mathrm{M}_{49}: 1$ carapace and 16 valves. - Some of the here listed specimens are fragmentary. In addition to these, the samples contain many uncounted fragments.

Description: The carapace is large. In lateral view it is rounded subtriangular, 
in dorsal view oviform to drop-shaped. The vertical cross-section is oval to oviform.

The largest height of the left valve is located a little behind the middle, at a point where the dorsal edge makes a distinct bend. From this point forward the dorsal edge makes an even arch down toward the well-rounded anterior end, which passes evenly into the almost straight ventral edge. The transitions between the ventral edge and the posterior edge and between the posterior edge and the dorsal edge are marked by sharp curves. The posterior edge is only slightly convex and is oblique, so that the greatest length is at the upper part of the posterior edge. The dorsal edge rises steeply from the posterior end up to the above-mentioned bend. The outline of the right valve is more softly rounded and is more elongated oval than that of the left valve. The ventral edge is slightly concave and the posterior end is evenly rounded. The left valve is larger than the right valve and overlaps it. The overlap is especially large along the central part of the dorsal edge and along the ventral edge. The anterior end of the right valve has a long, narrow lamella which extends a little bit out over the left valve. This lamella, which is very thin, often is lacking in the adult, perhaps because it has been broken off.

In dorsal view the oviform carapace has a broadly rounded posterior end and a more pointed anterior end. Especially the left valve has this appearance, since the right valve has a more rounded anterior end. The largest breadth of the carapace is at a point posterior to the middle. In the larvae the difference between the two valves is smaller. In the smallest larvae $(\mathrm{A}-7)$ the difference in outline and size seems to be almost completely none. The larvae, especially the smaller ones, have a subtriangular outline. Also the vertical cross-section is subtriangular.

The inner edge is in both valves well-rounded in both the anterior and the posterior end. Ventrally it is slightly concave and dorsally it is distinctly convex. In the left valve the surrounding contact groove is ventrally fairly broad, while anteriorly and posteriorly it is narrow. Dorsally the hinge line is broad, but it is not so pronouncedly depressed as the contact groove is. The contact groove and the hinge form an unbroken peripheral groove, which is sculptured with fine cross-ribs. In the right valve the free margin and the hinge line likewise have fine cross-ribs along the entire periphery of the valve.

The area of adductor muscle scars is circular, in a few cases with a tendency toward an oval shape. It is composed of seven large muscle scars which are arranged pairwise along a vertical axis in the area. They are surrounded by 11-12 smaller scars which together with the seven large muscle scars form an almost circular area. There are two small additional muscle scars, one dorsally and the other one anterior to this area. In the larvae the area of adductor muscle scars is more or less reduced. In the last larval stadium (A-1) the outer ring of small muscle scars may be difficult to observe.

The outer surface of the valves is smooth or has fine pits. The right valve 
in the adult has on the anterior edge a long and narrow lamella. In the larvae such a lamella is present in both valves and is equipped with a small forwardpointed spine. The larvae have, likewise, in the right valve a posteroventral, backward-pointed spine. Only the smallest larval stadium (A-7) lacks this spine.

Remarks and measurements: In the material examined this species occurs in two different ways. In the upper part of the profile, sample $\mathbf{M}_{8}-\mathbf{M}_{42}$, all stadia (the seven larval stadia and the adult one) are equally represented (see textfig. 6), while the adult and last larval stadium preponderate in the lower part of the profile (see text-fig. 9). The adult stadium is identical with Healdia aspinata DreXLer. The shape of the muscle scar area and the number of muscle scars in the form examined differs from the description of DREXLER (1958). However, it agrees with the description of GRÜNDEL (1964).

As mentioned above, only the right valves of the larvae (except A-7) have a posteroventral spine. In this they somewhat resemble Healdia nasuta DrEXLER 1958 and $H$. telata DreXLer 1958. These two, however, have a spine on both valves. The material examined may not easily be subvided into two species on

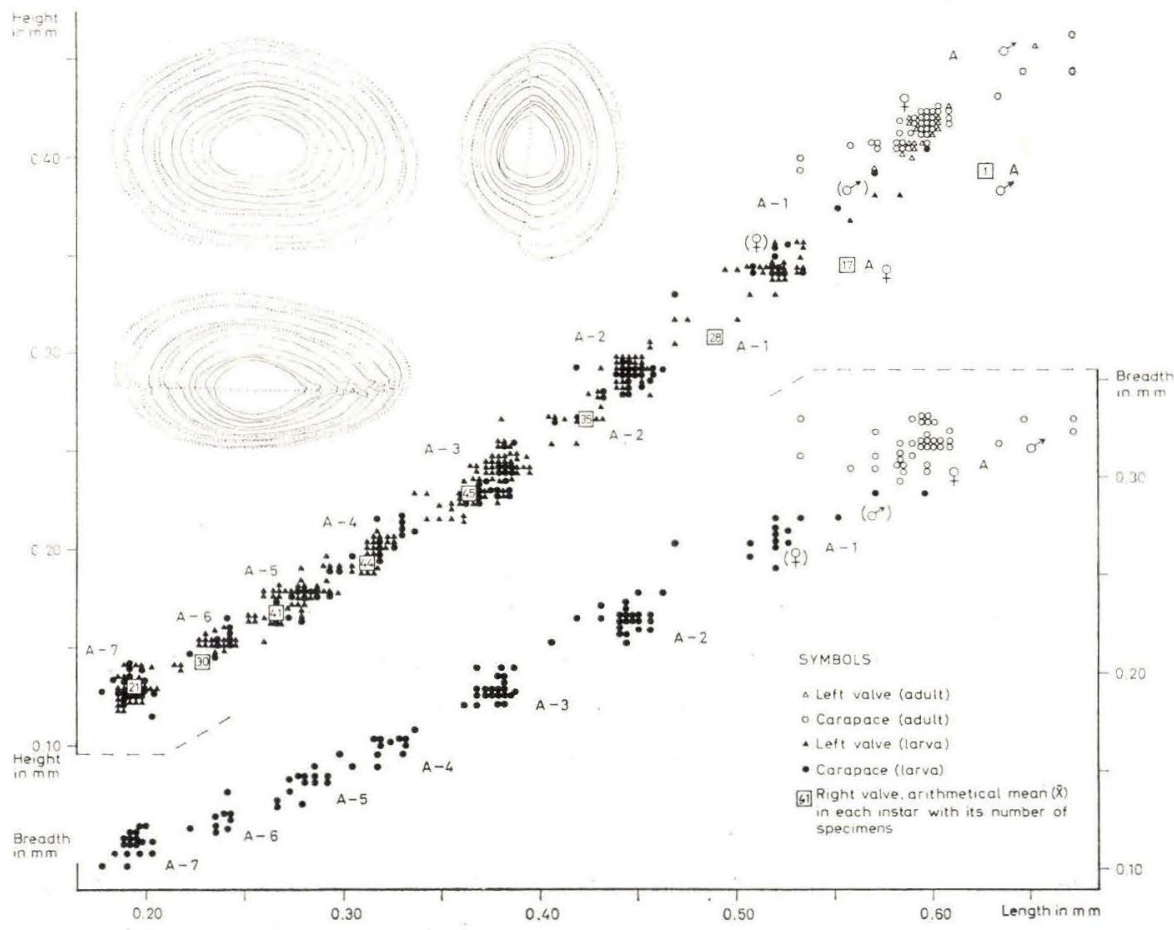

Text-fig. 6. Scattergrams showing relations between numbers, lengths, heights and numbers, lengths, breadths for Ogmoconchella aspinata (DREXLER) 1968 from sample $\mathrm{M}_{21}$. Right valves, represented by their arithmetical means, are also figured at text-figs. 7 and 8 . One specimen from each instar is drawn with a full line, and the presumed males with a dotted line. 
the basis of presence or absence of the posteroventral spine. Since valves with and without spine in no other characteristics show any marked difference from each other such a subdivision will be very difficult for the left valves.

In order to illustrate the problem statistically, all complete specimens in the samples $\mathrm{M}_{21}$ and II have been measured. The result is given in tables I-III and in text-figs. 6-8. Text-fig. 6 shows the relation between length and height of all carapaces and left valves in sample $\mathrm{M}_{21}$. The right valves are represented by the arithmetical mean $(\overline{\mathrm{X}})$ for each instar. The relations between the means are rectilinear, while the means of the left valves show a weak positive allometry. The relation between length and breadth of the carapace, which is also given in the same diagram, shows a similar picture. The text-figs. 7 and 8 show right valves without and with spine respectively. None of these three diagrams can, in the opinion of the author, form a base for a subdivision in two species.

Those specimens which in text-fig. 6 are marked as adults (A) are identified as such on the basis of the shape of the left valve to that of the right valve and the shape of the contact groove and the free margin. These specimens seem to be distributed in two groups, females and males. The last larval stadium (A-1) shows a similar distribution, by reason of which the presence of sexual dimorphism is assumed for this stadium also. The instars A-2 and A-3 seem to show the same tendency. Characteristic for the instars named is a distribution

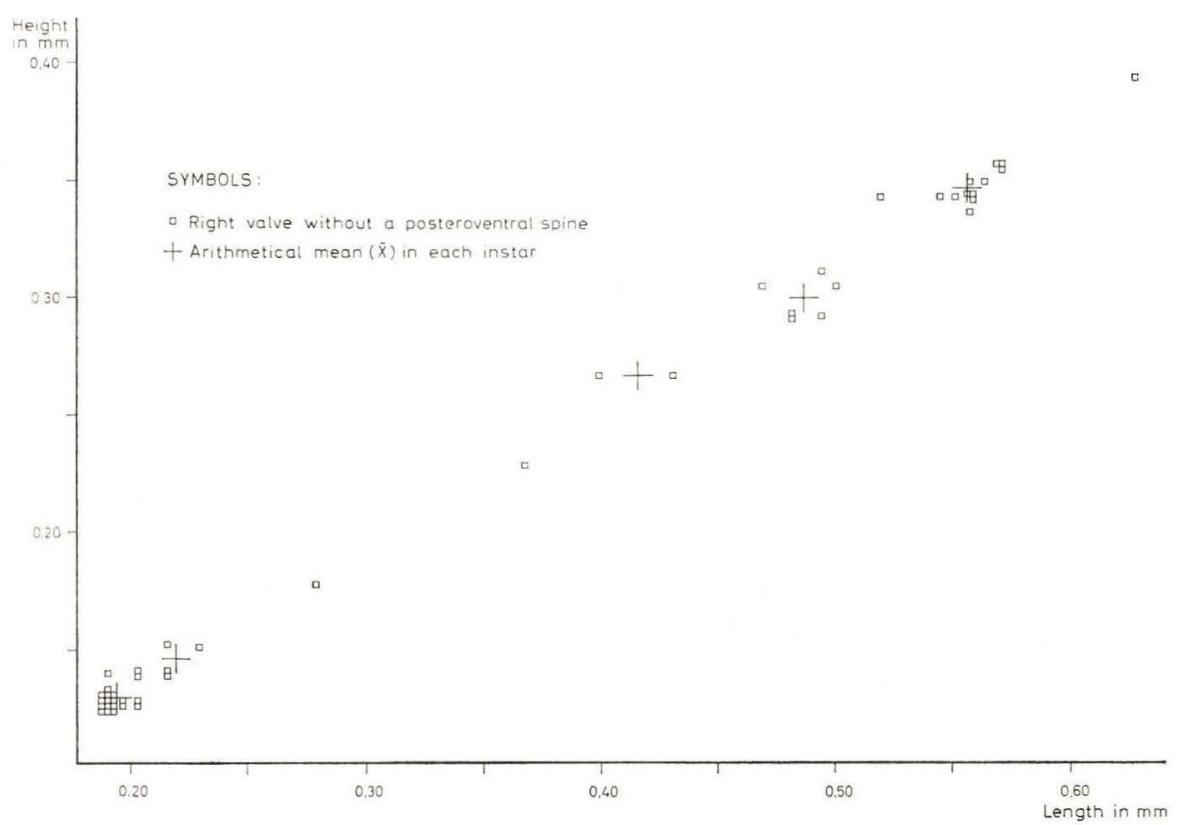

Text-fig. 7. Scattergram showing relations between numbers, lengths, and heights for right valves without a posteroventral spine of Ogmoconchella aspinata (DREXLER) 1958 from sample $\mathbf{M}_{21}$. These specimens are also figured at text-fig. 6 . 


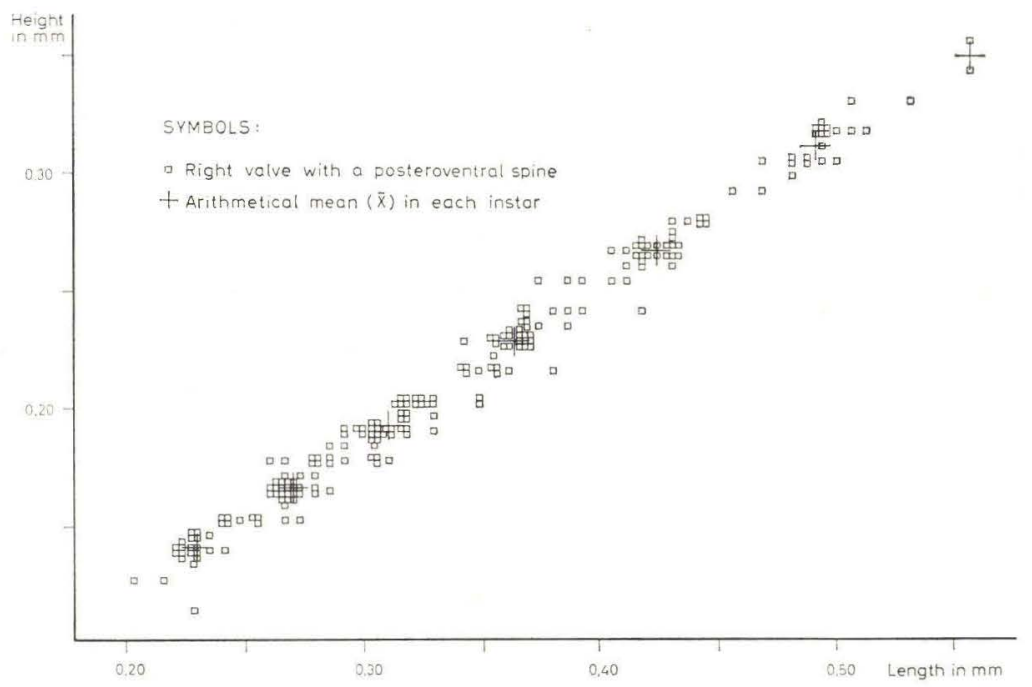

Text-fig. 8. Scattergram showing relations between numbers, lengths, and heights for right valves with a posteroventral spine of Ogmoconchella aspinata (DREXLER) 1958 from sample $\mathbf{M}_{21}$. These specimens are also figured at text-fig. 6 .

\section{Table I.}

Measurements (in mm). Rødby No. 1. Sample $\mathrm{M}_{21}$.

\begin{tabular}{|c|c|c|c|c|}
\hline \multirow{2}{*}{$\begin{array}{l}\text { Instar } \\
\text { Sex }\end{array}$} & \multicolumn{2}{|c|}{ A (adult) } & \multicolumn{2}{|c|}{ A-1 } \\
\hline & Males & Females & Males? & Females? \\
\hline \multicolumn{5}{|l|}{ Right valve: } \\
\hline Length $(\overline{\mathrm{X}}) \ldots \ldots \ldots \ldots \ldots \ldots$ & 0.63 & 0.56 & $?$ & 0.49 \\
\hline Length $(\mathrm{OR}) \ldots \ldots \ldots \ldots \ldots \ldots$ & 0.63 & $0.52-0.57$ & ? & $0.46-0.51$ \\
\hline Height $(\overline{\mathrm{X}}) \ldots \ldots \ldots \ldots \ldots \ldots$ & 0.39 & 0.34 & $?$ & 0.31 \\
\hline Height $(\mathrm{OR}) \ldots \ldots \ldots \ldots \ldots \ldots$ & 0.39 & $0.33-0.36$ & $?$ & $0.29-0.33$ \\
\hline \multicolumn{5}{|l|}{ Left valve and carapace: } \\
\hline Length $(\bar{X}) \ldots \ldots \ldots \ldots \ldots \ldots$ & 0.66 & 0.59 & 0.58 & 0.52 \\
\hline Length $(\mathrm{OR}) \ldots \ldots \ldots \ldots \ldots \ldots$ & $0.63-0.67$ & $0.53-0.61$ & $0.57-0.60$ & $0.47-0.58$ \\
\hline Height $(\overline{\mathrm{X}}) \ldots \ldots \ldots \ldots \ldots \ldots$ & 0.45 & 0.41 & 0.39 & 0.34 \\
\hline Height $(\mathrm{OR}) \ldots \ldots \ldots \ldots \ldots \ldots$ & $0.43-0.46$ & $0.39-0.42$ & $0.38-0.41$ & $0.32-0.37$ \\
\hline \multicolumn{5}{|l|}{ Carapace: } \\
\hline Breadth $(\overline{\mathrm{X}}) \ldots \ldots \ldots \ldots \ldots \ldots$ & 0.33 & 0.32 & 0.29 & 0.27 \\
\hline Breadth $(\mathrm{OR}) \ldots \ldots \ldots \ldots \ldots \ldots$ & $0.32-0.33$ & $0.30-0.33$ & $0.28-0.29$ & $0.25-0.28$ \\
\hline
\end{tabular}

$\overline{\mathrm{X}}=$ Arithmetical mean $=\frac{\Sigma \mathrm{X}}{\mathrm{N}}$, where $\mathrm{X}=$ any individual value of the variate, and $\mathrm{N}=$ Number of specimens. $\mathrm{OR}=$ observed range. 


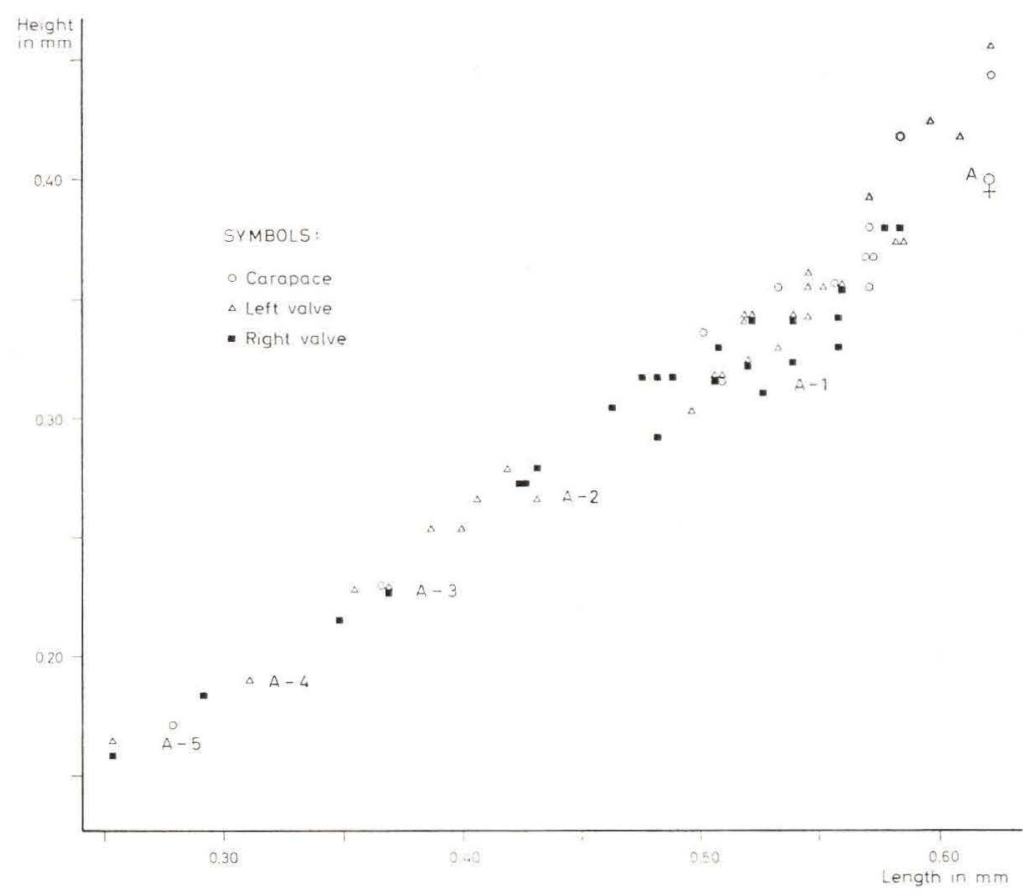

Text-fig. 9. Scattergram showing relations between numbers, lengths, and heights for valves and carapaces of Ogmoconchella aspinata (DREXLER) 1958 from sample II.

\begin{tabular}{|c|c|c|c|c|c|}
\hline A-2 & A-3 & A-4 & A-5 & A-6 & A-7 \\
\hline 0.42 & 0.36 & 0.31 & 0.27 & 0.23 & 0.19 \\
\hline $0.39-0.44$ & $0.34-0.39$ & $0.29-0.33$ & $0.25-0.29$ & $0.22-0.25$ & $0.19-0.20$ \\
\hline 0.27 & 0.23 & 0.19 & 0.17 & 0.14 & 0.13 \\
\hline $0.24-0.28$ & $0.20-0.25$ & $0.18-0.20$ & $0.15-0.18$ & $0.11-0.15$ & $0.13-0.14$ \\
\hline 0.44 & 0.38 & 0.32 & 0.28 & 0.24 & 0.19 \\
\hline $0.41-0.47$ & $0.35-0.41$ & $0.30-0.35$ & $0.25-0.30$ & $0.22-0.25$ & $0.18-0.20$ \\
\hline 0.29 & 0.24 & 0.20 & 0.17 & 0.15 & 0.13 \\
\hline $0.25-0.32$ & $0.22-0.27$ & $0.19-0.23$ & $0.15-0.20$ & $0.14-0.16$ & $0.11-0.14$ \\
\hline 0.23 & 0.20 & 0.16 & 0.14 & 0.13 & 11 \\
\hline $0.22-0.24$ & $0.18-0.22$ & $0.15-0.17$ & $0.13-0.16$ & $0.12-0.14$ & $0.10-0.12$ \\
\hline
\end{tabular}


Table II.

Measurements (in mm). Rødby No. 1. Sample $\mathrm{M}_{21}$.

\begin{tabular}{|c|c|c|c|c|c|c|c|c|}
\hline "Instar" & A & A-1 & A-2 & A-3 & A-4 & A-5 & A-6 & A-7 \\
\hline \multicolumn{9}{|c|}{ Right valve witk. a posteroventral spine: } \\
\hline Length $(\overline{\mathrm{X}}) \ldots$ & & 0.49 & 0.42 & 0.36 & 0.31 & 0.27 & 0.23 & \\
\hline Height $(\overline{\mathrm{X}}) \ldots$ & & 0.31 & 0.27 & 0.23 & 0.19 & 0.17 & 0.14 & \\
\hline \multicolumn{9}{|c|}{ Right valve without a posteroventral spine: } \\
\hline Length $(\overline{\mathrm{X}}) \ldots$ & 0.56 & 0.49 & 0.42 & & & & 0.22 & 0.19 \\
\hline Height $(\overline{\mathrm{X}}) \ldots$ & 0.35 & 0.30 & 0.27 & & & & 0.14 & 0.13 \\
\hline
\end{tabular}

$\overline{\mathrm{X}}=$ Arithmetical mean (see table I).

Table III

Growth Factor. Rødby No. 1. Sample $\mathrm{M}_{21}$.

\begin{tabular}{|c|c|c|c|c|c|c|c|}
\hline Between the instars & $\begin{array}{l}\text { A \& } \\
\text { A-1 }\end{array}$ & $\begin{array}{c}\text { A-1 \& } \\
\text { A-2 }\end{array}$ & $\begin{array}{c}\text { A-2 \& } \\
\text { A-3 }\end{array}$ & $\begin{array}{c}\text { A-3 \& } \\
\text { A-4 }\end{array}$ & $\begin{array}{c}\text { A-4 \& } \\
\text { A-5 }\end{array}$ & $\begin{array}{c}\text { A-5 \& } \\
\text { A-6 }\end{array}$ & $\begin{array}{l}\text { A-6 \& } \\
\text { A-7 }\end{array}$ \\
\hline Length of right valve.... & 1.16 & 1.15 & 1.16 & 1.17 & 1.17 & 1.17 & 1.18 \\
\hline Height of right valve .... & 1.12 & 1.16 & 1.17 & 1.18 & 1.15 & 1.18 & 1.10 \\
\hline Length of left valve..... & 1.14 & 1.18 & 1.18 & 1.18 & 1.16 & 1.17 & 1.22 \\
\hline Height of left valve ..... & 1.20 & 1.20 & 1.20 & 1.17 & 1.16 & 1.16 & 1.17 \\
\hline Breadth of carapace..... & 1.17 & 1.18 & 1.17 & 1.21 & 1.12 & 1.15 & 1.11 \\
\hline $\begin{array}{l}\text { Length of right valve } \\
\text { with a post. spine }\end{array}$ & & 1.16 & 1.17 & 1.17 & 1.15 & 1.18 & \\
\hline $\begin{array}{l}\text { Height of right valve } \\
\text { with a post. spine }\end{array}$ & & 1.17 & 1.17 & 1.18 & 1.16 & 1.18 & \\
\hline $\begin{array}{l}\text { Length of right valve } \\
\text { without a post. spine }\end{array}$ & 1.14 & 1.17 & & & & & 1.13 \\
\hline $\begin{array}{l}\text { Height of right valve } \\
\text { without a post. spine }\end{array}$ & 1.16 & 1.12 & & & & & 1.13 \\
\hline
\end{tabular}

in two centres, one containing most of the valves and the other containing a few of them. By drawing up the vertical cross-section (see text-fig. 6) it is possible to show the presence of dimorphism at least in the case of the largest instars. The representative of each separate instar is drawn with full line, while possible males are drawn with a dotted line. These latter differ from the firstmentioned in having a more rounded cross-section. The cross-section of the females and the larvae is more subtriangular. The "males" of the larval stadia belong to those few larvae in which it has not been possible to demonstrate any remnant of a posteroventral spine. This difference in the vertical crosssection is very slight, but when it is considered together with the above-mentioned element of sculpture, it would seem justified to assume the presence of 
dimorphism, either of sex or of species. The present author presumes that it is a sexual dimorphism, at least in the adults and the last larval stadium (A-1). The diagram for sample II (text-fig. 9) represents another environment of deposition but shows in the main the same pattern.

The growth factor is in sample $\mathrm{M}_{21}$ calculated between the consecutive instars (table III). Its average value is 1.17 . This corresponds to the growth factor in Cytherella and Gavelinella (REYMENT, 1960, p. 44).

Distribution: At Siebeldingen/Pfalz Ogmoconchella aspinata (DREXLER) is common in Lias Alpha 1, 2 \& 3 lower, while it occurs scattered in Alpha 3 upper (DreXLer, 1958). In Northern Germany it is common in Alpha 2 and occurs in Alpha 1 and 3, while in Southern Germany it is known only in Alpha 1 and 2 (KLINGLeR, 1962). In a boring at Gotha in Thüringen it occurs in large number in two clay zones which have, by means of among other things faunal analysis of the foraminifera, been referred to Lias Alpha (PietrzenuK, 1961).

\author{
Familia Polycopidae SARS 1866 \\ Genus Polycope SARS 1866 \\ Polycope No. 4065 \\ Plate XII, figs. 6 a-b.
}

1968. Polycope sp. 851 BruUn Christensen, pl. 23, fig. 6.

Material: Sample $\mathrm{M}_{12}: 1$ fragmentary carapace. Sample $\mathrm{M}_{13}: 1$ fragmentary carapace. Sample $\mathrm{M}_{15}: 3$ carapaces and 1 valve, as fragments. Sample $\mathrm{M}_{20}: 8$ carapaces and 2 valves, mostly as fragments. Sample $\mathrm{M}_{21}: 24$ carapaces and 4 valves, mostly as fragments.

Description: The carapace is small; it is nearly circular, as the height is in average a little larger than the length. Both valves are evenly arched.

The dorsal edge of the valve is straight to slightly convex. Both the anterior and the posterior cardinal angle are obtuse. The curve formed by the anterior, ventral and posterior edges is obliquely circular, as the ventral part of the valve is placed a little to the front of the dorsal part. The greatest height of the valve is at the median.

Each valve is evenly arched as a segment of a sphere and has its largest breadth at the middle. The right valve is larger than the left valve. The sculpture is fine and indistinct. It consists of partly concentric, often somewhat irregular furrows. These converge toward the ventral edge. The furrows are more distinct toward the edge of the valve and very faint in the central part of the valve. The hinge edge is straight. The left valve has posteriorly and anteriorly a ridge below a groove. In the right valve the rib is placed above the groove. The inner side of the valve, muscle scars and edge zone, could not be observed because of filling of pyrite. 
Measurements (in $\mathrm{mm}$ ):

\begin{tabular}{|c|c|c|c|c|}
\hline Sample & Valve & Length & Height & Breadth \\
\hline $\mathrm{M}_{20} \ldots \ldots \ldots \ldots \ldots \ldots$ & C. (Carapace) & 0.15 & 0.18 & 0.11 \\
\hline$-\ldots \ldots \ldots \ldots \ldots \ldots \ldots$ & C. & 0.14 & $0.14(?)$ & 0.09 \\
\hline$\ldots \ldots \ldots \ldots \ldots \ldots$ & C. & 0.14 & 0.14 & 0.09 \\
\hline$-\ldots \ldots \ldots \ldots \ldots \ldots \ldots$ & C. & 0.16 & $0.17(?)$ & 0.09 \\
\hline $\mathrm{M}_{21} \ldots \ldots \ldots \ldots \ldots \ldots$ & C. & 0.17 & 0.17 & 0.10 \\
\hline$-\ldots \ldots \ldots \cdots \cdots \cdots$ & C. & 0.15 & 0.15 & 0.09 \\
\hline$-\ldots \ldots \cdots \cdots \cdots$ & C. & 0.14 & 0.15 & $0.08(?)$ \\
\hline$-\ldots \ldots \cdots \cdots \cdots \cdots$ & L. (Left) & 0.15 & 0.15 & \\
\hline
\end{tabular}

Remarks: Polycope No. 4065 is identical with P. sp. 851 BrUUn CHRISTENSEN. It seems to differ, by its small size and very fine sculpture, from other known species. The material available is too poorly preserved to allow a final classification.

Distribution: In the Øresund boreholes Polycope sp. 851 is found in that part of Döshult beds which is referred to Lias Alpha (BRUUn CHRISTENSEN, 1968). 


\title{
DANSK SAMMENDRAG
}

\author{
INDLEDNING
}

I indledningen gives en kort oversigt over tidligere arbejder vedrørende boringen Rødby No. 1. Den stratigrafiske inddeling af Rhæt-Lias afsnittet, præsenteret hos både Nørvang (1957) og Sorgenfrei \& Buch (1964), er baseret på P. H. BAADSGAARD's undersøgelser af makrofossiler:

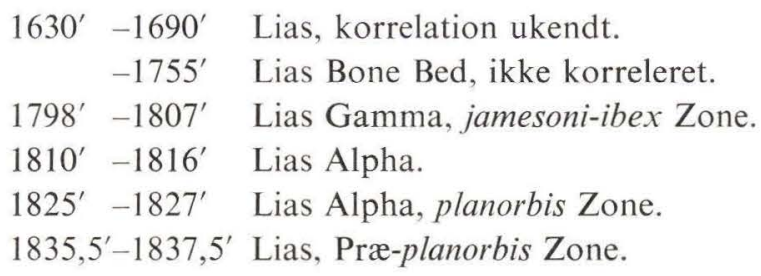

\section{MATERIALER og METODER}

Hele det undersøgte interval er kærneboret. De udtagne prøver er nummereret fortløbende som prøve $\mathbf{M}_{1}-\mathbf{M}_{113}$. Disses placering i profilet er vist på pl. XVII. Til bedømmelse af ostracodfaunaen har cand. mag. I. BANG (D. G. U.) venligst stillet prøverne I $\left(1802,3^{\prime}\right)$ og II $\left(1803,3^{\prime}\right)$ til rådighed. Alle dybdeangivelser, der er opgivet $\mathrm{i}$ engelske fod i dette arbejde, er målt under Kelly Bushing (se pl. XVII).

\section{STRATIGRAFISK ANALYSE}

\section{Megasporefloraens sammensatning:}

Megasporefloraen består i det undersøgte interval af boringen Rødby No. 1 totalt af 15 arter. Af disse er de 12 tidligere beskrevet fra Rhæt-Lias aflejringer, medens to former er nye. En af disse er opstillet som ny art, mens den anden kun er beskrevet og diskuteret, da materialet var for ringe til en nyopstilling. Endelig er en spore, sandsynligvis af Karbon oprindelse, fundet øverst i intervallet.

Den vertikale udbredelse af de enkelte megasporearter i det undersøgte interval er vist på pl. XVII. Den kvantitative forekomst af sporerne i de enkelte prøver er ikke anført på tavlen, men under de respektive beskrivelser.

Floraen grupperer sig, som det fremgår af pl. XVII, i to sporeselskaber, der overlapper hinanden $i$ et forholdsvis kort interval, svarende til prøverne $\mathrm{M}_{50}$ - 
$\mathbf{M}_{52}$. Denne sammenblanding afspejler formodentlig en tilsvarende, kortvarig overgangsperiode i de sporeproducerende plantesamfund, hvorunder en flora har fortrængt en anden. En sammenblanding som følge af sedimentationsvilkårene afvises, da en tilsvarende blanding af ostracodfaunaerne ikke er konstateret (jf. pl. XVII).

Det ældste af de to sporeselskaber omfatter 8 tidligere beskrevne arter:

Calamospora rhaetica (JUNG) POTONIÉ

Trileites cf. pedinacron (HARRIS) POTONIÉ

Trileites pinguis (HARris) POTONIÉ

Maexisporites $\mathrm{cf}$. misellus MARCINKIEWICZ

Verrutriletes utilis (MARCINKIEWICZ) MARC.

Bacutriletes tylotus (HARRIS) POTONIÉ

Horstisporites rexargenteus (HARRIS) POTONIÉ

Minerisporites ales (HARRIS) POTONIÉ

samt to nye:

Bacutriletes reticuliferus $\mathrm{n}$. $\mathrm{sp}$.

Horstisporites sp., megaspore type nr. 5

Trileites pinguis (HARRIS) РоT. er den dominerende og karakteriserende sporeart i dette selskab, der forekommer i prøveintervallet $\mathrm{M}_{50}-\mathrm{M}_{103}$. I de nederste sporeholdige prøver er den dog sparsomt repræsenteret. Disse domineres af Minerisporites ales (HARRIS) POT. der modsat viser en vigende tendens opefter. Trileites cf. pedinacron (HARRIS) POT., Verrutriletes utilis MARCINKIEWICZ og Bacutriletes tylotus (HARRIS) РОT. forekommer jævnlig i de øvre prøver, mens de resterende må betegnes som sjældne.

De sporeholdige prøver er ikke jævnt fordelt i ovennævnte interval, men grupperer sig i vekslende sporeholdige og sporefattige afsnit. Følgende afsnit lader sig udskille som sporeholdige: $\mathrm{M}_{50}-\mathrm{M}_{53}, \mathrm{M}_{61^{-}} \mathrm{M}_{71}, \mathrm{M}_{75}, \mathrm{M}_{95}$ og $\mathrm{M}_{100^{-}}$ $M_{103}$, mens de resterende afsnit er sporefri eller kun indeholder ganske få sporer. Sporeselskabet kaldes i det følgende $T$. pinguis selskabet, en benævnelse der allerede er benyttet i litteraturen (WILL, 1969).

Det yngre sporeselskab omfatter 4 arter, der alle er kendt fra tidligere beskrivelser:

Verrutriletes franconicus JUNG

Horstisporites areolatus (HARRIS) POTONIÉ

Horstisporites harrisi (MURRAY) POTONIÉ

Nathorstisporites hopliticus JUNG

Dette sporeselskab, i det følgende betegnet $N$. hopliticus selskabet efter den dominerende sporeart, har en vertikal udbredelse svarende til prøveintervallet $\mathrm{M}_{4}-\mathrm{M}_{52}$. N. hopliticus JUNG er langt den hyppigste spore i alle de sporeholdige prøver, mens de øvrige kun forekommer sparsomt, Verrutriletes franconicus dog med nogen hyppighed i de øverste prøver. 
To særligt sporeholdige afsnit lader sig udskille i prøveintervallet $\mathrm{M}_{4}-\mathrm{M}_{49}$ : $\mathrm{M}_{4}-\mathrm{M}_{7}$ og $\mathrm{M}_{19}-\mathrm{M}_{33}$. Afsnittene er inhomogene, idet visse prøver er rige på sporer $\left(M_{4}\right.$ og $\left.M_{25}\right)$ medens nogle er sporefri $\left(M_{21}, M_{24}, M_{26}, M_{28}\right.$ og $\left.M_{29}\right)$. De øvrige prøver har et meget ringe eller intet sporeindhold. I intervallet $\mathrm{M}_{50^{-}}$ $\mathrm{M}_{52}$, der ovenfor er indregnet i de sporeholdige afsnit, fandtes kun få eksemplarer fra $N$. hopliticus selskabet.

På basis af megasporefloraens opdeling i to selskaber lader det sig gøre at opdele det undersøgte interval i to assemblage zoner, nederst $T$. pinguis Assemblage Zonen (1858'-2320') og øverst $N$. hopliticus Assemblage Zonen (1561$1858^{\prime}$ ). Nederste respektive øverste grænse for de to assemblage zoner er lagt, hvor megasporer indeholdt i de nævnte selskaber første gang viser sig og hvor de forsvinder. Grænsen mellem de to assemblage zoner er draget under den ældste prøve indeholdende arter fra $N$. hopliticus selskabet $\left(\mathrm{M}_{52}\right)$ ved $1858^{\prime}$. Derved kommer $N$. hopliticus Assemblage Zonen til at rumme sporer fra $T$. pinguis selskabet ( $T$. cf. pedinacron, $T$. pinguis, V. utilis, B. reticuliferus, B. tylotus) i den nedre del.

\section{Stratigrafisk korrelation:}

T. pinguis Assemblage Zonen: De tidligere i litteraturen beskrevne megasporearter, som forekommer i denne assemblage zone, har med undtagelse af Bacutriletes tylotus (HARRIS) POTONIÉ, en vertikal udbredelse begrænset til Lepidopteris ottonis Zonen eller dele af denne. Enkelte arter forekommer tillige i den basale del af Thaumatopteris schenki Zonen eller en overgangszone til denne (jf. beskrivelser, afbildninger m.v. fra Grønland (HARRIS, 1926, 1935, 1937), Sverige (Brotzen, 1950; Lundblad, 1950, 1959), Polen (MarcinKIEWICZ, 1962, 1969), Nordtyskland (REINHARDT, 1963; Wicher, 1942, 1951, 1957; Will, 1969), Sydtyskland (Jung, 1960), Holland (Ten Dam, 1947) og England (Lewarne \& Pallot, 1957)). B. tylotus (Harris) Potonié, er i Sydtyskland (Franken) kun fundet i Thaumatopteris schenki Zonen, mens den i Nordeuropa og i Grønland har en vertikal udbredelse begrænset til Lepidopteris ottonis Zonen og den basale del af Thaumatopteris schenki Zonen.

Det må derfor formodes, at det af $T$. pinguis Assemblage Zonen begrænsede interval, kan henføres til Rhæt, og denne antagelse støttes af et fund af Lepidopteris ottonis (Goepp.) Schimp. i prøve $\mathrm{M}_{87}$ (se pl. X, figs. 4, 5.).

T. pinguis Assemblage Zonen kan på grundlag af megasporearternes vertikale fordeling og profilets lithologiske sammensætning, som den er udtrykt i SoRGENFREI \& BUCH (1964) og LARSEN (1966), korreleres med Rhätkeuper, der omfatter Contorta Schichten overlejret af Triletes Schichten, i Nordvesttyskland (jf. WILL, 1969). Det bør her oplyses, at WILL's betegnelser Rhätkeuper + Präplanorbis Schichten svarer til M.-Ø. Rhæt i WICHER's inddeling af 1951 (WILL, fig. 40).

På SP-kurven for Rødby No. 1 (LARSEN, 1966, pl. XV), svarer intervallet 
$1858^{\prime}-2103^{\prime}$ til WiLL's Triletes-Anomalie, medens intervallet $2170^{\prime}-2260^{\prime}$ kan korreleres til Haupt-Anomalie ("Mittelrhät Hauptsandstein") (jf. WILL, 1969, pl. 4), hvorfor det må antages, at $T$. pinguis Assemblage Zonen i Rødby No. 1 omfatter et interval svarende til Contorta Schichten og Triletes Schichten i Nordvesttyskland.

Denne formodning støttes af en sammenligning mellem den nordvesttyske og den danske megaspore flora, idet artsfordelingsmønstret i Rødby afspejler forholdene i Nordvesttyskland, hvor de øvre Triletes Schichten rummer en artsrig flora (totalt 20 arter), mens de nedre Contorta Schichten karakteriseres ved et artsfattigt selskab (totalt 6 arter). De dominerende arter i WILL's pinguisAssemblage, $T$. pinguis (Harris) Potonié, $V$. utilis Marcinkiewicz ( $=T$. wicheri WiLL), T. pedinacron (HARris) Potonié, B. tylotus (HARris) PotoniÉ og V. litchi (Harris) Potonié, genfindes med undtagelse af $V$. litchi, i $T$. pinguis Assemblage Zonen, hvor de alle er hyppigt forekommende.

Medens det således synes godtgjort, at $T$. pinguis Assemblage Zonen kan korreleres til Rhätkeuper i Nordvesttyskland, er en underopdeling af zonen $\mathrm{i}$ to intervaller svarende til Contorta Schichten og Triletes Schichten problematisk, da prøverne i det relevante grænseinterval er fossilfrie $\left(\mathrm{M}_{76}-\mathrm{M}_{85}\right)$. Forfatteren foreslår at grænsen drages ved bunden af den øvre sandede lagserie, svarende til dybden $2115^{\prime}$ (ca. $641 \mathrm{~m}$ under terræn).

Korrelationen til Nordvesttyskland har til dels bekræftet den tidligere stratigrafiske tolkning af boringen Rødby No. 1 (Sorgenfrei \& BUCH, 1964; LARSEN, 1966), hvor afsnittet $1837,5^{\prime}-2350^{\prime}$ henføres til Rhæt, idet intervallet $2320^{\prime}-$ $2350^{\prime}$ over de karbonatrige Mellem Keuperlag, lithologisk knytter sig til T. pinguis Assemblage Zonens bjergarter. SORGENFREI \& BUCH's øvre afgrænsning af Rhæt, må dog anses for tvivlsom, da den tilsyneladende kun bygger på forekomsten af "Megaspores with circular fold" i prøverne under 1837,5'. Analysen af megaspore floraen og ostracod faunaen (p. 55) sandsynliggør en øvre afgrænsning af Rhæt ved $1858^{\prime}$ (mellem prøve $\mathrm{M}_{52}$ og $\mathrm{M}_{53}$ ), hvorved grænsen svarer til T. pinguis Assemblage Zonens øvre grænse.

N. hopliticus Assemblage Zonen: De karakteristiske arter i denne zone, Nathorstisporites hopliticus JUNG og Verrutriletes franconicus JUNG, har i typeområdet Franken, Sydtyskland, en vertikaludbredelse svarende til Thaumatopteris schenki Zonen. Ved Sassendorf overlejres de planteførende, men megasporefri, lag repræsenterende den yngre flora (svarende til Thaumatopteris floraen) af marine lag med Schlotheimia angulata (Lias Alpha 2), hvilket begrunder, at den yngre flora, og dermed $N$. hopliticus selskabet, i Franken ikke antages at være yngre end Hettangien (jf. JUNG, 1960; Harris, 1937; LundBLAD, 1959). Medens $V$. franconicus hidtil kun er beskrevet fra én lokalitet uden for typeområdet, på Bornholm i selskab med N. hopliticus (GRY, 1969), har N. hopliticus en stor geografisk udbredelse (Grønland, Nord- og Mellemeuropa, Sydaustralien) og den regnes almindeligvis som et brugbart ledefossil for Thaumatopteris schenki Zonen (diskuteret i LundBLAD, 1956). De to øvrige 
arter i N. hopliticus selskabet, Horstisporites areolatus (HARrIs) POTONIÉ og Horstisporites harrisi (MURRAY) POTONIÉ $(=H$. semireticulatus JUNG = Erlansonisporites reticulatus (ZERNDT) MARCINKIEWICZ), har en relativ stor vertikal udbredelse, Nedre-Mellem Jura, og har derfor begrænset stratigrafisk værdi (jf. JunG, 1960; Marcinkiewicz, 1960, 1962; Harris, 1961 m. fl.). Den dominerende forekomst af $N$. hopliticus, samt indholdet af $V$. franconicus i de øverste prøver, betinger derfor en datering af $N$. hopliticus Assemblage Zonen til Hettangien.

WILl (1969) ækvivalerer grænsen mellem Präplanorbis Schichten og Psiloten Schichten med overgrænsen for forekomsten af $T$. pinguis selskabet, idet dette selskab i noget afsvækket form fortsætter op i det basale Lias, hvor det afløses af et $N$. hopliticus selskab uden at en sammenblanding mellem de to sporeselskaber er konstateret (jf. WILL, 1969, p. 133 og pp. 23-33). Da forekomsten af $N$. hopliticus er ringe i "blandingsintervallet" $\left(\mathrm{M}_{50}-\mathrm{M}_{52}\right)$, må det formodes at dette interval kan korreleres til Präplanorbis Schichten i Nordvesttyskland. Dette bekræftes til en vis grad i SORGENFreI \& BuCH (1964), hvor et interval mellem prøve $\mathrm{M}_{49}$ og $\mathrm{M}_{50}\left(1835^{\prime}-1837,5^{\prime}\right)$ er henført til "Lias, (pre-planorbis zone)".

Sammenkædes tolkningsresultaterne af megasporeanalysen, kan nedenstående kronostratigrafiske inddeling af Rhæt-Lias afsnittet i Rødby No. 1 boringen opstilles, idet en bedømmelse af Sorgenfrei \& BuCH's fortolkning af intervallet $1549^{\prime}-1835^{\prime}$ er udeladt (diskuteres i ostracod-afsnittet).

$$
\begin{array}{ll}
469 \mathrm{~m}-556 \mathrm{~m}\left(1549^{\prime}-1835^{\prime}\right) & \text { Lias Alpha 1-2 } \\
556 \mathrm{~m}-563 \mathrm{~m}\left(1835^{\prime}-1858^{\prime}\right) & \text { Lias, Præ-planorbis Zone } \\
563 \mathrm{~m}-641 \mathrm{~m}\left(1858^{\prime}-2115^{\prime}\right) & \text { Ovre Rhæt } \\
641 \mathrm{~m}-713 \mathrm{~m}\left(2115^{\prime}-2350^{\prime}\right) & \text { Mellem Rhæt }
\end{array}
$$

Dybderne er angivet i metre under terræn og i engelske fod under Kelly Bushing (jvf. pl. XVII).

\section{Ostracodfaunaens sammensatning:}

Det undersøgte interval kan på grundlag af ostracodindholdet inddeles i to afsnit: nederst intervallet med Øvre Trias ostracoder, og øverst intervallet med Nedre Jura ostracoder. Grænsen mellem lisse to afsnit findes mellem prøverne $\mathrm{M}_{52}$ og $\mathrm{M}_{53}$ og er fastlagt ved $1858^{\prime}$.

I prøverne $\mathrm{M}_{53}, \mathrm{M}_{105}$ og $\mathrm{M}_{107}$ er der fundet få hele skaller og talrige fragmenter af en tyndskallet form, der knytter sig til slægterne Darwinula BRADY \& Robertson (1885) og Darwinuloides Mandelstam (1956). I en kommende afhandling om ostracodfaunaer fra Keuper og Rhæt i de danske aflejringer vil denne form blive beskrevet af BruUn Christensen \& Michelsen.

Nedre jurassiske ostracoder er fundet i prøverne: $M_{8}, M_{10}-M_{15}, M_{18}, M_{20}$, $\mathrm{M}_{21}, \mathrm{M}_{27}, \mathrm{M}_{34}, \mathrm{M}_{35}, \mathrm{M}_{41}-\mathrm{M}_{43}, \mathrm{M}_{45}, \mathrm{M}_{47}, \mathrm{M}_{49}, \mathrm{M}_{51}$ og $\mathrm{M}_{52}$. I de fleste af disse 
prøver er ostracodfaunaen karakteriseret ved forekomsten af Ogmoconchella aspinata (DREXLER). Hele ovennævnte interval, 1588'-1858', er efter denne art benævnt $O$. aspinata Assemblage Zonen. De accessoriske arter er:

Procytheridea medioreticulata $\mathrm{n}$. sp.

Lophocythere elegans DREXLER

Macrocypris No. 4023

Polycope No. 4065

Paradoxostoma ? cf. P. ? fusiformis DreXLER

Stenestroemia? roedbyensis $\mathrm{n}$. sp.

Lophocythere No. 4061

Lophocythere sp. (4076)

Procytheridea sp. (4081)

O. aspinata er den absolut dominerende form i den nedre del af profilet, med undtagelse af prøverne $\mathrm{M}_{51}$ og $\mathrm{M}_{52}$. Disse to prøver præges helt af ret fragmentariske larveskaller, der er henført til arten $P$. medioreticulata. Den øvre del af intervallet, prøverne $\mathrm{M}_{8}, \mathrm{M}_{10}-\mathrm{M}_{13}, \mathrm{og} \mathrm{M}_{15}$, domineres ligeledes af denne art, medens $O$. aspinata er vigende. $L$. elegans er en fremtrædende art i prøve $\mathrm{M}_{8}$. Prøverne $\mathrm{M}_{20}$ og $\mathrm{M}_{21}$ afviger fra de øvrige ved at være rig på både arter og individer, $O$. aspinata dominerer her med ca. 70\%. Iøvrigt karakteriseres disse prøver ved $S$. ? roedbyensis, der her har sin maximumforekomst, og ved Macrocypris No. 4023.

\section{Stratigrafisk korrelation:}

I det overvejende sandede afsnit under $1858^{\prime}$ er ostracoderne kun sparsomt repræsenteret. Faunaen i de tre prøver, $\mathrm{M}_{53}, \mathrm{M}_{105} \mathrm{og} \mathrm{M}_{107}$, må antages at være af Øvre Trias alder. I de nordeuropæiske sedimentationsbassiner er former knyttet til slægten Darwinula karakteristiske for dele af Rhæt og Keuper (se BruUn Christensen, 1962, UrLichs, 1966 og Wicher, 1957).

De fleste af de arter, der forekommer i $O$. aspinata Assemblage Zonen, er kendt fra aflejringer henført til Lias Alpha. $O$. aspinata er i Tyskland hyppig i $S$. angulata Zonen (Lias Alpha 2), men kendes iøvrigt fra både $P$. planorbis Zonen (Lias Alpha 1) og A. bucklandia Zonen (Lias Alpha 3). I den danske boring, Gassum No. 1, forekommer denne art i hele det afsnit, der på basis af ammonitfaunaen er henført til Lias Alpha. Blandt de accessoriske arter i $O$. aspinata Assemblage Zonen er L. elegans, P. medioreticulata (= Ostracod No. 108 KLINGLER) og $P$. ? fusiformis af stratigrafisk betydning. De er i Tyskland kendt fra $S$. angulata Zonen og nedre del af $A$. bucklandia Zonen. $P$. medioreticulata er i boringen Gassum No. 1 kendt fra hele Lias Alpha. $L$. elegans er i samme boring kun fundet i den øvre del af de lag, der med nogen usikkerhed er henført til Nedre Sinemurien (se NøRVANG, 1957, p. 313). I Øresundsboringerne er sidstnævnte art sammen med $P$. ? cf. $P$. ? fusiformis 
og Polycope No. 4065 kendt fra den del af Döshult lagene, der er henført til Lias Alpha (Bruun Christensen, 1968). Macrocypris No. 4023 er i boringen Gassum No. 1 almindelig i de lag, der er bestemt til Nedre Sinemurien og øverste Hettangien.

Den udprægede forskel mellem faunaerne i prøverne $\mathrm{M}_{52}$ og $\mathrm{M}_{53}$ markerer grænsen mellem intervallet med Øvre Trias ostracoder og $O$. aspinata Assemblage Zonen. På dette grundlag er Rhæt-Lias grænsen i boringen Rødby No. 1 lagt ved $1858^{\prime}$ (se pl. XVII). Den kvantitative fordeling af $O$. aspinata med et maximum midt $\mathrm{i}$ intervallet danner basis for en korrelation til tyske aflejringer med faunaer fra Lias Alpha 1, $2 \& 3$. Forekomsten af $P$. medioreticulata nederst $\mathrm{i}$ afsnittet (prøverne $\mathrm{M}_{51}$ og $\mathrm{M}_{52}$ ) står i modsætning til dens normale udbredelse $\mathrm{i}$ andre lokaliteter. Disse prøver må dog efter forfatterens mening høre til den nederste del af Lias Alpha i denne boring. Den vigende tendens hos $O$. aspinata i den øvre del af $O$. aspinata Assemblage Zonen, sammenholdt med tilstedeværelsen af arter som P. medioreticulata og L. elegans, tillader en korrelation til Lias Alpha 2 \& 3 nedre. Det synes hermed muligt at korrelere indirekte til Hettangien og nedre del af Nedre Sinemurien.

På grundlag af makrofossiler er afsnittet $1835^{\prime}-1837,5^{\prime}$ tidligere blevet henført til Præ-planorbis Zonen (se Sorgenfrei \& BuCH, 1964). Dette afsnit ligger umiddelbart over prøverne $\mathrm{M}_{51}$ og $\mathrm{M}_{52}$, der indeholder den afvigende ostracodfauna. Det er derfor sandsynligt at Præ-planorbis Zonen skal omfatte hele afsnittet $1835^{\prime}-1858^{\prime}$. Forekomsten af Psiloceras planorbis (SOWERBY) i intervallet $1825^{\prime}-1827^{\prime}$ (se SORGENFREI \& BuCH, 1964) støtter ovenstående vurdering baseret på ostracodfaunaen. P. planorbis Zonen antages på grundlag af ostracodfaunaen at omfatte prøverne $\mathrm{M}_{44}-\mathrm{M}_{49}$. Ifølge SorgEnfrei \& Buch (1964) henføres afsnittet $1798^{\prime}-1807^{\prime}$ på basis af makrofossiler til Lias Gamma. Af disse fossiler er kun én art, Beaniceras cf. centaurus (D'ORBIGNY) kendt fra Pliensbachien. Det fundne eksemplar af denne art er ifølge SORGENFrEI \& Buch usikkert bestemt. En anden art, Paleoneilo gatalea (D'OrBIGNY), kendes i Nordvesttyskland og England fra Lias Alpha-Epsilon. De øvrige arter er i Skåne og på Bornholm kendt fra aflejringer, der henføres til Lias Gamma. O. aspinata dominerer i prøverne $\mathrm{I}, \mathrm{M}_{43} \mathrm{og} \mathrm{II}$, der falder indenfor dette afsnit $\left(1798^{\prime}-1807^{\prime}\right)$. Heraf fremgår det, at de aflejringer, der hos Sorgenfrei \& BucH (1964) blev henført til Lias Gamma, indeholder ostracoder fra Lias Alpha.

På basis heraf kan Lias afsnittet i boringen Rødby No. 1 kronostratigrafisk inddeles på følgende måde:

Prøve $M_{8}-M_{11}$ (480-485 m): Øvre Hettangien eller Nedre Sinemurien.

Prøve $\mathrm{M}_{12}-\mathrm{M}_{43}(485-547 \mathrm{~m})$ : Øvre Hettangien.

Prøve $\mathrm{M}_{44}-\mathrm{M}_{52}(547-563 \mathrm{~m})$ : Nedre Hettangien.

Dybderne er angivet i metre under terrænoverfladen (jf. pl. XVII og SoRGENFREI \& BUCH, 1964). 


\section{REFERENCES}

Brady, G. S., 1868. A synopsis of the Recent British Ostracoda. - Intell. Observer. - London. Brotzen, F., 1950. De geologiske resultaten från borrningarna vid Höllviken. Del II, Undre Kritan och Trias. - Sveriges Geologiska Undersökning, ser. C, No. 505. - Stockholm.

Christensen, O. BruUn, 1962. Ostracodtyper fra Keuper-Rhaet lagserien i dybdeboringerne ved Harte og Ullerslev. - Medd. Dansk Geol. Foren. bd. 15, 1, pp. 90-99. København.

- 1968. Some deposits and microfaunas from the Upper Jurassic in Scania. - Sveriges Geologiska Undersökning, ser. C., No. 632. - Stockholm.

- 1968. In Larsen, G., Christensen, O. Bruun, Bang, I. \& Buch, A., 1968. Øresund. Helsingør-Hälsingborg Linien. - Danmarks Geologiske Undersøgelse, rapp. No. 1. København.

DAM, A. TEN, 1947. De verspreiding van Boven-Rhaet in Nederland. - Geologie en Mijnbouw, N. S., 9EJR, No. 11, pp. 220-223. - 's Gravenhage.

Dettmann, M. E., 1961. Lower Mesozoic megaspores from Tasmania and South Australia. Micropaleontology, vol. 7, No. 1, pp. 71-86. - New York.

Dijkstra, S. J., 1949. Megaspores and some other fossils from the Aachenian (Senonian) in South Limburg, Netherlands. - Meded. Geol. Sticht. N. S., No. 3, pp. 19-32. Heerlen.

- 1951. Wealden Megaspores and their stratigraphical value. - Ibidem, No. 5, pp. 7-22.

Dijkstra, S. J. \& Piérart, P., 1957. Lower Carboniferous Megaspores from the Moscow Basin. - Ibidem, No. 11, pp. 5-19.

Drexler, E .,1958. Foraminiferen und Ostracoden aus dem Lias $\alpha$ von Siebeldingen/Pfalz. - Geol. Jb., Bd. 75, pp. 475-554. - Hannover.

Dreyer, E., 1967. Mikrofossilien des Rät und Lias von SW-Brandenburg. - Jb. Geol. Bd. 1, pp. 491-531. - Berlin.

Erdtman, G., 1969. Handbook of Palynology. - København.

Fischer, S., 1855. Beitrag zur Kenntniss der Ostracoden. - K. Bayer. Akad. Wiss., München, Math. - Physik. C 1, Abh. - München.

GrüNDEL, J., 1964. Zur Gattung Healdia (Ostracoda) und zu einigen verwandten Formen aus dem unteren Jura. - Geologie, Jahrg. 13, H. 4, pp. 456-475. - Berlin.

GRY, H., 1969. Megaspores from the Jurassic of the Island of Bornholm, Denmark. Medd. Dansk Geol. Foren., bd. 19, 1, pp. 69-89. - København.

Harris, T. M., 1926. The Rhaetic flora of Scoresby Sound East Greenland. - Medd. Grønland, bd. 68, pp. 43-148. - København.

- 1935. The fossil flora of Scoresby Sound East Greenland. Part 4: Ginkgoales, Coniferales, Lycopodiales and isolated fructifications. - Ibidem, bd. 112, No. 1.

- 1937. The fossil flora of Scoresby Sound East Greenland. Part 5: Stratigraphic relations of the plant beds. - Ibidem, bd. 112, No. 2 .

- 1946. Liassic and Rhaetic plants collected in 1936-38 from East Greenland. - Ibidem, bd. 114, No. 9.

- 1961. The Yorkshire Jurassic flora: I, Thallophyta-Pteridophyta. - London. 
Jones, T. R. \& Sherborn, C. D., 1888. On some Ostracoda from the Fullers-earth oolite and Bradford Clay. - Bath Nat. Hist. and Antiquarian Field Club, Proc., vol. 6, No. 3. Bath.

Jung, W., 1958. Zur Biologie und Morphologie einiger disperser Megasporen, vergleichbar mit solchen von Lycostrobus scotti, aus dem Rhät-Lias Frankens. - Geol. Bl. No-Bayern, Bd. 8, 3, pp. 114-129. - Erlangen.

- 1960. Die dispersen Megasporen der fränkischen Rhät-Lias Grenz-schichten. - Palaeontographica, Bd. 107 Abt. B, pp. 127-170. - Stuttgart.

Klingler, W., 1962. Lias Deutschlands. - In Simon \& Bartenstein, 1962. Leitfossilien der Mikropaläontologie, pp. 73-122, - Berlin.

Klingler, W. \& Neuweiler, F., 1959. Leitende Ostracoden aus dem deutschen Lias $\beta$. Geol. Jb., Bd. 76, pp. 373-410. - Hannover.

LARSEN, G., 1966. Rhaetic-Jurassic-Lower Cretaceous Sediments in the Danish Embayment. (A Heavy-Mineral Study). - Danmarks Geologiske Undersøgelse, II. Række, No. 91. - København.

Lewarne, G. C. \& Pallot, J. M., 1957. Mesozoic plants from fissures in the Carboniferous Limestone of South Wales. - Ann. \& Mag. Nat. Hist., zoology, botany, and geology, vol. 10, 12th ser., No. 109, pp. 72-79. - London.

Lundblad, A. B., 1950. Studies in the Rhaeto-Liassic floras of Sweden. I. Pteridophyta, Pteridospermae, and Cycadophyta from the mining district of NW-Scania. - Svenska Vet. Akad. Handl. ser. 4, bd. 1, No. 8. - Stockholm.

- 1956. On the stratigraphical value of the megaspores of Lycostrobus scotti. Preliminary report of some new finds and their interpretation. - Sveriges Geologiska Undersökning, ser. C, No. 547. - Stockholm.

- 1959. Rhaeto-Liassic floras and their bearing on the stratigraphy of Triassic-Jurassic rocks. - Stockh. Contr. Geol. vol. III :4. - Stockholm.

Marcinkiewicz, T., 1960. [Megaspore analysis of Jurassic sediments near Gorzów Ślạski - Praszka (Cracow - Wieluń region)]. - Kwart. Geol., tom. 4, 3, pp. 713-734 (in Polish w/ English resumé). - Warszawa.

- 1962. [Rhaetian and Lias megaspores from bore-hole Mechowo near Kamień Pomorski and their stratigraphical value]. - Inst. Geol., odbitka z prac tom. 30, cz. 3, pp. 469-494 (in Polish w/English resumé) - Warszawa.

- 1969. [Boundary between Rhaetic and Lias in the extra-carpatian area of Poland, determined on floristic basis]. - Kwart. Geol., tom. 13, No. 1, pp. 100-114 (in Polish w/ English resumé). - Warszawa.

Marcinkiewicz, T., Orfowska, T. \& Rogalska, M., 1960. [Age of the Upper Helenów Beds (Lias) in view of megaspores and microspore investigations (geological section Gorsów Ślạski - Praszka)]. - Ibidem, tom. 4, No. 2, pp. 386-398 (in Polish W/English resumé).

Miner, E. L., 1932. Megaspores ascribed to Selaginellites, from the Upper Cretaceous coals of Western Greenland. - Journ. Wash. Acad. Sci. vol. 22, No. 18, 19, pp. 497-506. - Baltimore.

Murray, N., 1939. Microflora of the Upper and Lower Estuarine Series of the East Midlands. - Geol. Mag. vol. 76, No. 905, pp. 478-488. - London.

Nathorst, A. G., 1908. Lycostrobus scotti, eine grosse Sporophyllähre aus den rätischen Ablagerungen Schonens. - Svenska Vet. Akad. Handl., bd. 43, No. 3. - Stockholm.

Neale, J. W., 1964. Some factors influencing the distribution of Recent British Ostracoda. - Pubbl. staz. zool. Napoli 33 suppl., pp. 247-307.

Nørvang, A., 1957. The Foraminifera of the Lias Series in Jutland, Denmark. - Medd. Dansk Geol. Foren., bd. 13, 5, pp. 279-409. - København.

Pettitt, J. M., 1966. Exine structure in some fossil and recent spores and pollen as revealed by light and electron microscopy. - Bull. Brit. Mus., Geol., vol. 13, No. 4 - London. 
Pietrzenuk, E., 1961. Zur Mikrofauna einiger Liasvorkommen in der Deutschen Demokratischen Republik. - Freiberger Forsch.-H., C 113. - Berlin.

Potonié, R., 1956. Synopsis der Gattungen der Sporae dispersae, I. Teil: Sporites. - Beih. Geol. Jb., 23. - Hannover.

- 1958. Synopsis der Gattungen der Sporae dispersae, II. Teil: Sporites (Nachträge), Saccites, Aletes, Praecolpates, Polyplicates, Monocolpates. - Ibidem, H. 31.

- 1960. Synopsis der Gattungen der Sporae dispersae, III. Teil: Nachträge Sporites, Fortsetzung Pollenites. - Ibidem, H. 39.

- 1966. Synopsis der Gattungen der Sporae dispersae, IV. Teil : Nachträge zu allen Gruppen (Turmae). - Ibidem, H. 72.

Potoní,, R. \& Kremp, G., 1955. Die Sporae Dispersae des Ruhrkarbons, ihre Morphographie und Stratigraphie mit Ausblicken auf Arten anderer Gebiete und Zeitabschnitte. Teil I. - Palaeontographica, Bd. 98 Abt. B, pp. 1-136. - Stuttgart.

PurI, H. S., 1966. Ecologic distribution of recent Ostracoda. - Proc. of Symposium on Crustacea. Part 1, Marine Biological Association of India, Mandapam Camp.

Reinhardt, P., 1963. Megasporen aus dem Keuper Thüringens. - Freiberger Forsch.-H., C 164, pp. 115-128. - Freiberg.

Reyment, R. A., 1960. Studies on Nigerian Upper Cretaceous and Lower Tertiary Ostracoda. Part 1: Senonian and Maestrichtian Ostracoda. - Stockh. Contr. Geol., vol. VII, pp. 1-238. - Stockholm.

SARS, G. O., 1866. Oversigt af Norges marine Ostracoder. - Vidensk. Selsk. i Christiania, Forh. - Christiania (Oslo).

Sorgenfrei, Th. \& Buch, A., 1964. Deep Tests in Denmark 1935-1959. - Danmarks Geologiske Undersøgelse, III. Række, No. 36. - København.

Stoermer, N. \& Wienholz, E., 1967. Mikrobiostratigraphie an der Lias/Dogger-Grenze in Bohrungen nördlich der Mitteldeutschen Hauptscholle. - Jb. Geol., Bd. 1, pp. $533-$ 592. - Berlin.

Sylvester-Bradley, P. C., 1948. Bathonian ostracods from the Boueti bed of Langton Herring, Dorset. Geol. Mag., vol. 85, No. 4. - London.

URLICHS, M., 1966. Zur Fossilführung und Genese des Feuerlettens, der Rät-Lias-Grenzschichten und des unteren Lias bei Nürnberg. - Erlanger geol. Abh., H. 64. - Erlangen.

Usbeck, J., 1952. Zur Kenntnis von Mikrofauna und Stratigraphie im unteren Lias alpha Schwabens. - Neues Jb. Geol. u. Paläont., Abh., 95, 3, pp. 371-476. - Stuttgart.

VANGEROW, E. F., 1954. Megasporen und andere pflanzliche Mikrofossilien aus der Aachener Kreide. - Palaeontographica, Bd. 96 Abt. B, pp. 24-38. - Stuttgart.

Wicher, C. A., 1938. Mikrofaunen aus Jura und Kreide insbesondere Nordwestdeutschlands. 1. Teil: Lias $\alpha-\varepsilon$. - Preuss. Geol. Landesanstalt, N. Folge, H. 193. - Berlin.

- 1942. Praktikum der angewandten Mikropaläontologie. - Berlin-Zehlendorf.

- 1951. Zur mikropaläontologischer Gliederung des nichtmarinen Rät. - Erdöl und Kohle, 4. Jahrg., H. 12, pp. 755-760. - Hamburg.

- 1957. Die mikropaläontologische Gliederung des nichtmarinen Keuper. - Erdöl und Kohle, 10. Jahrg., H. 1, pp. 3-7. - Hamburg.

WILL, H-J., 1969. Untersuchungen zur Stratigraphie und Genese des Oberkeupers in Nordwestdeutschland. - Beih. Geol. Jb., H. 54. - Hannover.

Zerndt, J., 1938. Die Eignung von Megasporen als Leitfossilien. - II. Congr. Stratigr. Carbonif., C.R., tom. III, pp. 1711-1732. - Maestricht. 
PLATES 
Plate I

D.G.U. Text

Catalogue No. page

Fig. 1. Calamospora rhaetica (JUNG) Рот.

1969-FB-1

19

Sample $\mathrm{M}_{67}$; Slide $\mathrm{M}_{67-\mathrm{x}}, 8.7 / 122.0$.

Max. diameter : $216 \mu$

Transmitted light, $\times 210$.

Fig. 2. Calamospora rhaetica (JUNG) Pot.

1969-FB-2

Sample $\mathrm{M}_{70}$; Slide $\mathrm{M}_{70-\mathrm{x}}, 5.7 / 122.2$.

Max. diameter: $218 \mu$.

Transmitted light, $\times 210$.

Figs. 3-4. Trileites pinguis (HARris) POT................... 1969-FB-3

Sample $\mathrm{M}_{62}$; $\mathrm{SH}-2-\mathrm{FB}$.

Equatorial diameter: $390 \mu$.

Fig. 3: Proximal view, $\times 100$.

Fig. 4: Prox. surface of the exine, $\times 1000$.

Figs. 5-6. Trileites cf. pedinacron (HARRIS) POT.

1969-FB-4

19

Sample $\mathrm{M}_{62}$; $\mathrm{SH}-1-\mathrm{FB}$.

Equatorial diameter: $305 \mu$.

Fig. 5: Proximal view, $\times 150$.

Fig. 6: Prox. surface of the exine near apex, $\times 5250$.

Phot. A. Nørgaard Jensen (figs. 3-6) and the author (figs. 1-2).

Notes to pl. I - X: All the photos taken by A. NørgaArd Jensen are scanning electronic micrographs. In a few of the figures the background is retouched. The specimens are shown in several different magnifications, as it was desired to utilize the negatives to their full extent. 

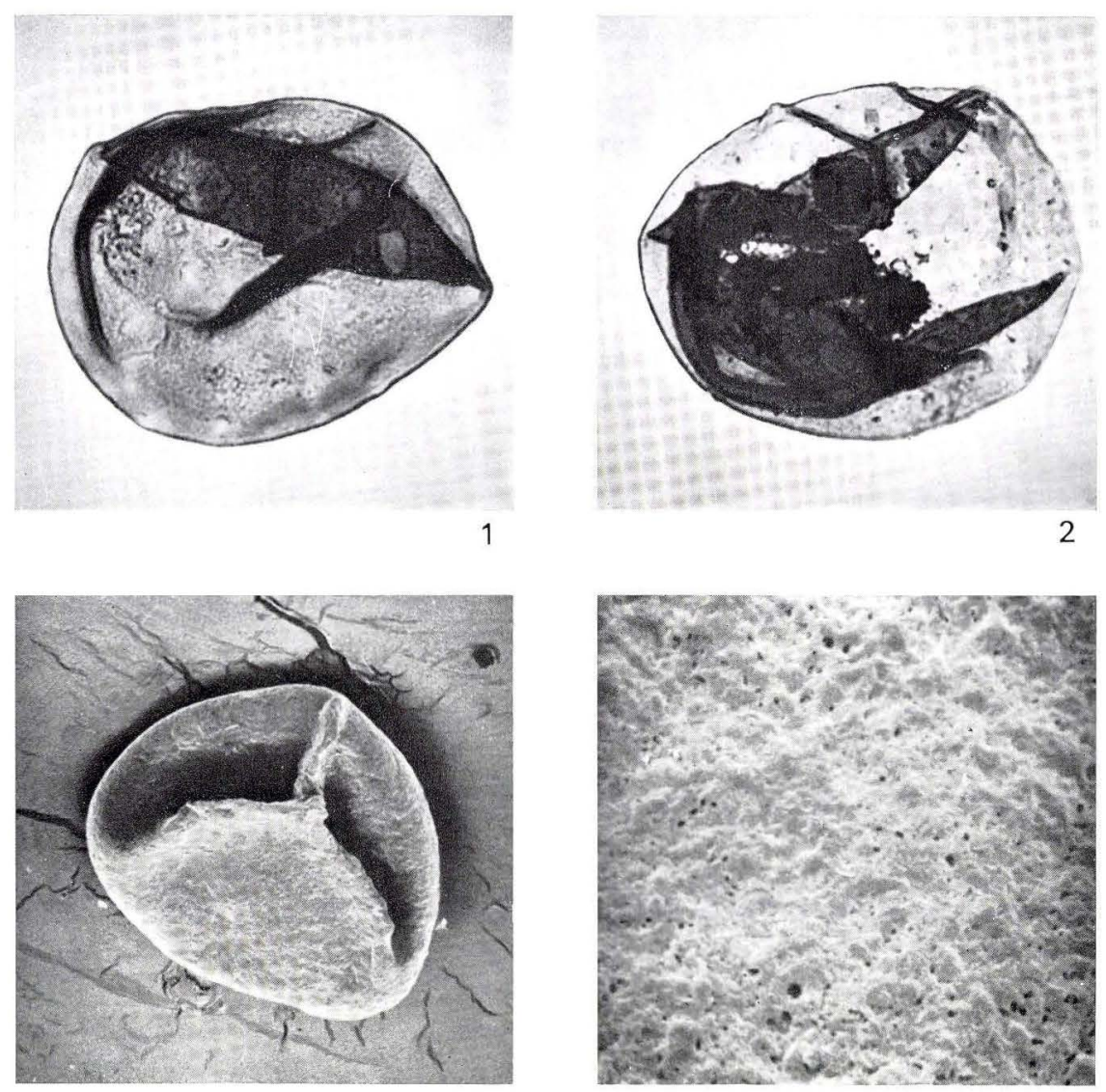

3
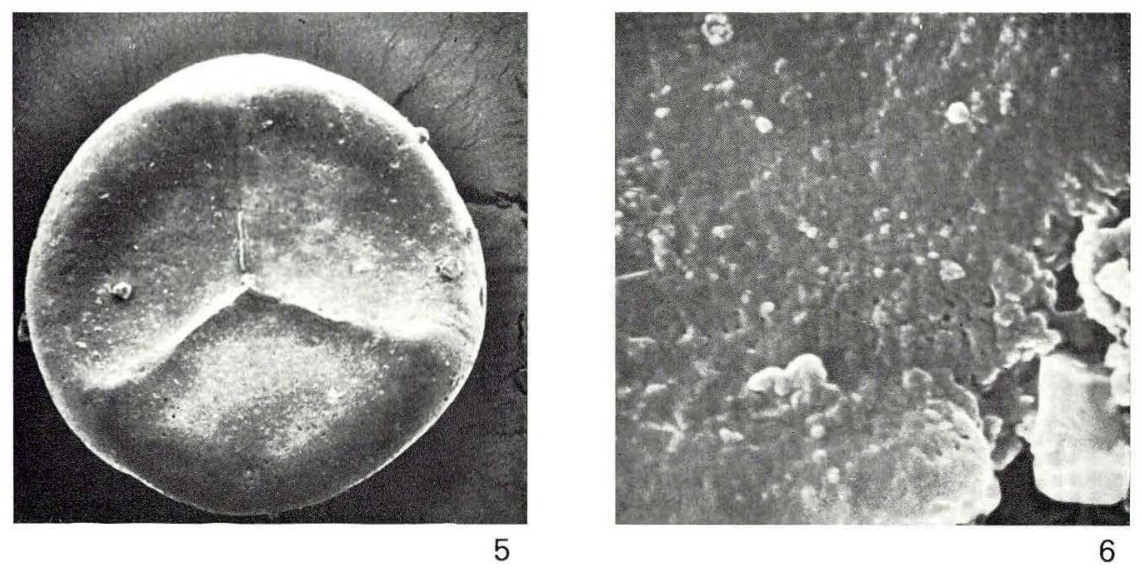


\section{Plate II}

D.G.U. Text

Catalogue No. page

Figs. 1-2. Trileites cf. pedinacron (HARRIS) Po

Fig. 1: Equatorial view, $\times 150$.

Fig. 2: Proximal pole, $\times 790$.

Fig. 3. Trileites $\mathrm{cf}$. pedinacron (HARRIS) Рот............. 1969-FB-5

Sample $\mathrm{M}_{53}$; Slide $\mathrm{M}_{53-\mathrm{x}-1}, 9.6 / 122.7$.

Vertical thin section of the exine,

equatorial part, $\times 1150$.

Transmitted light, oil imm.

Figs. 4-5. Trileites cf. pedinacron (HARris) PoT............. 1969-FB-6

Sample $\mathrm{M}_{61}$; SH-1-FB.

Equatorial diameter: $660 \mu$.

Fig. 4: proximal view, $\times 70$.

Fig. 5: Corroded proximal surface of the exine, $\times 1400$.

Phot. A. Nørgaard Jensen (figs. 1, 2, 4, 5) and the author (fig. 3). 
D.G.U. II. Rk. Nr. 94

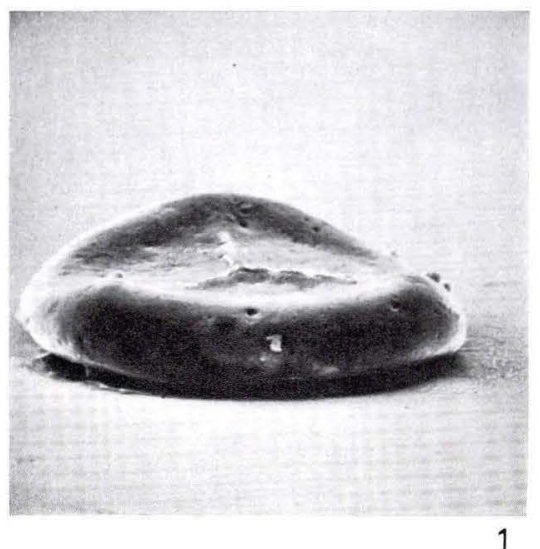

1
Plate II

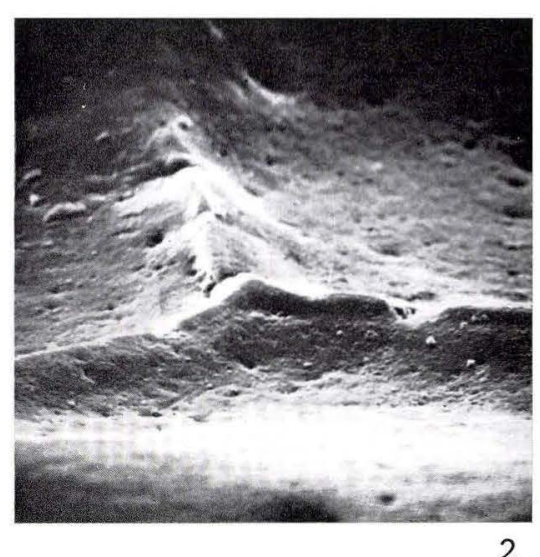

2

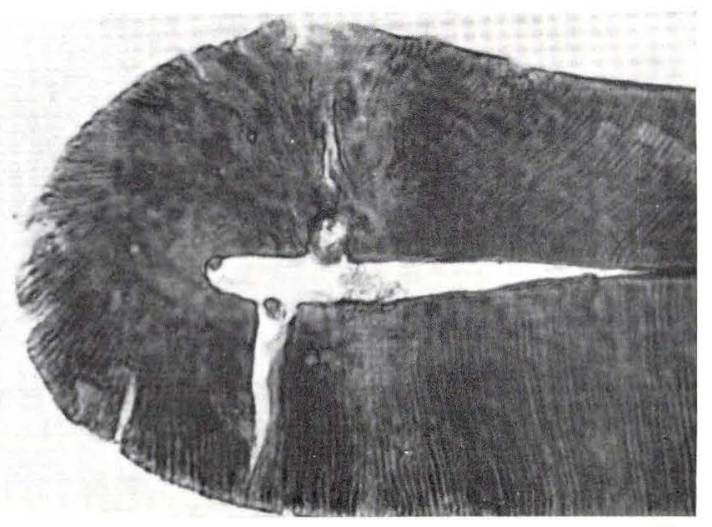

3
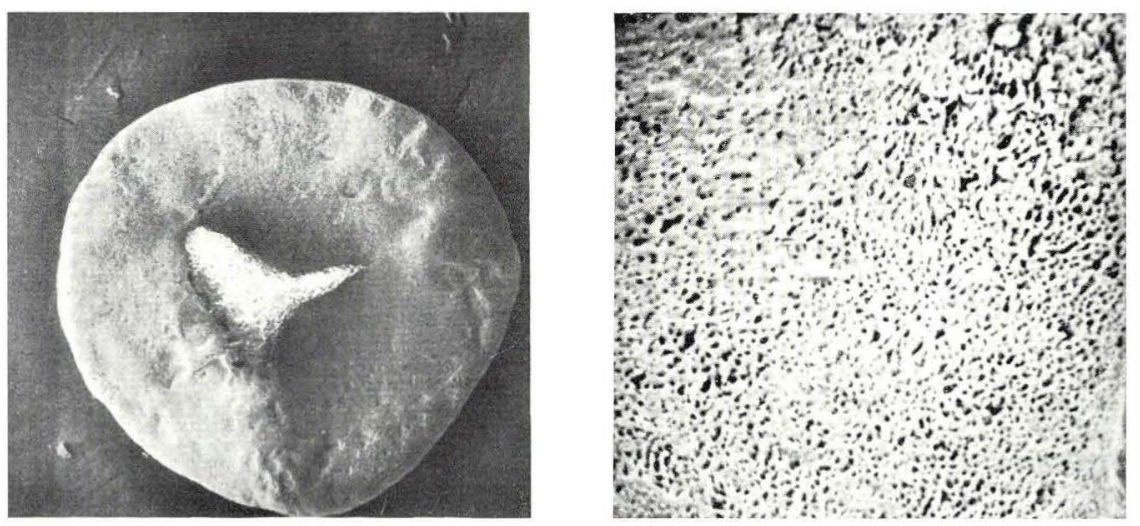

4 
Plate III

D.G.U. Text

Catalogue No. page

Figs. 1-2. Verrutriletes utilis (MARCINKIEwICZ) MARC.......... 1969-FB-7 23 Sample $\mathrm{M}_{70}$; SH-1-FB.

Equatorial diameter: $470 \mu$.

Fig. 1: Proximal view, $\times 95$.

Fig. 2: Surface of contact area, $\times 960$.

Figs. 3-4. Verrutriletes utilis (MARCINKIEwICZ) MARC.......... 1969-FB-8 23 Sample $\mathrm{M}_{62}$; SH-2-FB.

Equatorial diameter: $395 \mu$.

Fig. 3: Proximal view, $\times 110$.

Fig. 4: Surface of contact area, $\times 1100$.

Figs. 5-6. Verrutriletes utilis (MARCINKIEWICZ) MARC.

1969-FB-9

Sample $\mathrm{M}_{62}$; $\mathrm{SH}-1-\mathrm{FB}$.

Equatorial diameter: $510 \mu$.

Fig. 5: Proximal view, $\times 75$.

Fig. 6: Surface of contact area, $\times 360$.

Phot. A. Nørgaard Jensen. 


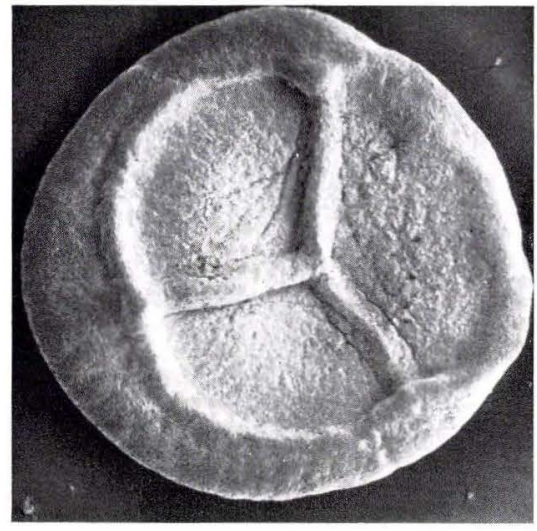

1

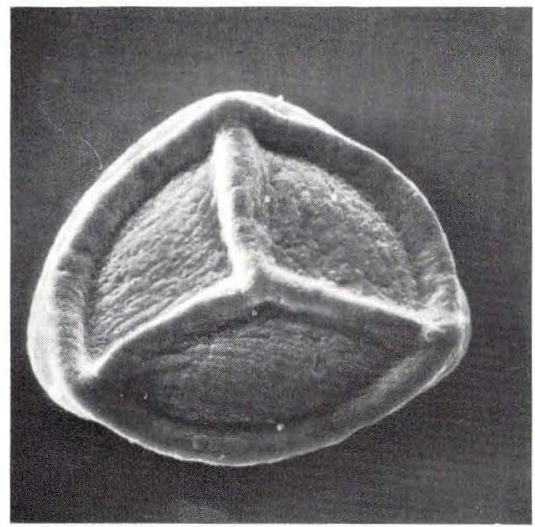

3

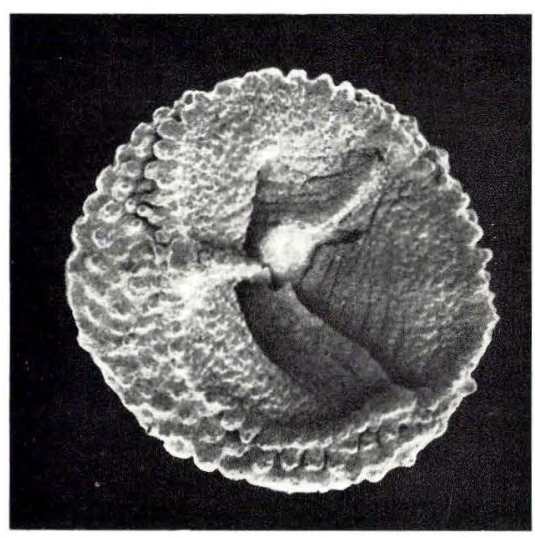

5

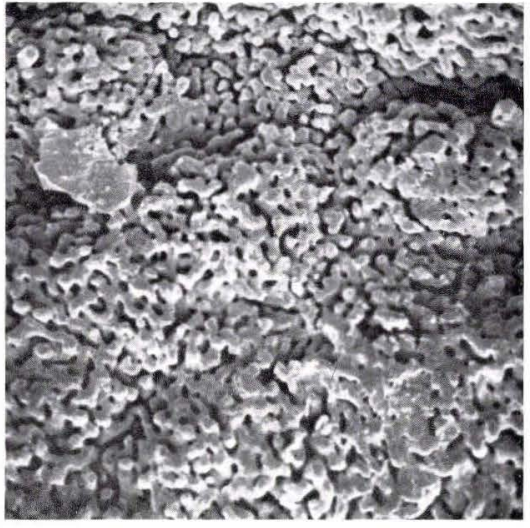

2

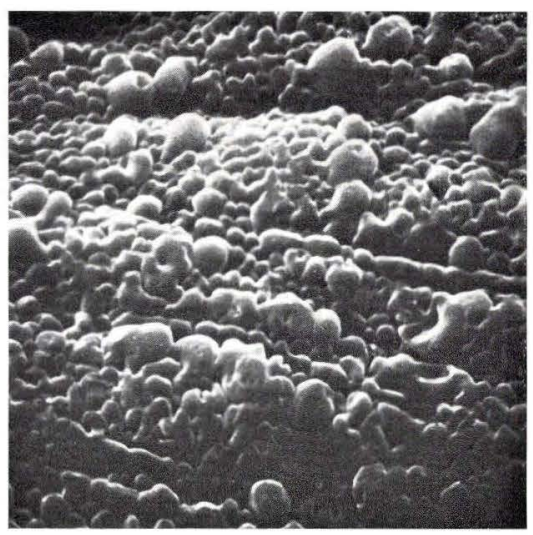

4

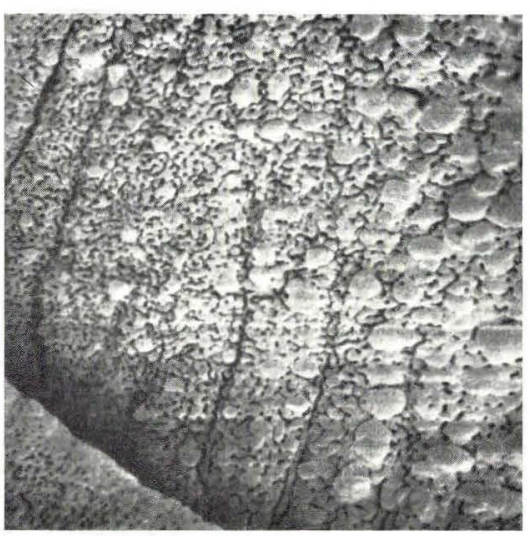




\section{Plate IV}

D.G.U. Text

Catalogue No. page

Fig. 1. Verrutriletes utilis (MARCINKIEWICZ) MARC......... 1969-FB-9 23

Equatorial exine sculpture, $\times 360$.

Figs. 2-3. Verrutriletes utilis (Marcinkiewicz) Marc.......... 1969-FB-10 23

Sample $\mathrm{M}_{62}$; SH-2-FB.

Equatorial diameter: $320 \mu$.

Fig. 2: Proximal view, $\times 140$.

Fig. 3: Exine sculpture around the apex, $\times 1450$.

Fig. 4. Verrutriletes franconicus JUNG.

1969-FB-11

Sample $\mathrm{M}_{6}$; Slide $\mathrm{M}_{6-\mathrm{x}}, 6.7 / 128.7$.

Equatorial diameter: $500 \mu$.

Proximal view, $\times 100$.

Transmitted light.

Figs. 5-6. Verrutriletes franconicus JUNG.

1969-FB-12

Sample $\mathrm{M}_{4}$; SH-1-FB.

Equatorial diameter: $575 \mu$.

Fig. 5: Proximal view, $\times 75$.

Fig. 6: Exine sculpture around the prox. pole, $\times 150$.

Phot. A. Nørgaard Jensen (figs. 1, 2, 3, 5, 6) and the author (fig. 4). 

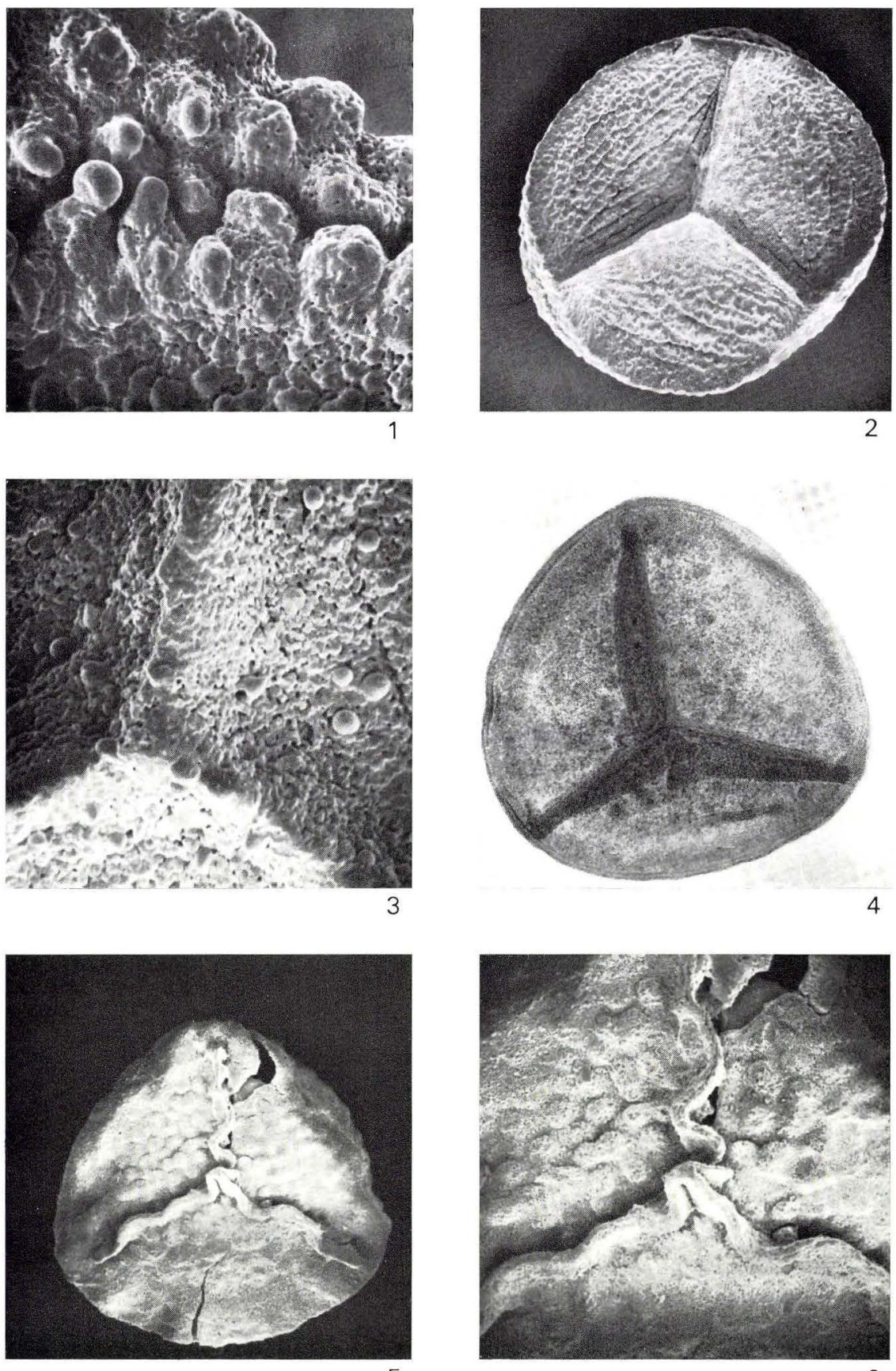
Plate V

D.G.U. Text

Catalogue No. page

Figs. 1-2. Maexisporites cf. misellus MARCINkIEwrCz.......... 1969-FB-13 22 Sample $\mathrm{M}_{69}$; $\mathrm{SH}-1-\mathrm{FB}$.

Equatorial diameter: $280 \mu$.

Fig. 1: Proximal view, $\times 150$.

Fig. 2: Detail of exine sculpture, $\times 740$.

Figs. 3-4-5. Bacutriletes tylotus (HARRIS) POT.

1969-FB-14

Sample $\mathrm{M}_{62}$; $\mathrm{SH}-1-\mathrm{FB}$.

Max. equatorial diameter: $520 \mu$.

Fig. 3: Proximal view, $\times 80$.

Fig. 4: Exine sculpture near the apex, $\times 410$.

Fig. 5: Exine sculpture near the equator, $\times 410$.

Fig. 6. Bacutriletes reticuliferus n. sp.............. 1969-FB-15 24 Sample $\mathrm{M}_{71}$; slide $\mathrm{M}_{71-\mathrm{x}}, 15.4 / 124.4$.

Equatorial diameter: $290 \mu$.

Holotypus, proximal view, $\times 150$.

Transmitted light.

Phot. A. Nørgaard Jensen (figs. 1-5) and the author (fig. 6). 


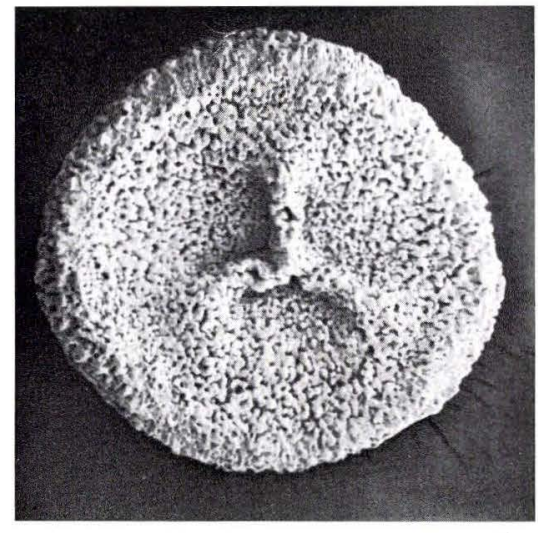

1

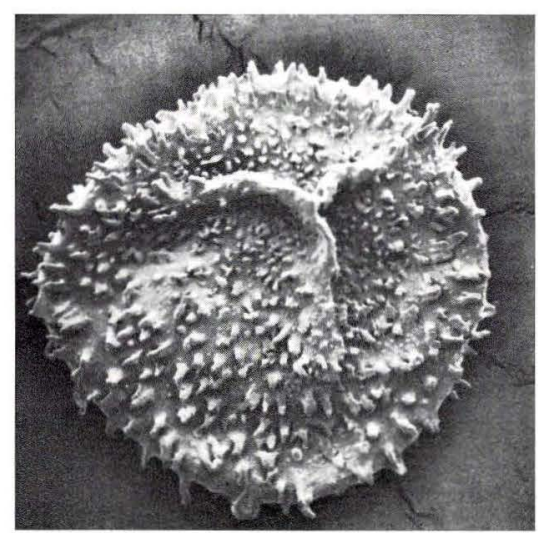

3

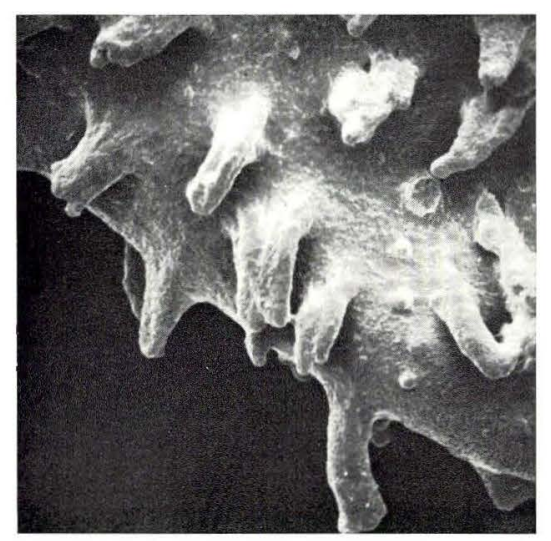

5

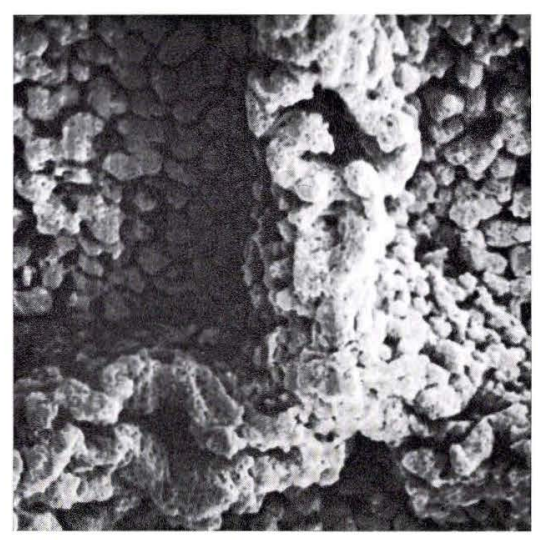

2

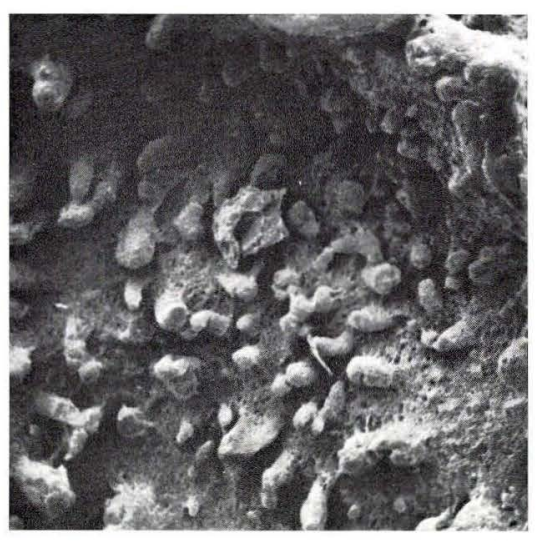

4

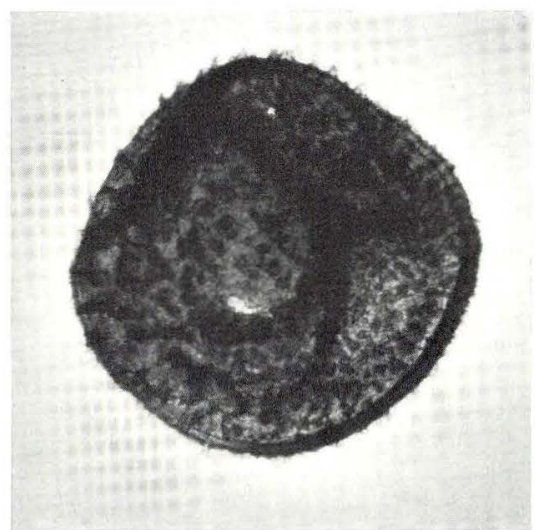




\section{Plate VI}

D.G.U. Text Catalogue No. page

Figs. 1-2. Bacutriletes reticuliferus n. sp.

Sample $\mathrm{M}_{71}$; $\mathrm{SH}-2-\mathrm{FB}$.

Diameter : $230 \mu$.

Fig. 1: Equatorial view, $\times 160$.

Fig. 2: Distal exine sculpture, $\times 1000$.

Figs. 3-4. Bacutriletes reticuliferus n. sp.

Sample $\mathrm{M}_{71}$; $\mathrm{SH}-3-\mathrm{FB}$.

Diameter: $320 \mu$

Fig. 3: Specimen with partly destroyed sculpture, $\times 160$.

Fig. 4: Proximal exine sculpture, $\times 1000$.

Figs. 5-6. Horstisporites areolatus (HARRIS) POT.

Sample $\mathrm{M}_{4}, \mathrm{SH}-1-\mathrm{FB}$.

Equatorial diameter: $750 \mu$.

Fig. 5: Proximal view, $\times 55$.

Fig. 6: Proximal exine sculpture, $\times 240$.

Phot. A. Nørgaard Jensen. 

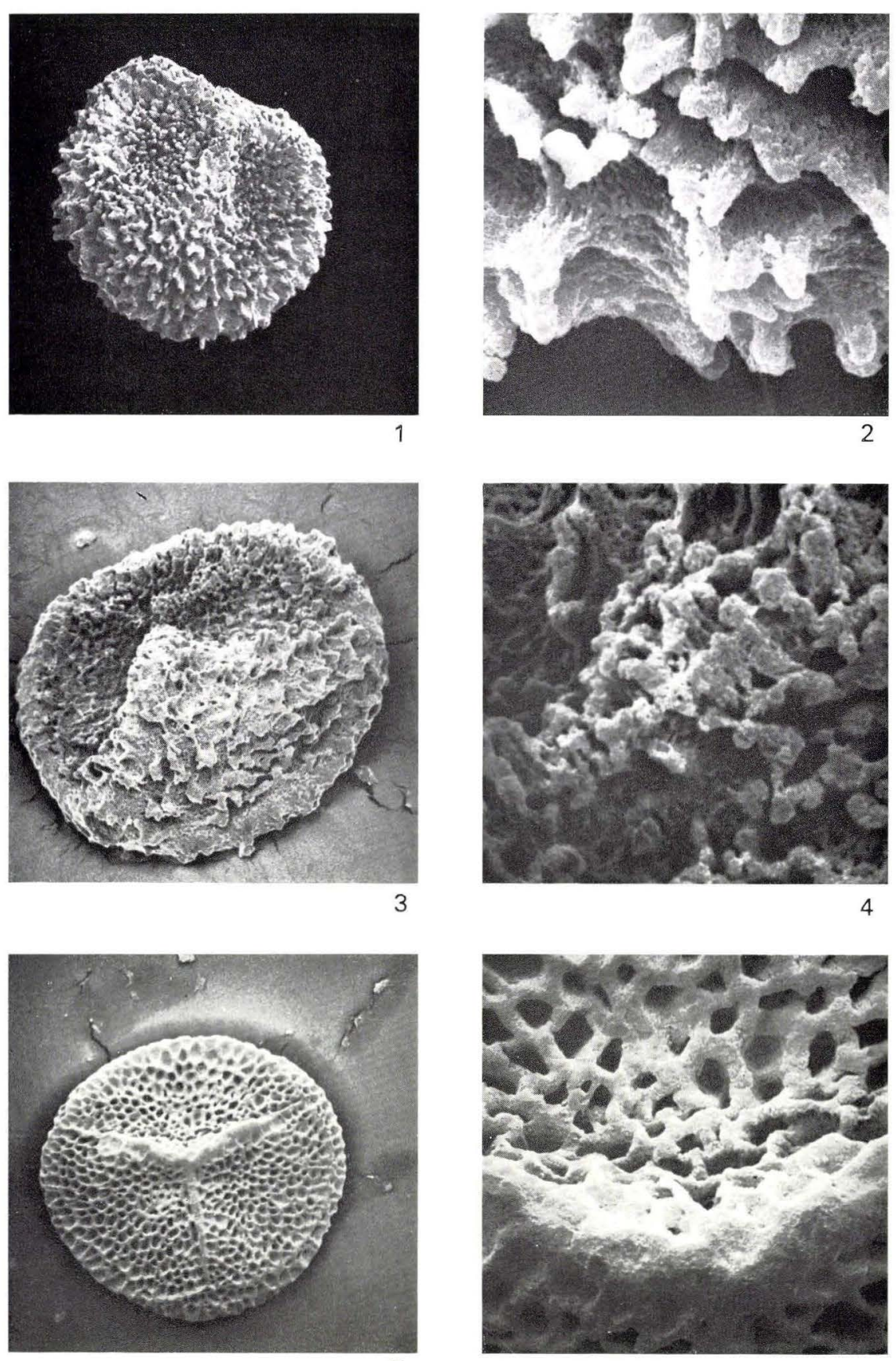
Figs. 1-2. Horstisporites rexargenteus (HARRIS) POT Sample $\mathrm{M}_{68}$; SH-1-FB.

Fig. 1: Proximal view, $\times 120$.

Fig. 2: Detail of exine sculpture, $\times 400$.

Figs. 3-4. Horstisporites harrisi (MURRAY) PoT.

Sample $\mathrm{M}_{4}$; SH-1-FB.

Equatorial diameter: $480 \mu$.

Fig. 3: Proximal view, $\times 90$.

Fig. 4: Exine sculpture, $\times 165$.

Figs. 5-6. Horstisporites sp. (Type No. 5) Sample $\mathrm{M}_{103}$; $\mathrm{SH}-2-\mathrm{FB}$.

Equatorial diameter: $445 \mu$.

Fig. 5: Equatorial view, $\times 75$.

Fig. 6: Detail of the distal reticulum, $\times 640$.

Phot. A. Nørgaard Jensen. 

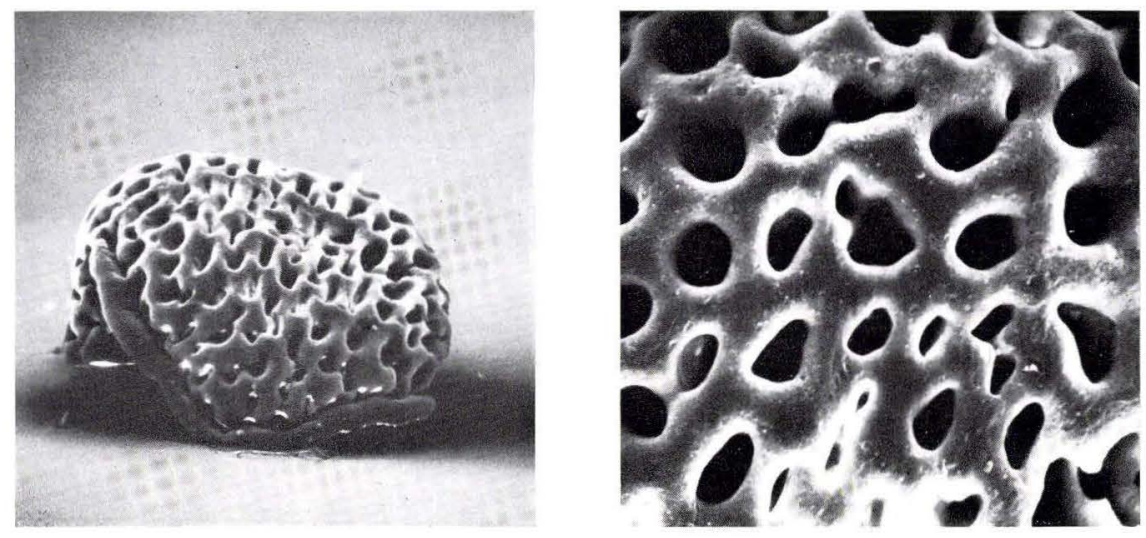

1

2
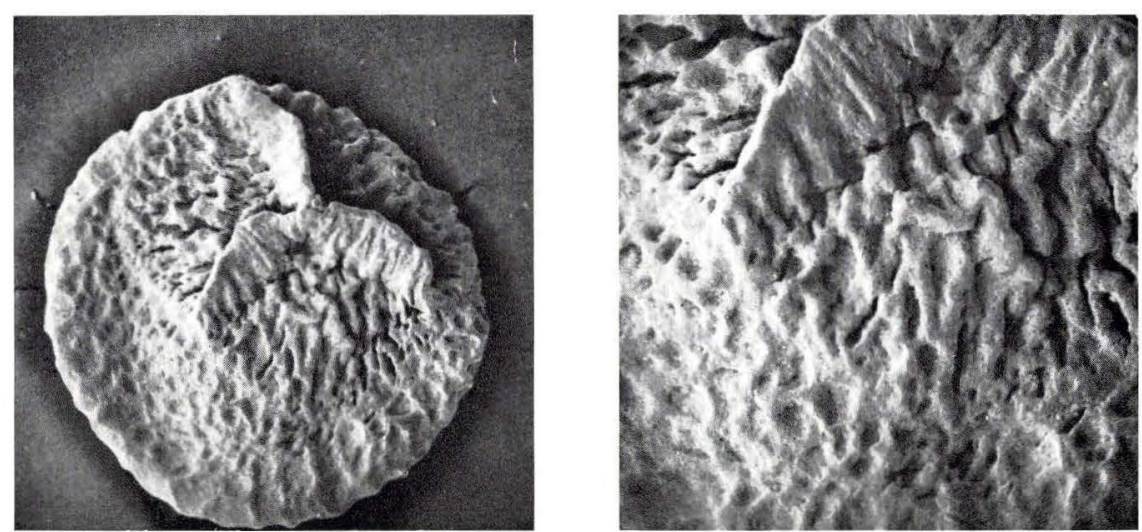

3

4
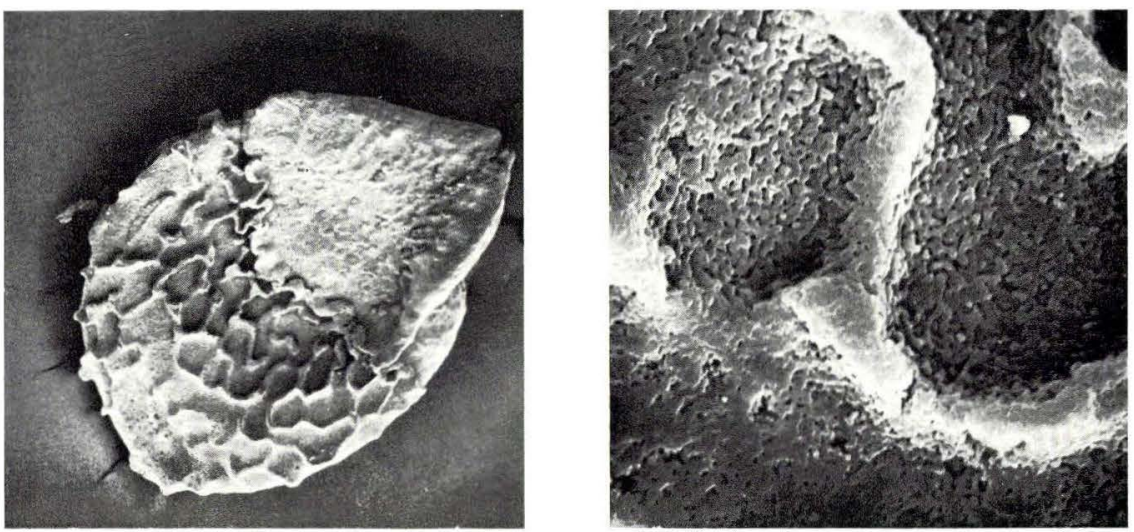


\section{Plate VIII}

D.G.U. Text

Catalogue No, page

Figs. 1-2. Nathorstisporites hopliticus JUNG.

1969-FB-22 30

Sample $\mathrm{M}_{4}$. SH-1-FB.

Equatorial diameter: $460 \mu$.

Fig. 1: Equatorial view, $\times 90$.

Fig. 2: Detail of fig. 1, distal sculpture, $\times 400$.

Figs. 3-4-6. Nathorstisporites hopliticus JUNG. .

Sample $\mathrm{M}_{25}$. SH-1-FB.

Equatorial diameter: $510 \mu$.

Fig. 3: Equatorial view, $\times 70$.

Fig. 4: Equatorial sculpture, $\times 340$.

Fig. 6: Structure of the capilli, $\times 1350$.

Fig. 5. Nathorstisporites hopliticus JuNC

Sample $\mathrm{M}_{4}$. Slide $\mathrm{M}_{4-\mathrm{x}-3}, 11.8 / 122.5$.

Equatorial diameter: $416 \mu$.

Equatorial view, $\times 90$.

Transmitted light.

Phot. A. Nørgaard Jensen (figs. 1, 2, 3, 4, 6) and the author (fig. 5). 

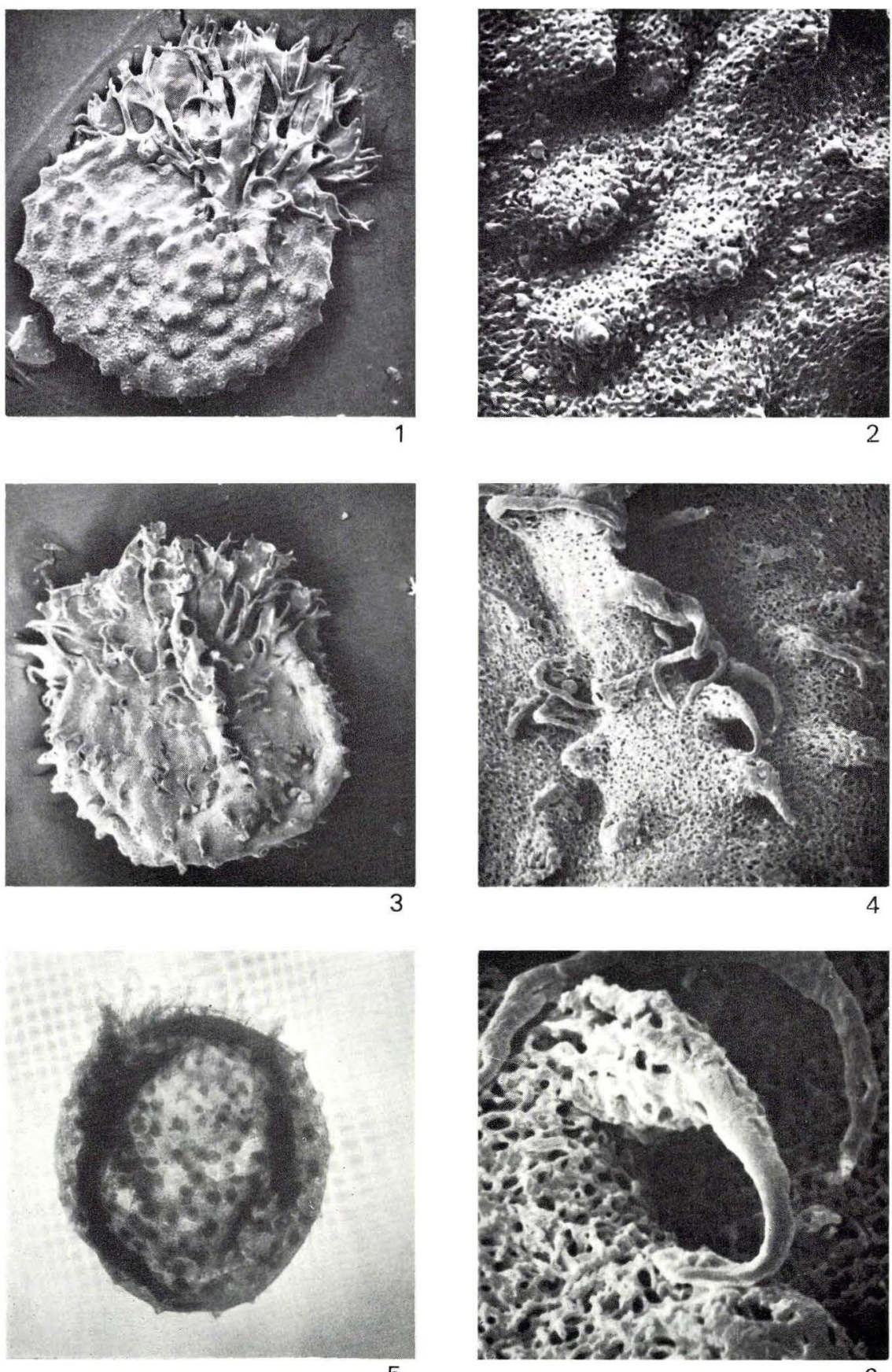


\section{Plate IX}

D.G.U. Text

Catalogue No. page

Figs. 1-2. Minerisporites ales (HARRIS) РОT.

1969-FB-25 32

Sample $\mathrm{M}_{62}$; $\mathrm{SH}-2-\mathrm{FB}$.

Diameter of central body: appr. $260 \mu$.

Fig. 1: Equatorial view, $\times 95$.

Fig. 2: Distal sculpture, $\times 240$.

Fig. 3. Minerisporites ales (HARRIS) POT.

1969-FB-26

Sample $\mathrm{M}_{95}$; $\mathrm{SH}-2-\mathrm{FB}$.

Diameter of central body: appr. $190 \mu$.

Equatorial view, $\times 160$.

Fig. 4. Minerisporites ales (HARRIS) POT.

1969-FB-27

Sample $\mathrm{M}_{95}$; $\mathrm{SH}-2-\mathrm{FB}$.

Diameter of central body: appr. $200 \mu$.

Proximal view, $\times 140$.

Figs. 5-6. Minerisporites ales (HARRIS) Рот.

Sample $\mathrm{M}_{95}$; $\mathrm{SH}-2-\mathrm{FB}$.

Diameter of central body: appr. $190 \mu$.

Fig. 5: Equatorial view, $\times 140$.

Fig. 6: Distal sculpture, $\times 350$.

Phot. A. NørgaArd Jensen. 

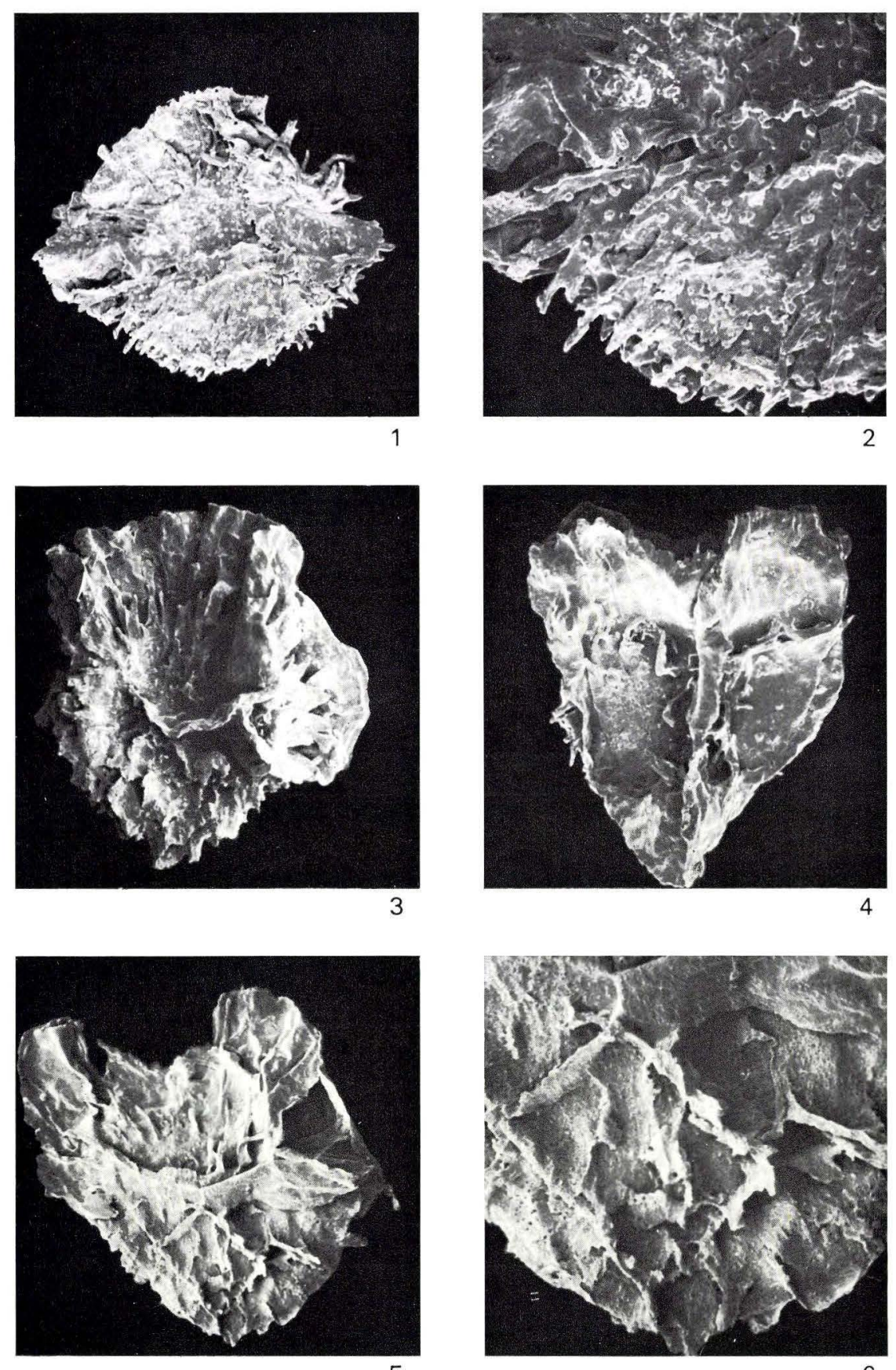


\section{Plate X}

D.G.U. Text

Catalogue No. page

Fig. 1. Minerisporites ales (Harkis) Pot................ 1969-FB-29 32

Sapmle $\mathrm{M}_{95}$; slide $\mathrm{M}_{95-\mathrm{x}-1}, 9.1 / 124.3$.

Equatorial diameter of central body: $230 \mu$.

Equatorial view, $\times 145$.

Transmitted light.

Fig. 2. Minerisporites ales (HARris) POT

1969-FB-30

Sample $\mathrm{M}_{95}$; slide $\mathrm{M}_{95-\mathrm{x}-2}, 9.5 / 120.0$.

Equatorial diameter of central body: $290 \mu$.

Proximal view, $\times 125$.

Transmitted light.

Fig. 3. Macrosporites cf. brasserti (Stach \& Zerndt) Pot. ... 1969-FB-31 31

Samlle $\mathrm{M}_{4}$; slide 1969-FB-31.

Equatorial diameter: $900 \mu$.

Proximal view, $\times 55$.

Reflected light.

Fig. 4. Lepidopteris ottonis (GoEPP.) SCHIMPER

1969-FB-32

Sample $\mathrm{M}_{87}$, slide $\mathrm{M}_{87-\mathrm{x}-1}, 10.6 / 122.7$.

Stomatal apparatus, $\times 1200$.

From cuticular preparation of the leaf fragment shown

in fig. 5 .

Transmitted light, oil imm.

Fig. 5. Lepidopteris ottonis (GoepP.) SCHIMPER.

Sample $\mathrm{M}_{87}$, slide $\mathrm{M}_{87-\mathrm{x}}$.

Leaf fragment, $\times 4$.

Transmitted light.

Phot. O. NeergaArd Rasmussen (figs.3-5) and the author (figs. 1-2). 
D.G.U. II. Rk. Nr. 94

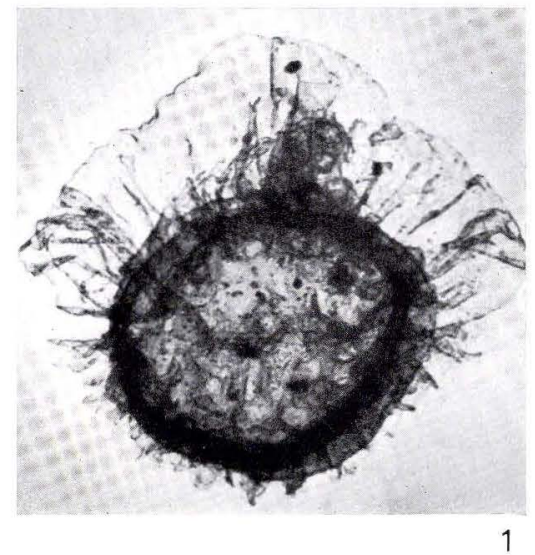

1

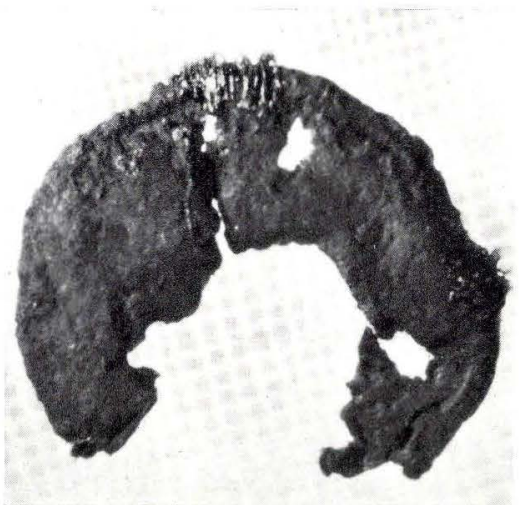

3
Plate X
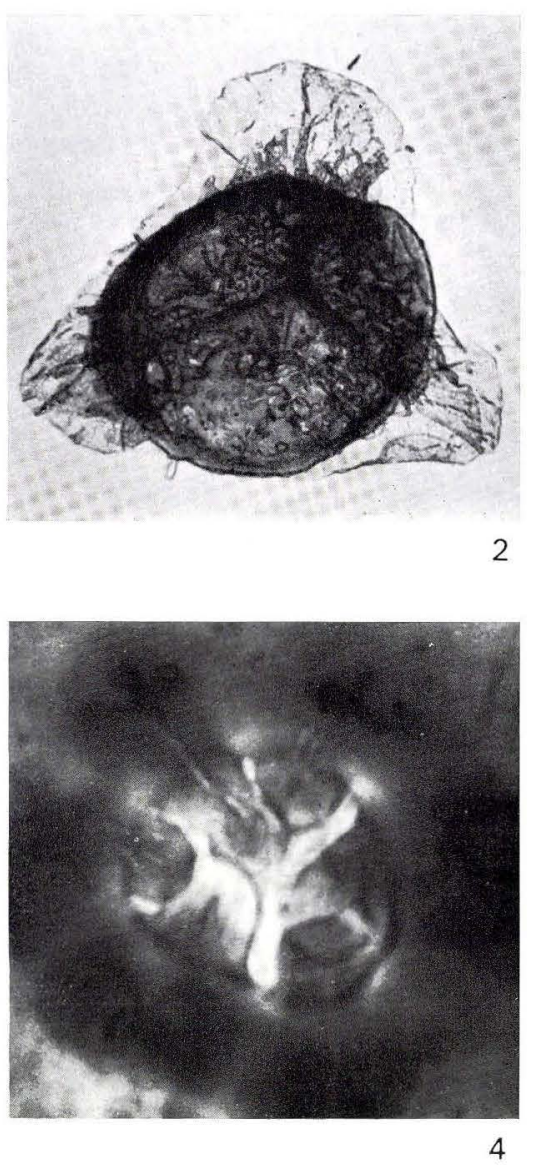

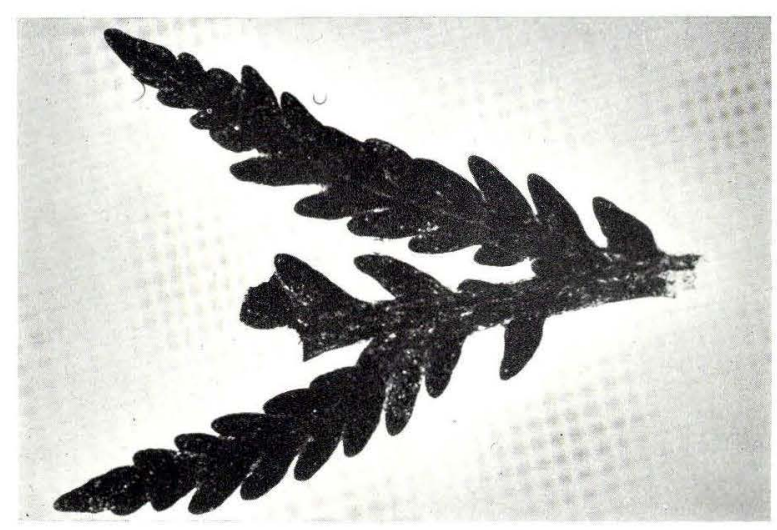




\section{Plate XI}

$60 \times$

D.G.U. Text

Catalogue No. page

Figs. 1a-d. Stenestroemia ? roedbyensis n. sp.

1969-OM-10

Right valve, + , holotype, sample $\mathrm{M}_{21}$.

Length: $0.53 \mathrm{~mm}$, height: $0.27 \mathrm{~mm}$.
$\mathrm{a}$, internal view.
b, external view.
c, posterior view.
d, ventral view.

Figs. 2a-c. Stenestroemia ? roedbyensis n. s

Carapace, , sample $\mathbf{M}_{21}$.

Length: $0.48 \mathrm{~mm}$, height: $0.24 \mathrm{~mm}$, breadth: $0.20 \mathrm{~mm}$.
a, lateral view.
b, posterior view.
c, ventral view.

Figs. 3a-c. Stenestroemia ? roedbyensis n. sp............. 1969-O M-9

Carapace, ô, sample $\mathrm{M}_{21}$.

Length: $0.54 \mathrm{~mm}$, height: $0.27 \mathrm{~mm}$, breadth: $0.22 \mathrm{~mm}$.
a, lateral view.
b, posterior view.
c, ventral view.

Phot. O. Neergaard Rasmussen. 


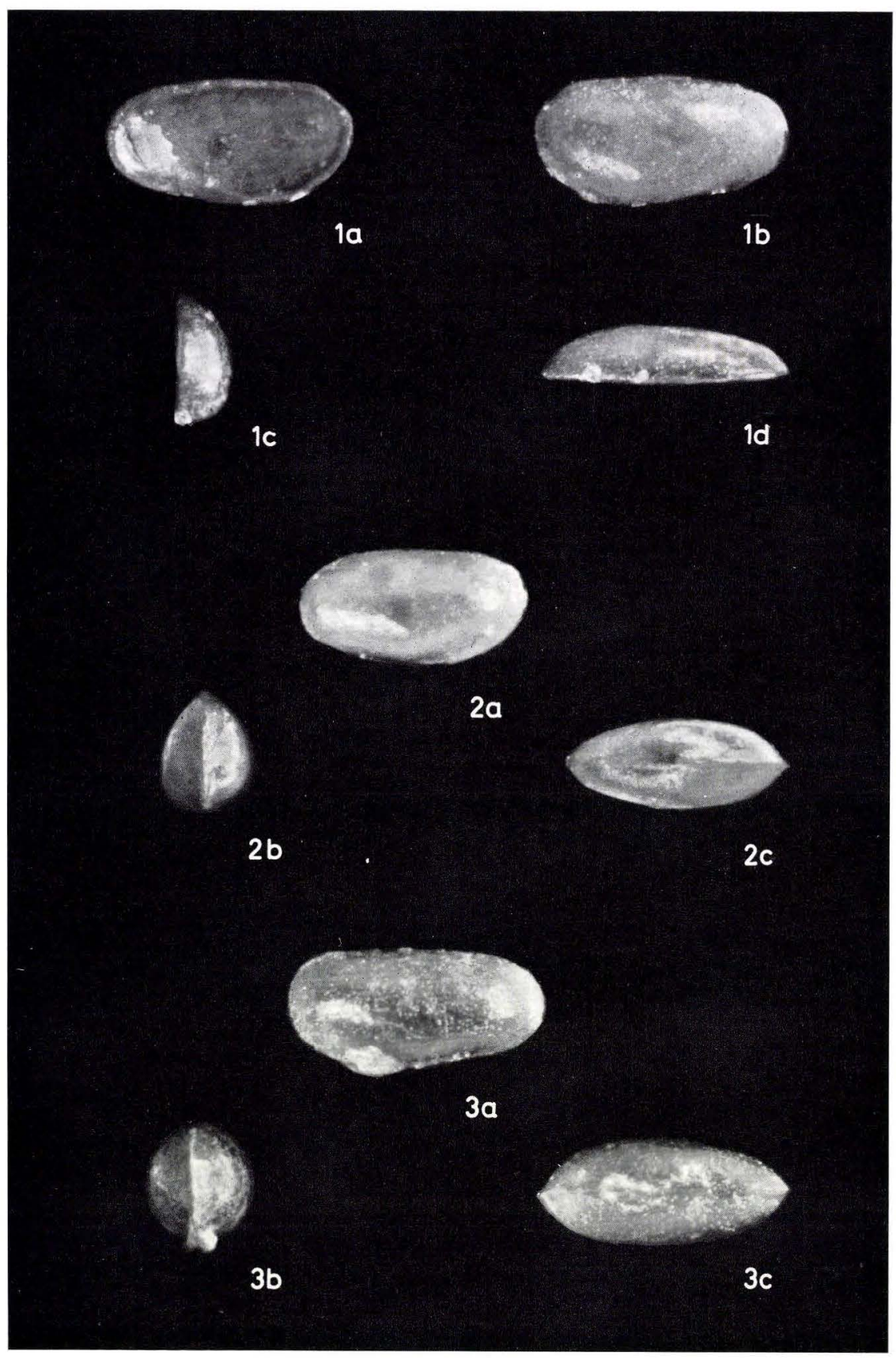


Plate XII

$60 \times$

D.G.U. Text

Catalogue No. page

Figs. 1a-b. Macrocypris No. 4023

1969-OM-4

Right valve, sample $\mathbf{M}_{21}$.

Length: $0.49 \mathrm{~mm}$, height: $0.25 \mathrm{~mm}$.

Lateral and dorsal view.

Figs. 2a-b. Paradoxostoma ? cf. P. ?fusiformis DreXler....... 1969-OM-5

Right valve ?, larva, sample $\mathrm{M}_{21}$.

Length: $0.30 \mathrm{~mm}$, height: $0.14 \mathrm{~mm}$.

Lateral and dorsal view.

Figs. 3a-b. Lophocythere elegans DREXLER.

1969-OM-1

Right valve, sample $\mathrm{M}_{8}$.

Length: $0.32 \mathrm{~mm}$, height $0.18 \mathrm{~mm}$.

Lateral and dorsal view.

Figs. 4a-b. Lophocythere sp. (4076).

Right valve, sample $\mathrm{M}_{8}$.

Length: $0.29 \mathrm{~mm}$, height: $0.16 \mathrm{~mm}$.

Lateral and dorsal view.

Figs. 5a-b. Lophocythere ? No. 4061

1969-OM-3

Right valve, sample $\mathrm{M}_{21}$.

Length: $0.29 \mathrm{~mm}$, height: $0.14 \mathrm{~mm}$.

Lateral and dorsal view.

Figs. 6a-b. Polycope No. 4065

1969-OM-21

Carapace, sample $\mathrm{M}_{20}$.

Length: $0.17 \mathrm{~mm}$, height: $0.17 \mathrm{~mm}$, breadth: $0.10 \mathrm{~mm}$.

a, left side.

b, anterior view.

Phot. O. NeergaArd Rasmussen. 


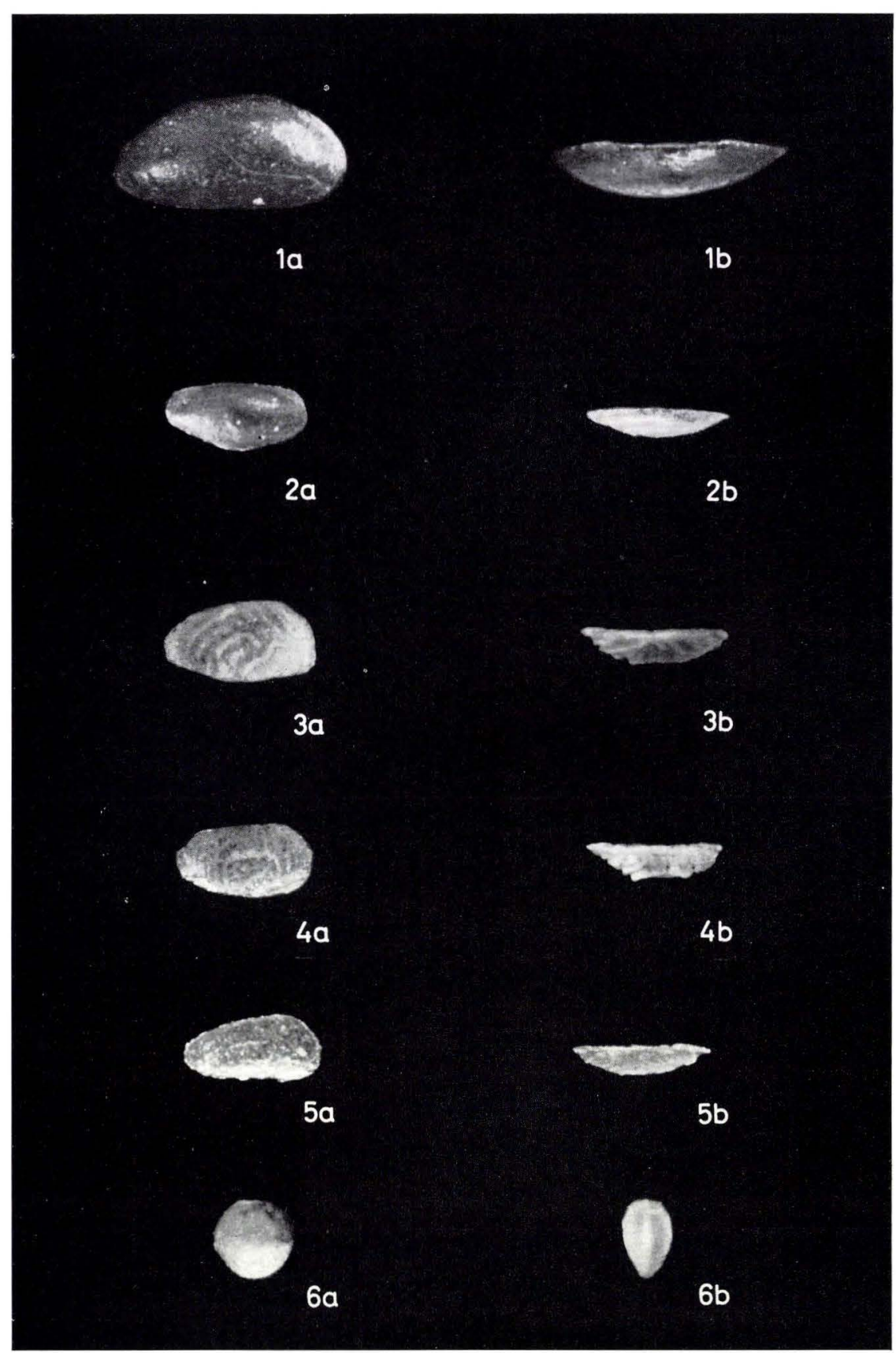




\section{Plate XIII}

$60 \times$

D.G.U. Text

Catalogue No. page

Figs. 1a-d. Procytheridea medioreticulata n. sp.

1969-OM-6

39

Right valve, holotype, sample $\mathrm{M}_{10}$.

Length: $0.56 \mathrm{~mm}$, height: $0.30 \mathrm{~mm}$.
a, internal view.
b, external view.
c, dorsal view.
d, ventral view.

Figs. 2a-c. Procytheridea medioreticulata n. s

1969-OM-7

Left valve, sample $\mathrm{M}_{10}$.

Length: $0.53 \mathrm{~mm}$, height: $0.31 \mathrm{~mm}$.
a, lateral view.
b, ventral view.
c, dorsal view.

Figs. 3a-c. Procytheridea sp. (4081).

Carapace, sample $\mathrm{M}_{18}$.

Length: $0.63 \mathrm{~mm}$, height: $0.33 \mathrm{~mm}$, breadth: $0.28 \mathrm{~mm}$.

a, right side.

b, dorsal view.

c, ventral view.

Phot. O. NeergaArd Rasmussen. 


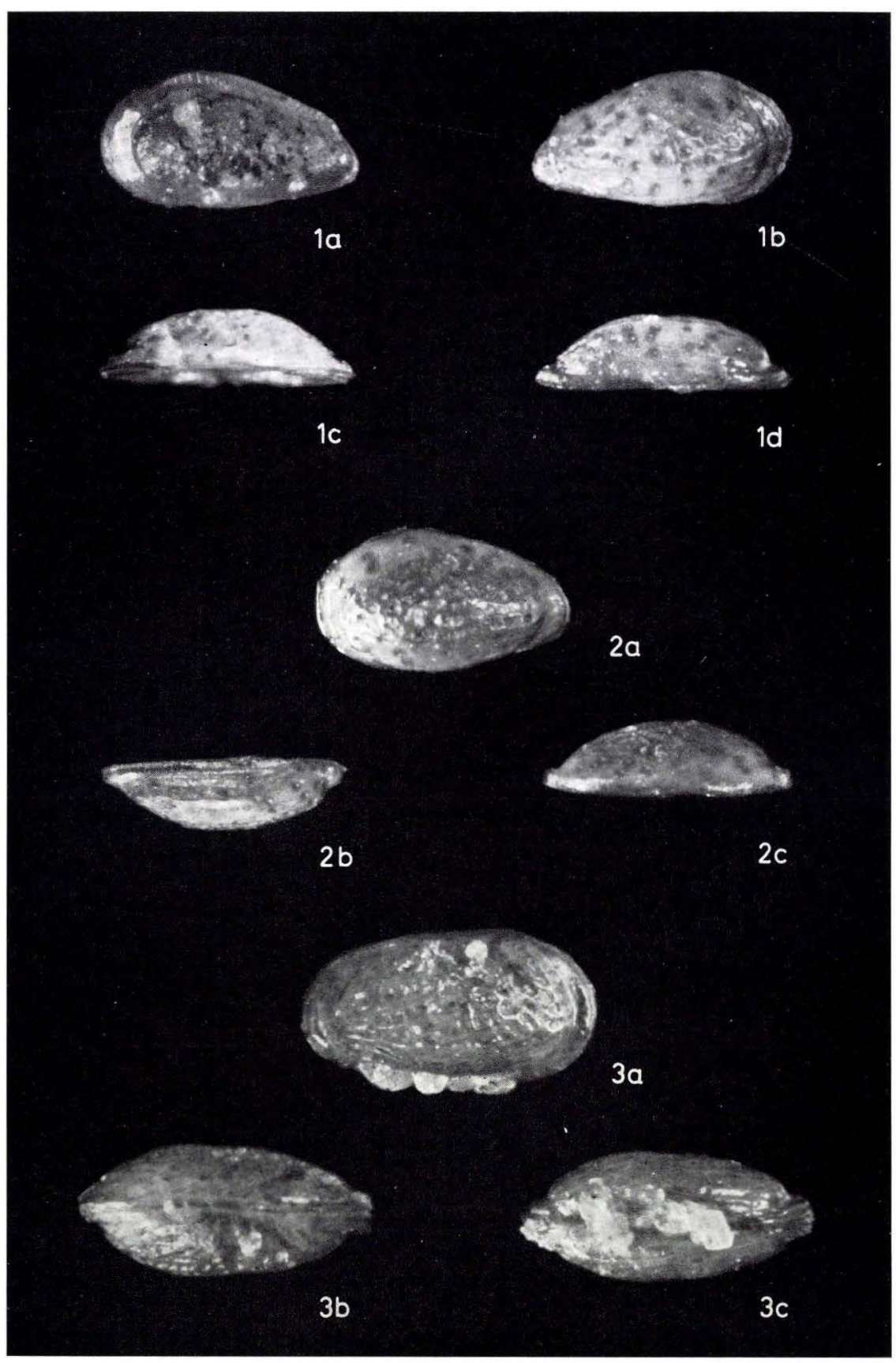




\section{Plate XIV}

$60 \times$

D.G.U. Text

Catalogue No. page

Figs. 1a-c. Ogmoconchella aspinata (DREXLER) . . . . . . . . . . 1969-OM-12 42

Carapace, ô, sample $\mathrm{M}_{21}$.

Length: $0.65 \mathrm{~mm}$, height: $0.44 \mathrm{~mm}$,

breadth: $0.33 \mathrm{~mm}$.

a, right side.

b, dorsal view.

c, posterior view.

Figs. 2a-c. Ogmoconchella aspinata (DREXLER).

Carapace, $q$, sample $\mathrm{M}_{21}$

Length: $0.59 \mathrm{~mm}$, height: $0.42 \mathrm{~mm}$, breadth: $0.32 \mathrm{~mm}$.
$a$, right side.
b, dorsal view.
c, posterior view.

Figs. 3a-c. Ogmoconchella aspinata (DREXLER).

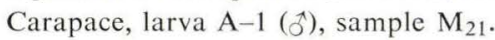

Length: $0.57 \mathrm{~mm}$, height : $0.39 \mathrm{~mm}$, breadth: $0.29 \mathrm{~mm}$.

a, right side.

b, dorsal view.

c, posterior view.

Phot. O. Neergaard Rasmussen. 


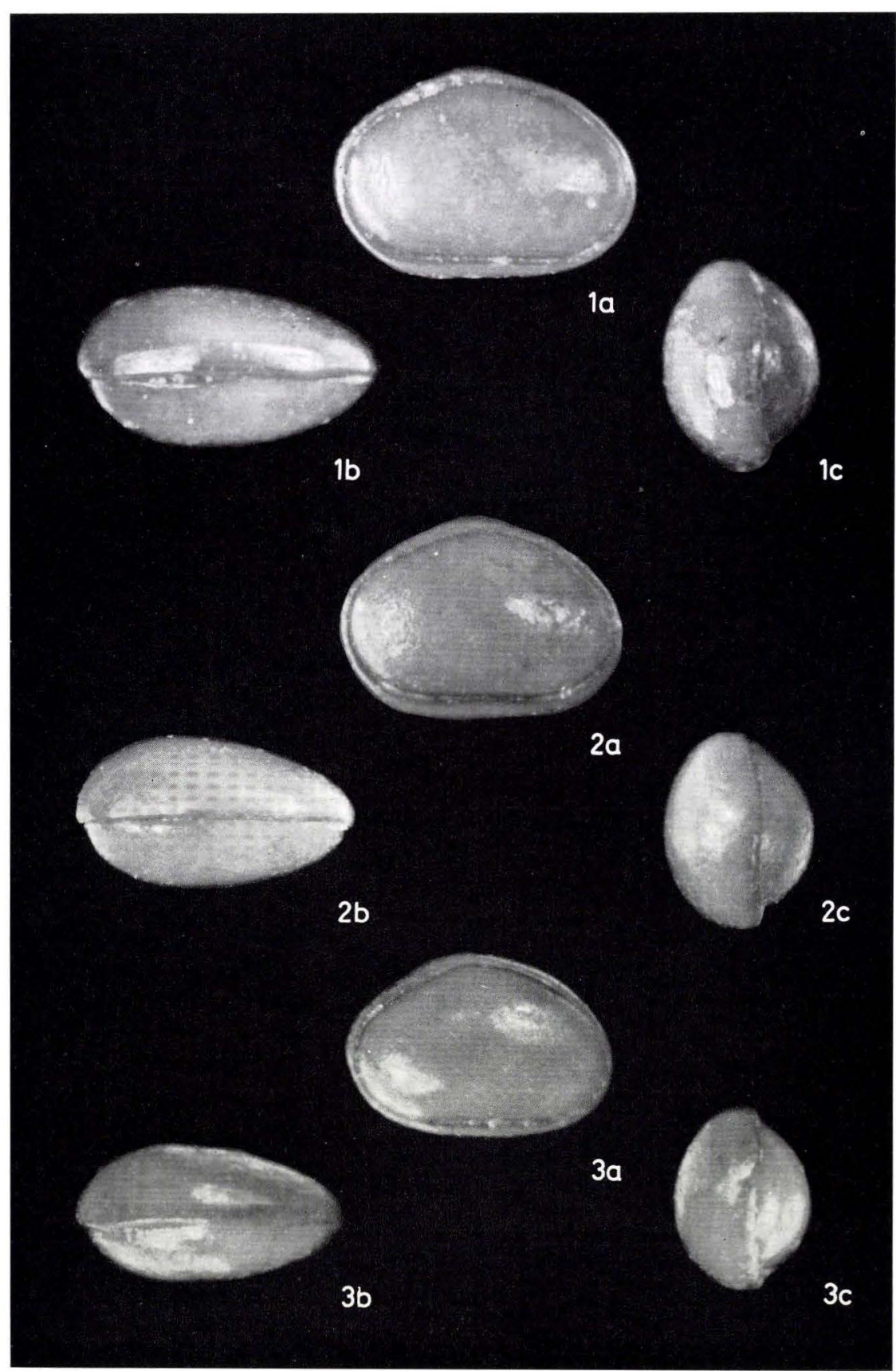




\section{Plate XV}

$60 \times$

D.G.U. Text

Catalogue No. page

Figs. 1a-c. Ogmoconchella aspinata (DREXLER)

1969-OM-13 42

Carapace, larva $\mathrm{A}-1$ (†), sample $\mathrm{M}_{21}$.

Length: $0.52 \mathrm{~mm}$, height : $0.34 \mathrm{~mm}$, breadth: $0.27 \mathrm{~mm}$.

a, right side.

b, dorsal view.

c, posterior view.

Fig. 2. Ogmoconchella aspinata (DREXLER).

1969-OM-15

Carapace, larva $\mathrm{A}-2$, right side,

sample $\mathbf{M}_{21}$. The posteroventral spine is broken.

Length: $0.44 \mathrm{~mm}$, height: $0.29 \mathrm{~mm}$, breadth: $0.23 \mathrm{~mm}$.

Fig. 3. Ogmoconchella aspinata (DREXLER)...

1969-OM-16

42

Carapace, larva $\mathrm{A}-3$, right side, sample $\mathrm{M}_{21}$.

Length: $0.38 \mathrm{~mm}$, height: $0.24 \mathrm{~mm}$, breadth: $0.19 \mathrm{~mm}$.

Fig. 4. Ogmoconchella aspinata (DREXLER)

1969-OM-17

Carapace, larva $\mathrm{A}-4$, right side, sample $\mathrm{M}_{21}$.

The posteroventral spine is broken.

Length: $0.32 \mathrm{~mm}$, height: $0.20 \mathrm{~mm}$, breadth: $0.16 \mathrm{~mm}$.

Fig. 5. Ogmoconchella aspinata (DREXLER).

1969-OM-18

42

Carapace, larva $\mathrm{A}-5$, right side, sample $\mathrm{M}_{21}$.

Length: $0.29 \mathrm{~mm}$, height: $0.18 \mathrm{~mm}$, breadth $0.15 \mathrm{~mm}$.

Fig. 6. Ogmoconchella aspinata (DreXLER).

Carapace, larva $\mathrm{A}-6$, right side, sample $\mathbf{M}_{21}$.

The posteroventral spine is broken.

Length: $0.24 \mathrm{~mm}$, height: $0.15 \mathrm{~mm}$, breadth: $0.13 \mathrm{~mm}$.

Fig. 7. Ogmoconchella aspinata (DREXLER)

1969-OM-20

42

Carapace, larva $\mathrm{A}-7$, right side, sample $\mathrm{M}_{21}$.

Length: $0.19 \mathrm{~mm}$, height: $0.13 \mathrm{~mm}$, breadth: $0.11 \mathrm{~mm}$.

Phot. O. Neergaard Rasmussen. 


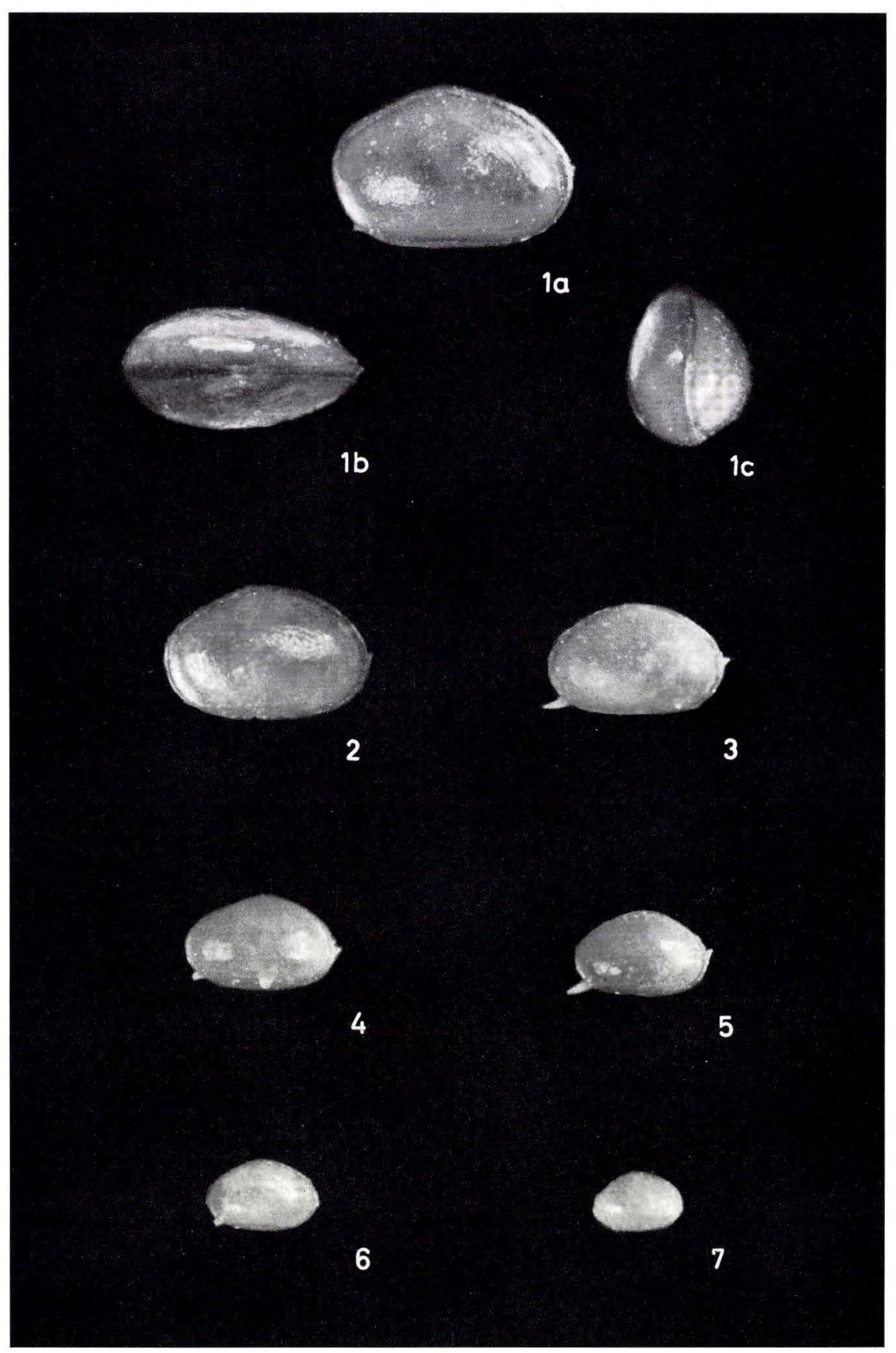


Figs. 1-2. Ogmoconchella aspinata (DREXLER) 1969-OM-23 42 Left valve, + , internal view, sample $\mathrm{M}_{21}$. Length: $0.59 \mathrm{~mm}$, height: $0.41 \mathrm{~mm}$. Fig. 1: $85 \times$.

Fig. 2: The muscle scars, $440 \times$.

Figs. 3-4. Ogmoconchella aspinata (DREXLER) 1969-OM-24 42 Right valve, $q$, internal view, sample $M_{21}$. Length: $0.55 \mathrm{~mm}$, height: $0.34 \mathrm{~mm}$. Fig. $3: 85 \times$.

Fig. 4: The muscle scars, $440 \times$.

Figs. 5-6. Ogmoconchella aspinata (DREXLER) Left valve, larva $A-1$ ( $)$, internal view, sample $M_{21}$. Length: $0.52 \mathrm{~mm}$, height: $0.34 \mathrm{~mm}$. Fig. 5: $85 \times$.

Fig. 6: The muscle scars, $440 \times$.

Figs. 1-6: Scanning electronic micrographs.

Phot. A. Nørgaard Jensen. 

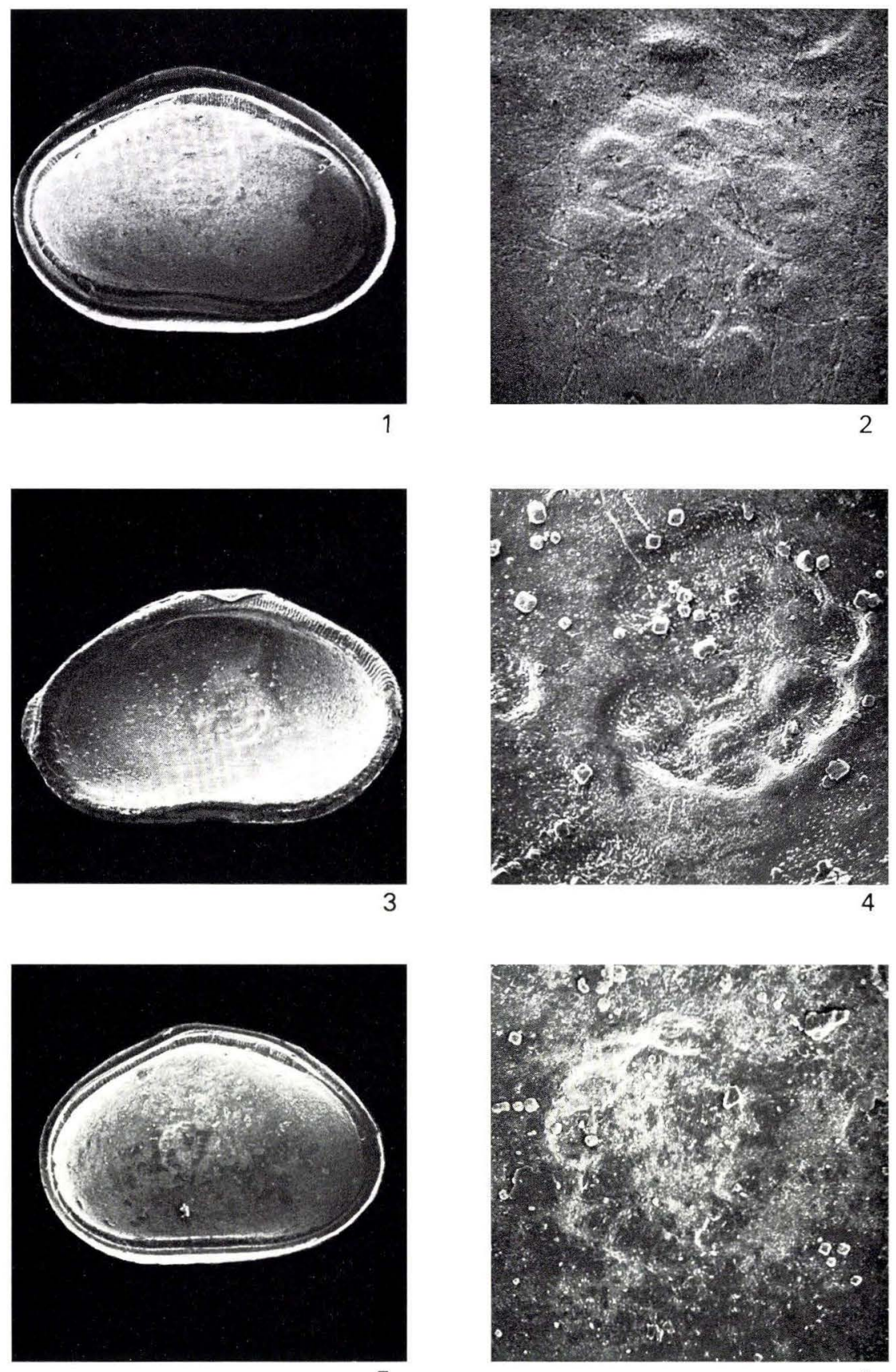


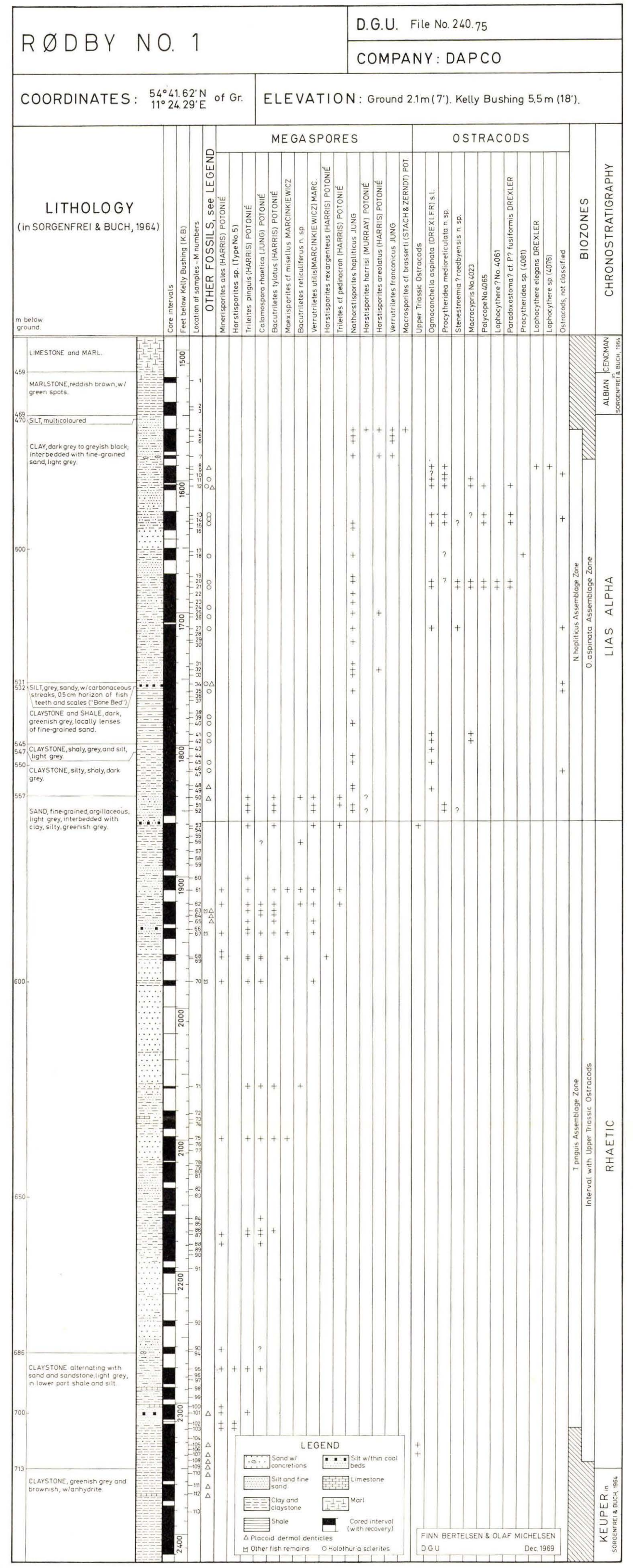

